\title{
VALUE CREATION IN PRIVATE EQUITY
}

A Master's Thesis submitted for the degree of "Master of Business Administration"

supervised by

Univ.Prof. Dr Klaus Gugler

Wolfgang Mayrhofer

0706910 


\section{Iniversität wien}

\section{Affidavit}

I, MAG. (FH) WOLFGANG MAYRHOFER, hereby declare

1. that I am the sole author of the present Master's Thesis, "VALUE CREATION IN PRIVATE EQUITY", 101 pages, bound, and that I have not used any source or tool other than those referenced or any other illicit aid or tool, and

2. that I have not prior to this date submitted this Master's Thesis as an examination paper in any form in Austria or abroad.

Vienna, 22.06.2010 


\section{TABLE OF CONTENT}

1 INTRODUCTION

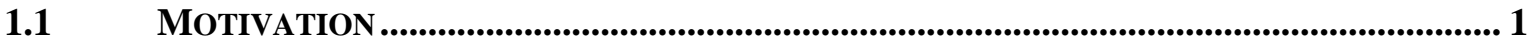

1.2 DEFINITION OF THE RESEARCH STATEMENT _.......................................................... 3

1.3 OUTLINE AND AIM OF THE RESEARCH QUESTION ......................................................... 3

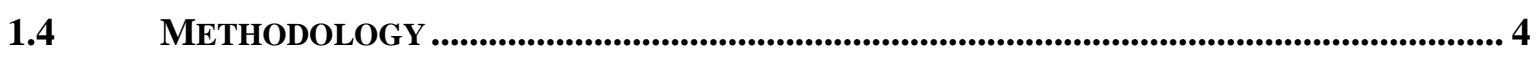

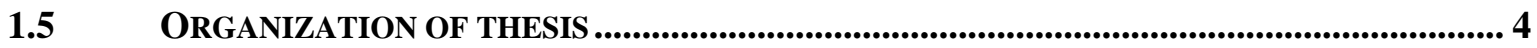

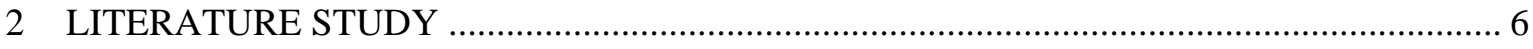

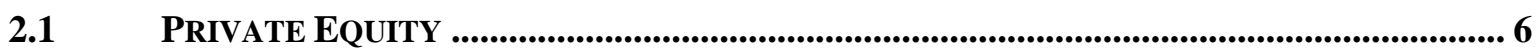

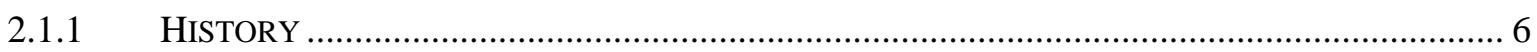

2.1.2 FUND STRUCTURE AND COOPERATION MODELS ........................................................... 8

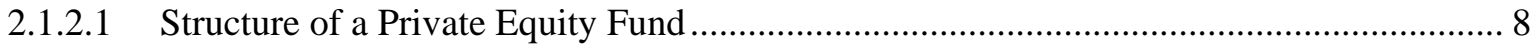

2.1.2.2 Financing Structures and Models in Private Equity ........................................................ 10

2.1.3 PERFORMANCE EVALUATION AND CALCULATION ........................................................... 13

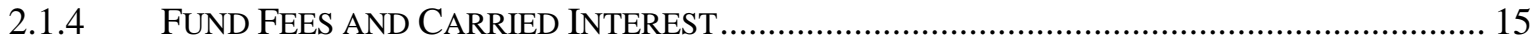

2.1.5 LARGEST PRIVATE EQUITY FIRMS ON A GLOBAL SCALE .............................................. 16

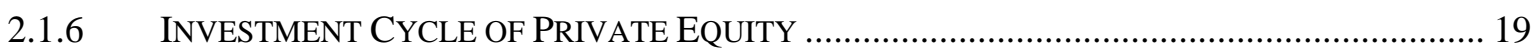

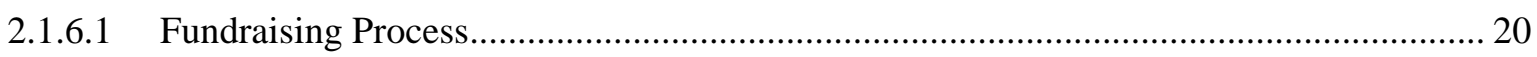

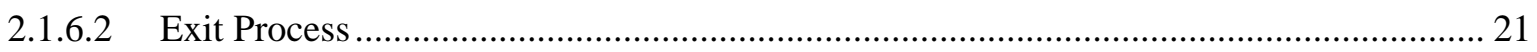

2.1.7 PRINCIPAL-AGENT RELATIONSHIP IN PRIVATE EQUITY ................................................ 22

2.1.8 ECONOMIC CRISIS AND IMPACT ON PRIVATE EQUITY INDUSTRY ....................................... 23

2.2 VALUE CREATION ................................................................................................................. 24

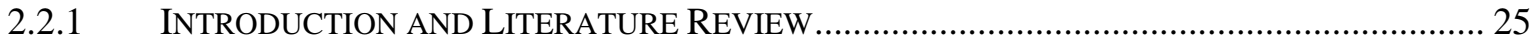

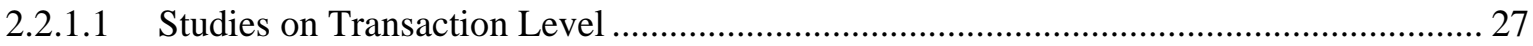

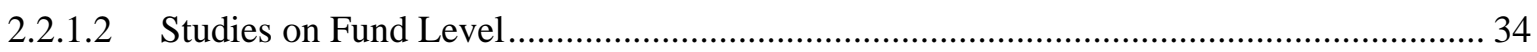

2.2.2 Portfolio Management Models IN Private Equity ................................................. 36

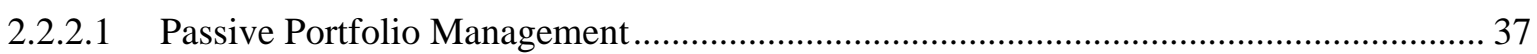

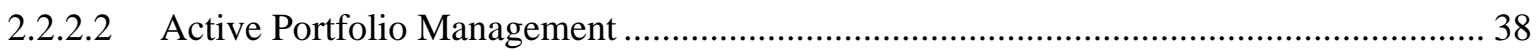

2.2.3 CRITERIA AND FACTORS OF ACTIVE PORTFOLIO MANAGEMENT ...................................... 40

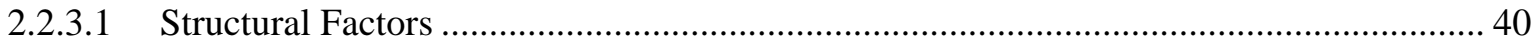

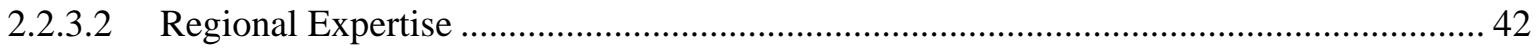

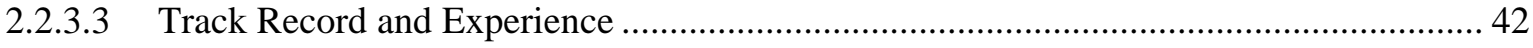


2.2.4 VAlue CREATION By CHANGES IN CORPORATE GOVERNANCE STRUCTURES................. 43

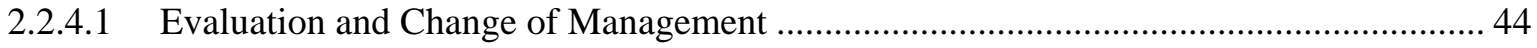

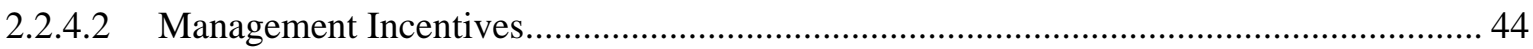

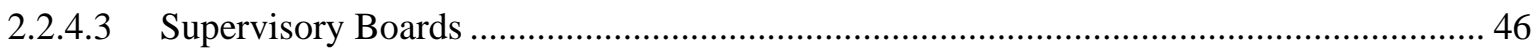

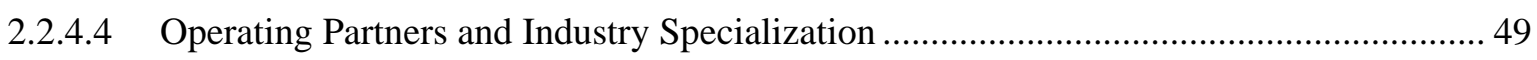

2.2.5 VALUE CREATION BY STRATEGIC AND OPERATIONAL IMPROVEMENTS ........................... 52

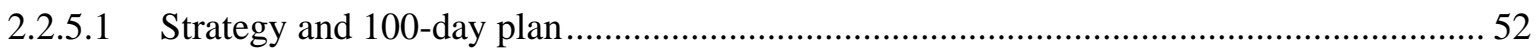

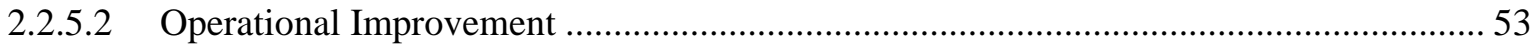

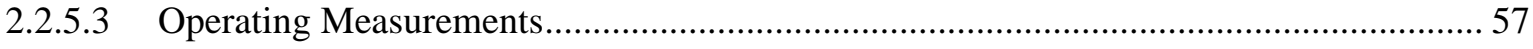

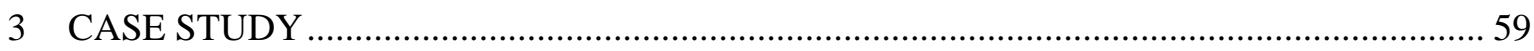

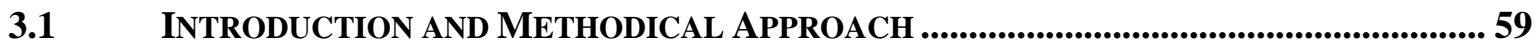

3.2 PRIVATE EQUITY COMPANY DEUTSCHE BETEILIGUNGS AG ........................................ 59

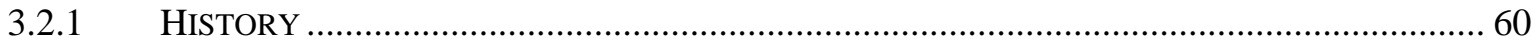

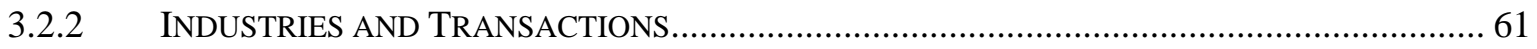

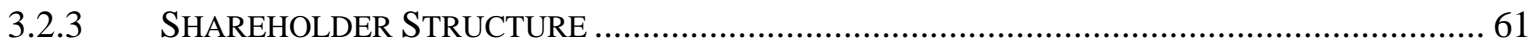

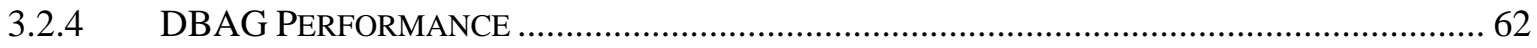

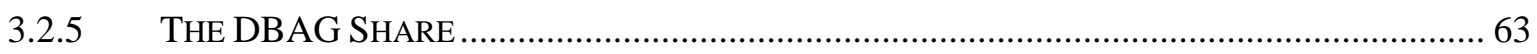

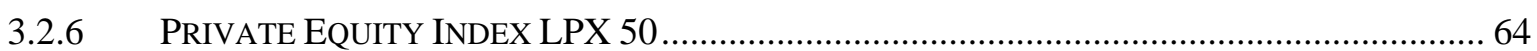

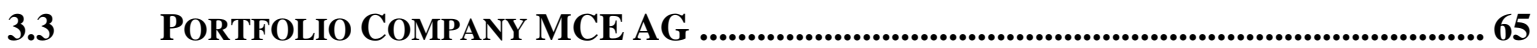

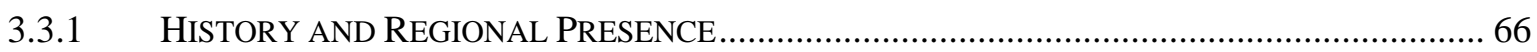

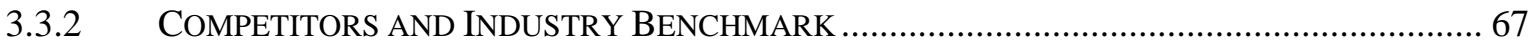

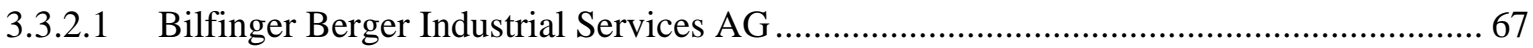

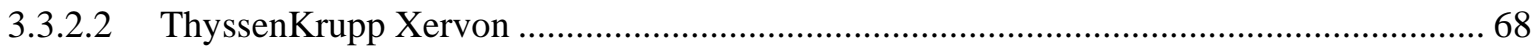

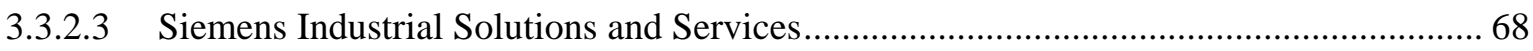

3.3.3 ANALYSIS OF THE ORGANIZATION BEFORE DBAG OWNERSHIP ....................................... 68

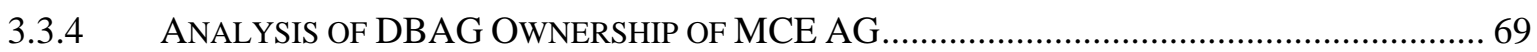

3.3.4.1 Value Creation by Changes in Corporate Governance Structure ...................................... 70

3.3.4.2 Value Creation by Strategic and Operational Improvements........................................... 71

3.3.5 ANALYSIS OF EXIT SCENARIO AND FINANCIAL IMPROVEMENTS ……….......................... 72

PORTFOLIO COMPANY LEWA GMBH .............................................................................. 74

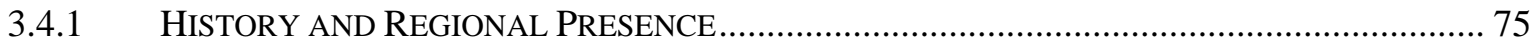

3.4.2 ANALYSIS OF THE ORGANIZATION BEFORE DBAG OWNERSHIP ..................................... 75

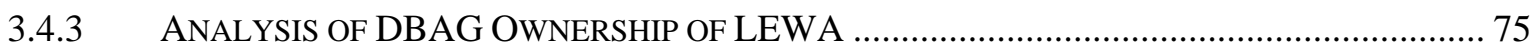

3.4.3.1 Value Creation by Changes in Corporate Governance Structure ...................................... 76

3.4.3.2 Value Creation by Strategic and Operational Improvements.............................................. 77 
3.4.4 ANALYSIS OF EXIT SCENARIO AND FINANCIAL IMPROVEMENTS

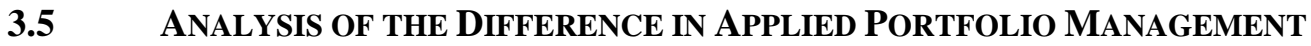

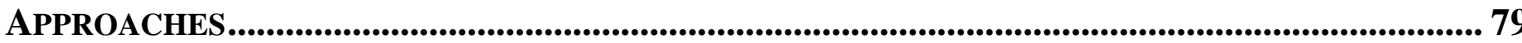

4 CONCLUSION.

82 


\section{LIST OF FIGURES}

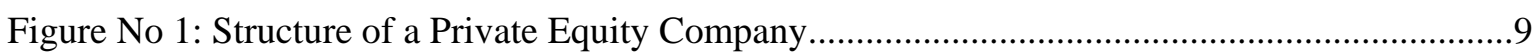

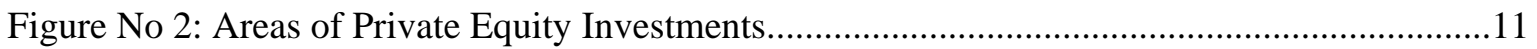

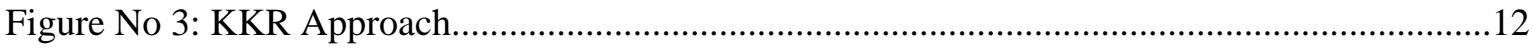

Figure No 4: Typical Acquisition Financing Structure in Private Equity.......................................13

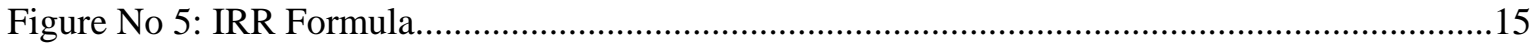

Figure No 6: 1-25 of 50 Biggest PE-Firms according to Capital Raised............................................17

Figure No 7: 26-50 of 50 Biggest PE-Firms according to Capital Raised......................................18

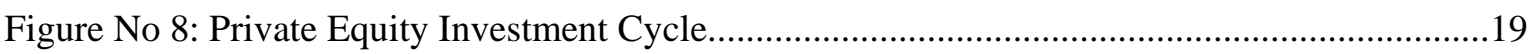

Figure No 9: Overview of Studies on Transaction Level.................................................................27

Figure No 10: Fundamental Value as Main Source of Value Creation..............................................31

Figure No 11: Overview of Studies on Transaction Level...............................................................

Figure No 12: Company Outperformance driven by Active Ownership Practices Deployed in the

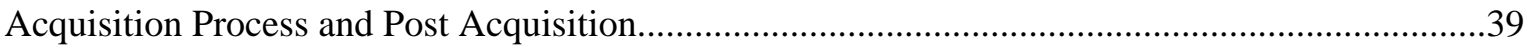

Figure No 13: Decade of Operational Improvement.........................................................................54

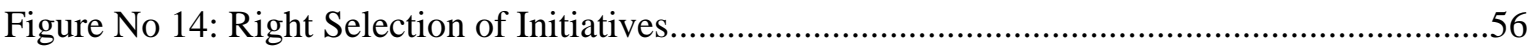

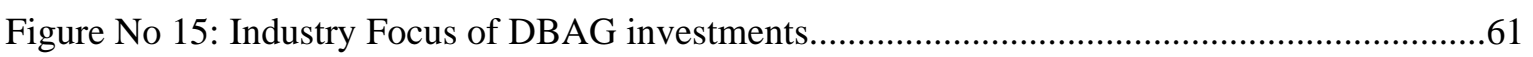

Figure No 16: Transactions by Industry Sectors from Nov 1996 to Oct 2009...................................61

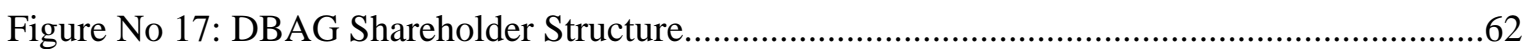

Figure No 18: 14 percent on a 10 year average ROE per DBAG-Share..........................................62

Figure No 19: ROE of DBAG outperforms Other Asset Classes.......................................................63

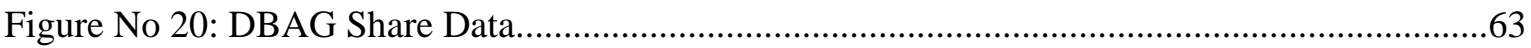

Figure No 21: DBAG Share Performance from 1 Nov 2004 to 31 Dec 2009....................................64

Figure No 22: LPX50® 3-Year Performance April 2007 - April 2010..............................................65

Figure No 23: Regional Presence of MCE AG in CEE.................................................................67

Figure No 24: MCE AG Key Performance Indicators 2006 and 2008.............................................73

Figure No 25: LEWA: Development of Sales in Million EUR........................................................79 


\section{LiST OF ABBREVIATIONS}

\begin{tabular}{|c|c|}
\hline ARD & American Research and Development Corporation \\
\hline BCG & Boston Consulting Group \\
\hline CalPERS & California Public Employees Retirement System \\
\hline CAPEX & Capital Expenditures \\
\hline CEE & Central Eastern Europe \\
\hline DAX & Deutscher Aktienindex \\
\hline DBAG & Deutsche Beteiligungs AG \\
\hline EBIT & Earnings before Interest and Taxes \\
\hline EBITDA & $\begin{array}{l}\text { Earnings before Interest, Taxes, Depreciation and } \\
\text { Amortization }\end{array}$ \\
\hline FCF & Free Cash Flow \\
\hline GP & General Partner \\
\hline HNWI & High Net Worth Individuals \\
\hline IESE & Instituto de Estudios Superiores de la Empresa \\
\hline IPO & Initial Public Offering \\
\hline IRR & Internal Rate of Return \\
\hline KPIs & Key Performance Indicators \\
\hline KKR & Kravis Kohlberg Roberts \\
\hline LBO & Leveraged Buy-Out \\
\hline LP & Limited Partner \\
\hline M\&A & Mergers\&Acquisitions \\
\hline MCE & Machinery, Construction, Engineering \\
\hline NVCA & National Venture Capital Association \\
\hline PEI Media & Private Equity Media \\
\hline $\mathrm{PE}$ & Private Equity \\
\hline
\end{tabular}


SBIC

SME

SWF

TU Munich

UK

U.S.

VC

WACC
Small Business Investment Companies

Small \& Medium Enterprises

Government-Owned Sovereign Wealth Funds

Technical University of Munich

United Kingdom

United States

Venture Capital

Weighted Average Cost of Capital 


\section{AbSTract}

Since Private Equity implies that information is kept rather private, there is a lack of general knowledge about this industry, and research data is hard to access. Nevertheless, the question of how value is created in Private Equity is not only interesting to investigate but also crucial to assess the performance of Private Equity as business model and asset class. The Private Equity business model is often perceived to generate extremely high returns by financial (debt) leverage and other financial engineering models. Due to the crisis and the consequently changed credit markets, the leverage model cannot longer be executed to the same extent as before the crisis. In this work, a distinction is made between operational and financial value drivers and, therefore, the central research investigates

\section{“How Active Portfolio Management Creates Value in Private Equity”.}

Until today, only few scientists have done research and publications on this topic. Relevant studies - discussed in the literature review - are focusing on value creation on either transaction level or fund level. However, none of the present publications provides a detailed overview of those factors that influence the ability to create value in portfolio companies. Therefore, this work explains the ideal organizational setup of Private Equity firms and deepens into value creation drivers (for portfolio companies) such as the

Operating Partner model, possible changes in corporate governance structures and operational improvements. Additionally, comparisons are drawn between value creation in public listed companies and portfolio companies of Private Equity funds.

The case study differentiates between two different portfolio management models applied by one German Private Equity firm. In one of the portfolio companies, an active investor approach is applied whereas in another portfolio company a rather "old-school” passive investor approach is employed. Besides the ownership model, the case study also analyses various applied value creation drivers and the successful exit scenario. Literature and financial results of the case reveal that active portfolio management creates higher returns to Private Equity investments and builds sustainable value in portfolio companies. This comprehensive work on Value Creation in Private Equity can be understood as a macro study on existing knowledge and as guidance for employment of value creation drivers in Private Equity. 


\section{INTRODUCTION}

“Once you buy a company, you are married.

You are married to that company.

It's a lot harder to sell a company than to buy a company.

People always call and congratulate us when we buy a company.

I say, “Look, don't congratulate us when we buy a company,

Congratulate us when we sell it.

Because any fool can overpay and buy a company

as long as money will last to buy it.

Our job really begins the day we buy the company,

and we start working with the management,

we start working with where this company is headed."

(Kravis, 2004)

\subsection{Motivation}

Academic literature covers many corporate-finance aspects of Private Equity (PE) such as the leverage-effect, various possible calculation models of Internal Rates of Return (IRR), and performances on fund level and transaction level. Very little research is done about how PE-firms manage their portfolio in practice, and how value is created by operational improvements and corporate governance changes during the holding period. The main problem of deepening the academic research about value creation in Private Equity is that the concept is quite "private" and it is, therefore, hard to access data and even harder to receive - besides quantitative data - relevant qualitative information about real-life applications of value drivers. Also well-known academic researcher in this field like Achleitner (2010) from the TU Munich confirms the given limitations "The academic discussion of value creation in Private Equity is still in its infancy. There is a lack of sufficiently detailed data to perform these analyses. The question of how value is created in private equity transactions is essential for evaluating this asset class.” 
Nevertheless, it can be observed that the PE-industry is undergoing essential changes. That is not only due to the current economic crisis, which has a strong impact on debt financing and value adjustments of portfolio companies, but also due to more demanding capital providers. Investors behind PE-capital have become more rigorous about which companies PE-firms acquire and what improvements are made in their portfolio companies. Additionally, the so called “credit-crunch" makes it very difficult to acquire companies applying the Leveraged Buyout (LBO) model using high debt and just little equity. Before the current crisis, and especially during the eighties and nineties, enormous financial value was created by highly leveraged buyouts in terms of tax-driven benefits. To acquire the same number and size of companies as a PE-fund, the new situation requires raising more money since less debt capital is available. The active ownership approach, which is an alternative to value creation by financial leverage, has evolved within the last few years. Value in portfolio companies should ideally be developed by operational improvements and by improved corporate governance structures.

In the early days of the PE-industry and still now, PE-firms are dominated by former investment bankers who are strong in financial engineering but often lack relevant industrial and operational expertise. Since the general trend obliges Private Equity to move towards a stronger industry focus and towards operational improvement in portfolio companies, the whole personnel setup of PE-firms is in the process of adjustment. Literature and practice suggest that PE-firm should ideally consist of one third bankers, one third industrial experts and one third management consultants. Such a team constellation would cover the requirements of an entrepreneurial active ownership approach towards PE-portfolio companies. Not only the organizational setup is of importance, but also the time PE-professionals and Operating Partners spend with the portfolio companies. The 100-day-plan right after the acquisition as well as the right strategy plan and selection of adequate management are of utmost importance to bring portfolio companies forward. Studies conducted by Klier, Welge and Harrigan (2009) by interviewing managers of the 60 biggest PE-firms show that active PE-investors perform better than rather passive PE-investors. In their work they differentiate between two types of portfolio management models in Private Equity namely active ownership (active investors) and passive ownership (passive investors). The following hypothesis investigates the relation between portfolio management models used in Private Equity and its impact on Value Creation. 


\subsection{Definition of the Research Statement}

\section{“How Active Portfolio Management Creates Value in Private Equity.”}

The focus of this research is primarily on how value can be created by active portfolio management of PE-portfolio companies.

Beside this central research question of the paper, further features and characteristics of Active Portfolio Management are discussed. A broad introduction into the industry of Private Equity and a deepening literature review of studies about "Value Creation” enables to obtain a broader coverage of the topic leading to a get deeper notion of Private Equity and Value Creation.

\subsection{Outline and Aim of the Research Question}

\section{Why research question is important / interesting?}

Science is not only searching for true conclusions and giving evidence but rather for providing true and worth-knowing declarations. An insight, which is only true but not worth knowing is not of interest to anybody (Tenbruck, 1981). The hypothesis and the conclusion of this paper should help to get new insights into the relation between Active PE-investors and their impact on Value Creation. My thesis that active portfolio management in Private Equity creates - on average - more value than passive investment should be affirmed by existing literature and by the presented case study.

Existing studies do only partly answer my research question. Various drivers and factors of value creation are explained and tested in the scientific community, yet, a complete overview is missing. This work aims at providing an overview of existing studies about value creation in Private Equity as well as explaining possible improvements in terms of operations and corporate governance.

Many scientists such as Acharya \& Hahn (2009); Achleitner (2010); Liechtenstein (2008); Groh \& Gottschalg (2008); Guo, Hotchkiss \& Song (2007), Kaplan \& Schoar (2005); Kaserer \& Diller (2005) have measured value creation either on transaction or fund level. It is not surprising that their results are all different from each other due to the fact that different samples with different time horizons cause various outcomes. 


\subsection{Methodology}

After I had stated the research question, I conducted telephone interviews with various PEmanagers and Fund-of-Funds managers from UK, Germany and Austria in order to receive approval that the suggested hypothesis is of relevance. The general response was that value creation by operational improvement and by corporate governance changes is a current trend, and even an increasing requirement for investors to commit capital to PE-funds. Some PE-companies have already adjusted to the new standards, yet, many firms in Private Equity have not changed their strategies and organizational structures. These companies will face more and more problems to raise capital for their funds since capital providers do accurately investigate how PE-firms manage their portfolios.

The thesis is built up by identifying and analyzing relevant state-of-the-art theories, which serve as background knowledge on the notion of the PE-industry and the significance of value creation. The main part of the paper - chapter two - is an analysis of how value can be created in the context of active portfolio management. In chapter three, a case study is presented to show how value creation can be applied related to real life.

Deutsche Beteiligungs AG (DBAG), a German based stock listed PE-company with a long history, turned out to be a very good example for a passive investor that is changing towards an active investor model. The case study investigates how DBAG acted as a majority owner in two of their portfolio companies. These two companies - MCE and LEWA - that used to be in the DBAG-fund until 2009 - are explored in terms of how they performed before the investment of DBAG, and how they developed with DBAG as new owners. A financial performance comparison between entry and exit of DBAG is conducted, and qualitative ownership behaviour is described. In the analysis of the case study significant effects of PE-ownership on the two portfolio companies are explained. Additionally, the exit scenarios of both portfolio companies are illustrated and - to a certain extent - how much profit DBAG has realized with these two deals.

\subsection{Organization of thesis}

The review of literature chapter moves gradually from the very general to the very specific regarding explanations and theories about value creation. It starts by explaining Private Equity, its history, players in the market, its mechanism and an overview of biggest player 
in the industry. Then it goes down to value creation and provides an overview of existing studies in this field followed a setup of value creation drivers that could be applied. The empirical chapter presents a case-study analyzing a German PE-company and how it applied different portfolio management approaches in two of their portfolio companies. It also presents the outcome of the study and explains the way conclusions are drawn. The reasoning leading to the results is described carefully. The last chapter discusses the outcome of the paper and explains limitations and problems of the study. Furthermore, some suggestions for future research in that field are given. 


\section{LITERATURE STUDY}

The following literature study is built up in two main parts. The first part covers Private Equity in a very general and descriptive way, and the second part is about value creation in Private Equity analyzing existing studies in this field.

\subsection{Private Equity}

Before going into details about Private Equity and history, players and financing models of this industry, it is necessary to explain how the term Private Equity can be defined.

Private Equity can be described as ownership in a corporation that is not publicly-traded on the stock market. Therefore the concept is about investing in privately held companies. Most of the time, private equity investors are institutional investors - such as Private Equity firms - but also high net-worth individuals who have a large amount of capital to invest are active in this field. Private Equity is usually held for a longer period of time than shares on the stock market. Since it provides access to possible high amounts of capital very quickly, gaining access to Private Equity might be useful when a company needs growth capital or is in danger of bankruptcy. (Financial Dictionary)

\subsubsection{History}

During the big rise of private equity in the 1980s, PE-firms became famously known as “corporate raiders” (Anders, 1992). Not only caused by famous films such as "Barbarian at the Gate”, "Wall Street”, etc., in which PE-managers always became immensely rich by greedy capitalistic behaviour, the PE-industry had a very bad image. Back then it was only connected with financial plays, cost-cutting and the stripping of assets. Since then, the PEindustry has significantly changed due to the fact that the industry has matured and many successful PE-companies become active and responsible investors in their portfolio companies. (Klier, Welge and Harrigan, 2009) In the late nineties, when the internet bubble was at its peak, Venture Capital (VC) - as one form of Private Equity, in which PEcapital is invested in start-up companies - gained attention. The reason behind is that many famous internet companies - such as Apple, Intel, UPC, Google, Amazon, Skype and many others - made their companies grow with investments from VC-firms. 
In order to understand the big picture of the historical backgrounds and circumstances that has made the PE-business grew, one has to look back the roots. This part on PE-history is based on literature by Loos (2005); Fenn, Liang et al. (1996); Ibbotson, Sindelar et al. (1988).

The story of Private Equity starts with developments in the United States during the second half of the 20th century. Investments in private firms have always been there since the industrial revolution, yet, the first professionally managed PE-investments in the U.S. date back to the formation of the American Research and Development Corporation (ARD) in 1946. The founders of ARD wanted to create a private institution attracting institutional investors that provide capital and managerial expertise to acquired businesses. Since there was short supply of PE-capital in the 1950s, the U.S. Congress passed a new law (Small Business Investment Act of 1958) enabling the foundation of Small Business Investment Companies (SBICs). These SBICs were private corporations that provided professionally managed capital to risky companies, whereby they were allowed to add loans to the private capital, so certain tax benefits could be realised. Throughout the 1960s, PE-managers had gained valuable experience but only modest personal reward for what they did. Consequently, a significant number of VC-Limited Partnerships came into existence in order to address the compensation issue. Limited Partnerships started to attract new and more sophisticated investors compared to the publicly traded SBICs. In the early 1970s, organized Venture Capital financing became recognized as an industry and in 1973 the U.S. National Venture Capital Association (NVCA) was formed. The formation of the new type of PE-partnerships was decelerated by other factors leading to slow investments for nearly a decade. One major reason for that was the weak state of the IPO-market in the mid-1970s. During 1973-1975, there were only 83 IPOs in comparison with 1969 when 548 IPOs took place. Additionally, there was a strong recession, consequently weak stock markets slowed investment and acquisition activities of corporations. Also capital gains tax rates had increased strongly in 1969, so that employee stock options became less attractive. Besides that there was a general shortage of qualified and entrepreneurial managers able to restructure and run acquired businesses. In the end of the 1970s, interest rates were decreasing preparing the way for an explosive growth of Private Equity in the 1980s. Slowly PE-capital was more and more used for acquisitions of more established companies, which led to the rise of Leveraged Buyouts. The most significant change for the PE-industry in the U.S. was a decision of the U.S. Department of Labour changing the 
interpretation of the "prudent man" provision governing pension fund investing. The U.S. Labour Department decided that investments in Private Equity and Venture Capital partnerships are permitted. That decision led to an enormous inflow of capital to PEhouses. The boom of Private Equity during the 1980s was enhanced by further regulatory changes. The U.S. Congress made a decision concerning official registration for investment advisers. The registration under the "Investment Advisors Act" was not necessary at all when advisors have fourteen or less clients. The PE-industry took advantage of this new law by restricting the number of Limited Partners to less than fourteen. Nevertheless, very soon another act came into play redefining PE-partnership as business development companies, therefore, becoming exempted from the Investment Advisor Act.

In Europe, Private Equity only started making serious progress during the 1990s. Structural and legal changes with respect to pension fund and insurance company regulations were established only within the last ten years. These changes allowed a liberalization of investment choices to institutional investors. According to the European Commission's Expert Group Report on Private Equity (2006), the PE-industry on continental Europe is still maturing. The PE-industry plays an essential role in mobilising private capital to invest in private enterprises for further growth and development. In Europe, there is still a need for a better comprehension of how Private Equity as an industry is organised and how it works. To conclude this chapter, one has to be aware of the fact that - even though PE as an asset class has become a major player in the financial industry and has an enormous impact on the economy of a country - only very few people do not what the PE-business is about. Even business people such as entrepreneurs and managers - for whom PE-investors could be of potential importance - do know only little about this asset class.

\subsubsection{Fund Structure and Cooperation Models}

\subsubsection{Structure of a Private Equity Fund}

Before explaining how a typical PE-fund structure is set up, the general difference between an Evergreen Fund and a Closed-End Fund needs explanation. Closed-End funds, as their name suggests, have a certain expiration date when the companies in the fund are to divest and the fund is to be dissolved. Besides some exceptions PE-houses usually use closed-end 
funds. The usual process includes the following steps. First, a PE-firm establishes a fund, then it raises money until a certain deadline, invests in companies, sells the companies after a certain time, distributes the initial capital plus realised gains to the capital providers and dissolves the fund. Within a PE-house consequent funds are then to be established or possibly - other funds with a different industry focus exist parallel. In an evergreen-fund, money is raised, invested, divested and redistributed on a continuous level. Investments in PE-funds are illiquid meaning that investor's access to invested capital during the lifetime of the fund is not possible. Since the investor's capital is not accessible, an element of risk is connected with PE-investments. The investor can not choose to re-allocate his invested capital into other assets during the investment period. This additional risk in Private Equity is called illiquidity discount.

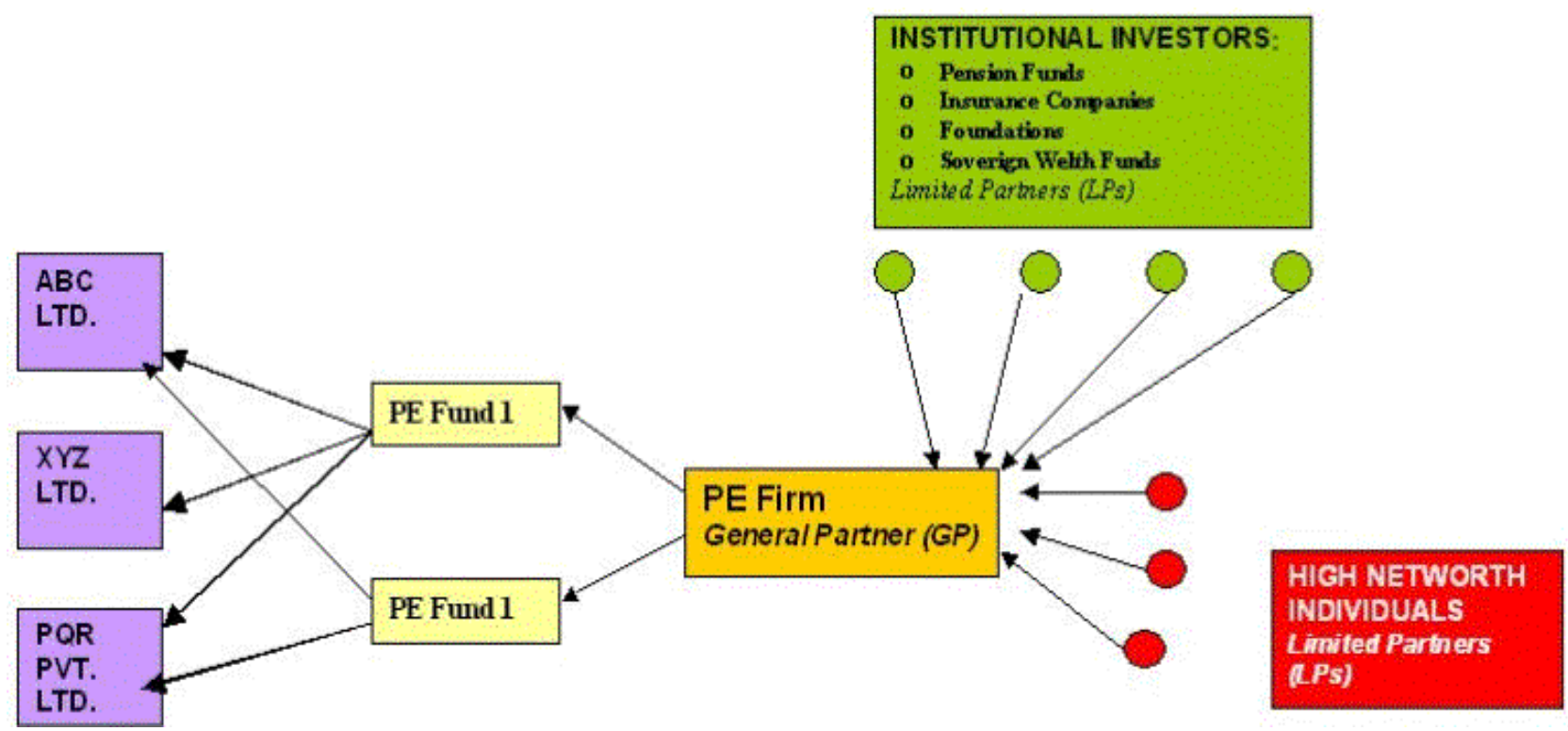

Figure No 1: Structure of a Private Equity Company

(according to Renewal, 2008)

In this part of the chapter, which is based on literature from Gompers and Lerner (1999) and Mehta (2004), the structure of a PE-company is explained by the usage of Figure No 1. The most common legal fund-structure used in Private Equity is the limited partnership (yellow boxes in Figure No 1). Usually institutional investors (green box in Figure No 1) are named Limited Partners (LPs) allocating their capital to the PE-firm or directly in funds, which are managed by the PE-firm (also called General Partners (GPs)). The lilac boxes in figure No 1 represent portfolio companies of the funds. The arrows show that cross holdings are possible meaning that a portfolio company is held by different funds. 
Other possible investors in Private Equity are High Net Worth Individuals (HNWI) listed in the red box in Figure No 1. LPs cannot participate in the day-to-day decision-making processes of the funds. Besides having a seat in the investment committee, which is not often the case, LPs are not able to directly control the actions of the GPs. PE-firms can be seen as economic agents with full information about the activities and performances of the funds they manage, whereas LPs are the owners of the invested capital in a fund. Between investors and PE-firms, there are usually limited partnership agreements including contractual compensation features to maximize efficiency and to minimize the informational asymmetries between LPs and GPs. The typical PE-limited partnership agreement is a long-term commitment for a period from 8-13 years, whereby terms are renegotiated very rarely.

\subsubsection{Financing Structures and Models in Private Equity}

This chapter explains various forms of PE-models since there are financing constructions in which PE-funds are involved without necessarily playing the main ownership role. This chapter does also provide an explanation of the Leveraged Buy-Out (LBO) structure since this form of acquisition financing is - as mentioned before - a very important part of the PE-business model. It is characteristic for PE-deals to be highly leveraged meaning that - besides allocating the capital of LPs - a high percentage of debt is used to acquire companies, which is then paid back by the acquired company. According to Loos (2005), a LBO can be defined as a transaction in which a group of private investors, typically including management, acquire a significant and controlling equity stake in a public or non-public corporation or a corporate division, using significant debt financing, which is raised by borrowing against the assets and/or cash flows of the target firm. LBO as a common form of takeovers has evolved in the 1980s, and since then PE-firms focused on making this type of investment by using debt and PE-capital.

Practice has shown that the group of private investors consist of any combination of a leveraged buyout firm, management or another corporation like pension funds. The processes of LBO require a special skill-set of PE-professionals since the investment focus lies on a different stage of the life cycle of a company. Private Equity investments are divided into five broad categories - as outlined below - whereby LBO is mostly applied at the most mature stage of a company. 


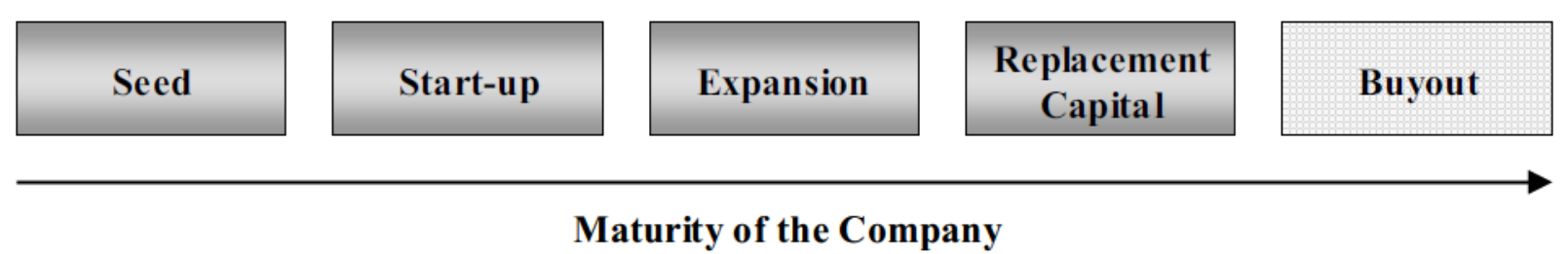

Figure No 2: Areas of Private Equity Investment

(according to Loos, 2005)

LBOs are also well explained in studies of DeAngelo, and Rice (1984), and Muscarella (1990) saying that LBOs have become an important method of corporate restructuring and profitability improvement. The most common method of an LBO has the following characteristics in practice. A PE-firm identifies a target firm that it wants to acquire. After the investigation if the target company can be acquired, PE-managers set up the financing by talking to several large lending institutions to syndicate a loan for the acquisition. This so called "Bridge Finance" includes a combination of senior and junior debt like credit facilities, bank debt, mezzanine or high yield. Additionally, PE-managers talk to the management team of the target company in order to make them share equity ownership of the new entity. More structured finance details are illustrated and explained in the context of figure No 3.

LBOs can be further classified into Management Buy-outs (MBO) and in Management Buy-In (MBI). In the case of MBOs the current management makes arrangements with outside providers of both debt and equity capital to take control of the company from its previous owners. In the case of MBIs an external management team is funded by outside investors to take over control of a given target company. In both cases the investor aims at acquiring a significant portion for majority control in the target firm, which involves a change of ownership (Hite and Vetsuypens, 1989). Kravis (2004) affirms the importance of LBOs saying that every PE-player uses the tool of leveraged finance "Our success in building businesses by leveraging our flourishing capital markets has led to increased competition from traditional private equity investors as well as from outside the industry. The pure skill of increasing leverage to drive returns has been commoditized and is no longer a distinguishing factor in the private equity world". 


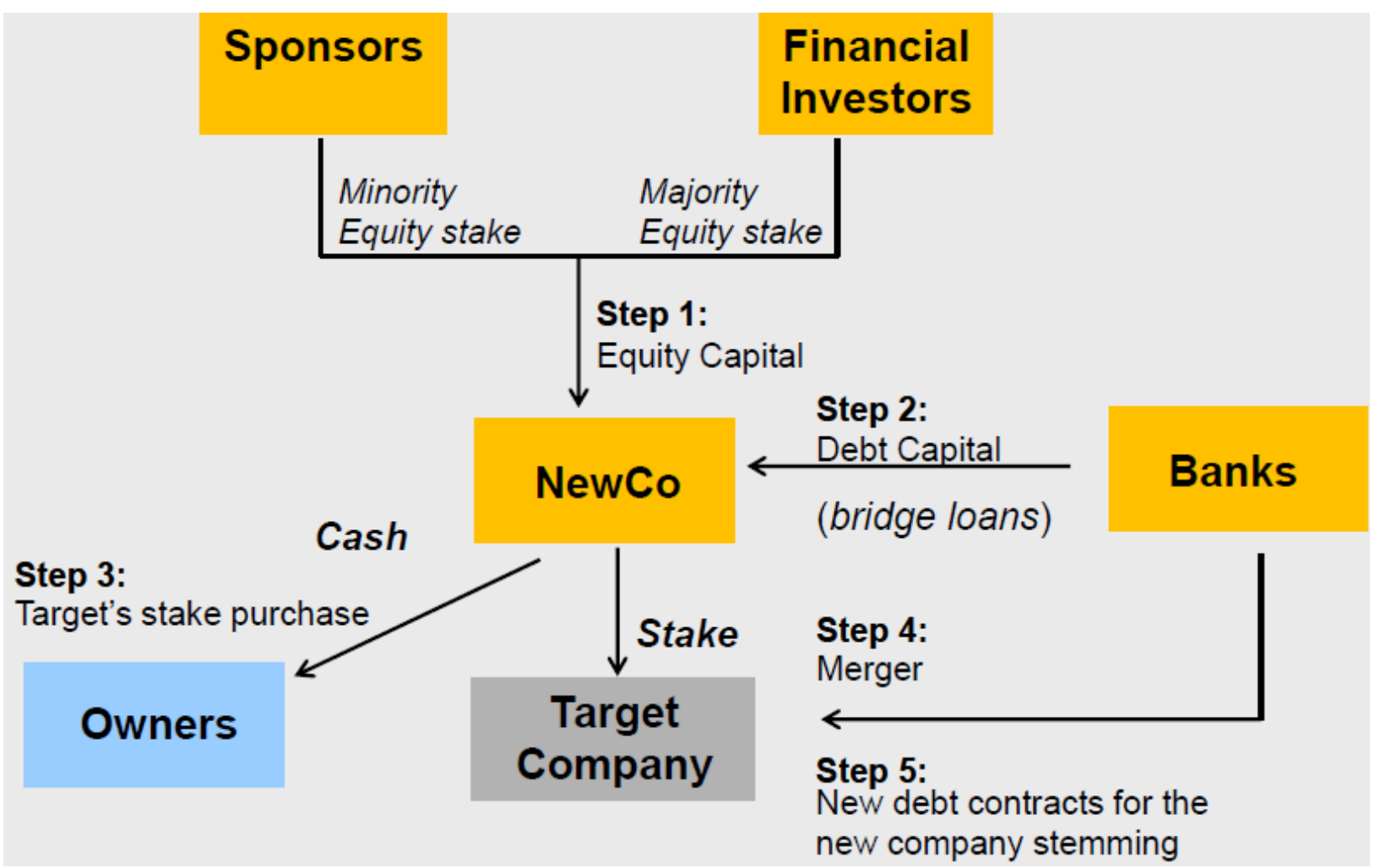

Figure No 3: KKR Approach

(according to Vincenzo Capizzi, 2005)

Figure No 3 clearly illustrates the method and most important five steps of acquisition financing, which is also called the "Kravis Kohlberg Roberts (KRR) approach" since they invented the model. This model is often used by PE-houses, either in LBOs or in less highly leveraged acquisitions. The first step (step one) of the KKR approach involves that equity holders such as PE-firms, funds, managers or other institutions allocate capital into a newly formed - here named - "New Company” (NewCo).

In step two, NewCo is additionally equipped with debt capital (usually through short-term loans or Bridge Finance) from a syndicate of banks. The loan is often secured by assets or shares of the target company as collateral. Since the loan can temporarily exceed the amount needed, flexibility in the form of bridge financing by the banks is needed. In step three, NewCo acquires the whole equity base or a majority equity stake of the target company by buying out former owners in cash. In step four NewCo merges with the target company in the form of an upstream or downstream merger depending on the local legal requirements. Last step (step five) includes that NewCo's debts are transferred to the acquired company, whose cash-flows then become the only source of the financial flows required to remunerate banks and other investors. Additionally, the short-term debt 
contracts originally obtained by NewCo are then substituted with new long-term and secured contracts entitled to the new entity stemming from the merger. Figure No 4 shows a typical acquisition financing structure in Private Equity including different kinds of financing and their features. The presented numbers have slightly changed due to the last financial crisis. The equity part of a transaction is, nowadays, rarely less than 30 percent.

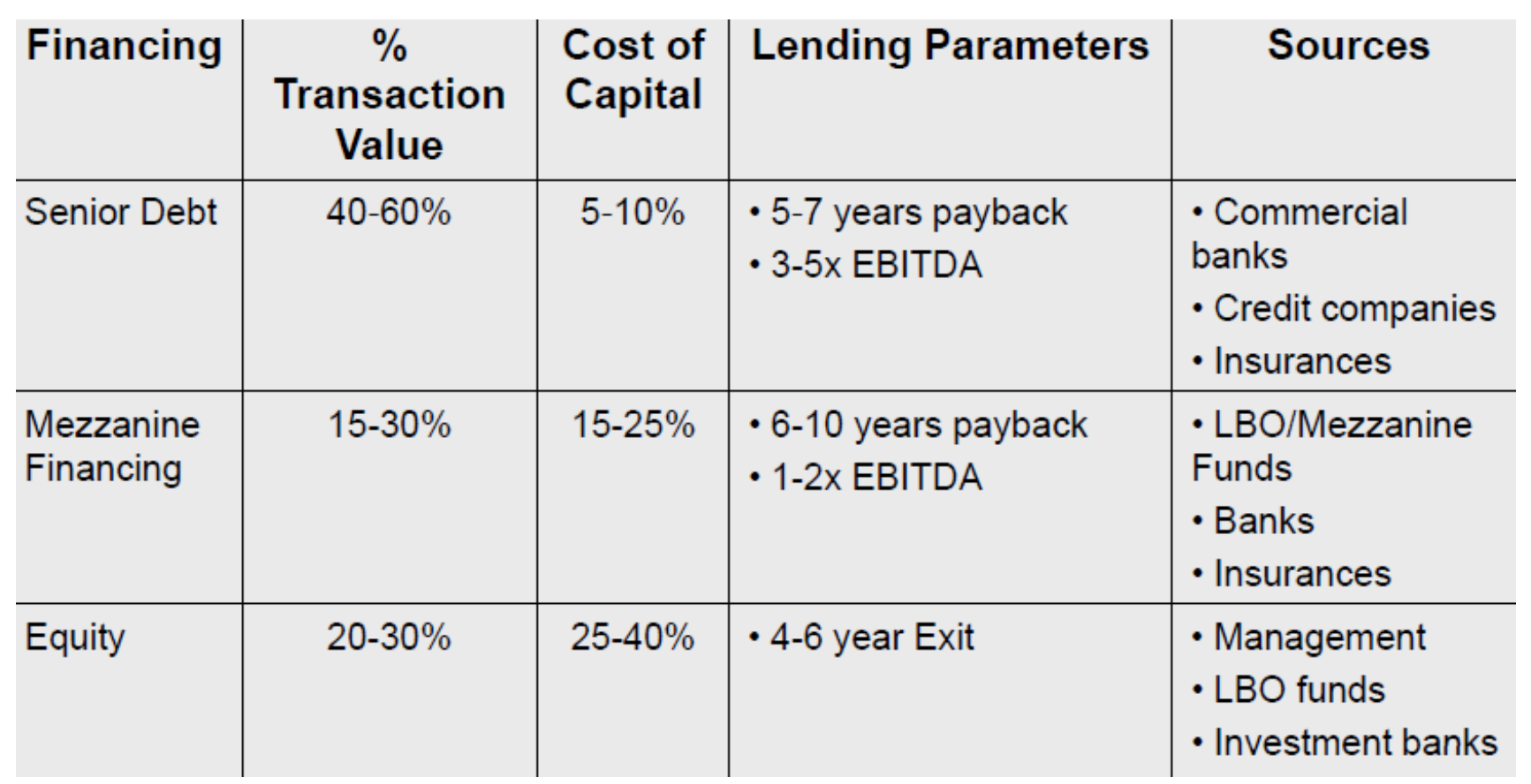

Figure No 4: Typical Acquisition Financing Structure in Private Equity

Table compiled by author

\subsubsection{Performance Evaluation and Calculation}

This chapter based on studies by Loos (2005) and Nikoskelainen (2007) provides an overview of evaluations and calculation methods of PE-transactions. After a full exit from the investment it is the evaluation of the PE-ownership performance that counts. Only the evaluation after exit shows the complete picture of value creation within a PE-deal. Although PE-houses continuously apply value creating measurements within the whole holding period, the extent of the realised value creation is only revealed after the investment-exit and capital distribution to LPs. Nevertheless, PE-firms frequently have to report hypothetical returns of their unrealized investments - according to current market valuation - over the holding period. That is especially the case during new fundraising actions. The unrealized deal returns are based on the assumption that a certain portfolio 
company would normally - if sold at any given time - be evaluated according to the industry peer group. In order to measure the long-term performance impact of PEownership, the internal rate of return (IRR) is used as the key metric. Literature - Kaplan and Schoar (2005), Ljungqvist and Richardson (2003) - suggests that IRR is the most commonly used metric of the return on PE-investments. Theoretically, the IRR-method compares the value of the equity stake of the PE-firm at exit against the initial equity investment. It should be mentioned that this simple method might contain flaws. In some cases - depending on the size of the investment and firm - significant intermediate cash flows such as extraordinary dividends are already taken out of the portfolio company within the holding period. The IRR-calculation often is constructed in a way that it includes a discounted cash flow analysis discounting all cash inflows and outflows to owners. Nowadays, it is common practice in Private Equity to calculate and report deal IRRs on the basis of all cash in- and outflows and their exact timing. The problem is that exact cash in- and outflows are not always adequately documented by General Partners in their private purchase memorandum. For a better understanding of PE-performance evaluation, the exact calculation of IRR needs to be explained. The first calculated metric of return in a PE-transaction is the gross internal rate of return on invested capital by the fund. It is usually the case that PE-funds report both gross and net IRRs both based on actual cash flows. The gross IRR is the actual return on a defined investment made by the General Partner, whereas the net IRR represents the actual distribution to the investors of the PE-fund.

In the net number the fund management fees as well as carried interest is already excluded. Net IRR representing the profit share of the General Partner on a defined transaction is commonly set around 20 percent as average PE-industry standard. Gross IRR is normally also used for comparison analysis of actual deal performance with public market industry performance for a given investment period. It also serves for a breakdown and analysis of the determinants of gross IRR value creation. However, this work is not designed to evaluate the quantitative elements of gross IRR. The case study in the empirical part of the thesis is based on enterprise values of entry and exit points. Applied value creation drivers are explained but it is not possible within this work to break down value creation drivers into contributors of gross IRR. The following IRR formula presented in Figure No 5 is the basis for gross IRR-calculations and can be further extended. 


$$
I R R=\left[\frac{\text { Equity Value }_{\text {Exit }}}{{\text { Equity } \text { Value }_{\text {Entry }}}^{(1 / \text { Holding Period })}}-1\right.
$$

Figure No 5: IRR Formula

(according to Loos, 2005)

Equity Value at Exit = Amount of total realized and unrealized value at time of exit.

Equity Value at Entry = Equity amount invested by General Partner at time of entry.

Holding Period $=$ Date of exit minus date of acquisition, expressed in years .

\subsubsection{Fund Fees and Carried Interest}

Gompers and Lerner (1999) conducted a study showing that compensation numbers are relatively homogeneous across PE-partnerships. PE-houses generally receive a fixed annual payment - called management fee - of about 1.5 to 2.5 percent of the fund's total committed capital in order to cover daily operations in the PE-firm and costs of the portfolio companies including Operating Partners. The majority of the PE-firm's compensation typically comes form of a variable payment - called carried interest - in which the GP shares a certain percentage of usually 20 percent of the profits of the fund after the initial capital is returned to the capital providers (Mehta, 2004). Research of Gompers and Lerner (1999) reveals that profit shares are higher for older and larger PEhouses that show a constant above average performance.

The performance-based incentive eliminates economic agency problems by aligning interest of the PE-house to execute appropriate actions in managing the fund and the portfolio companies in the fund. According to Covitz and Liang (2002) the carried interest can also limit excessive risk taking, which could result in lower overall profits for the fund, and consequently lower carried interest. The carried interest pay also provides an excellent incentive for PE-firms to invest reasonably so that capital is primarily returned with profits to capital providers because only then PE-firms also make their share of profits. As Mehta (2004) states, the typical carried interest structure can also be seen as a call-option on the value of the fund. From this perspective, the carried interest provokes PE-investors to increase the riskiness of their investments so that the value of their call option increases. It has become common practice that Limited Partners require PE-firms to achieve a certain 
minimum hurdle-rate - also named preferred return - before taking their 20 percent share of the profits. The most common hurdle rate is 8 percent (of the initial capital provided by LPs) representing the annual compounded return that PE-funds must provide for their investors. Only when PE-funds meet this return target they are allowed to take their carried interest from the upside profits of the fund. As common sense and findings by Covitz and Liang (2002) suggest, PE-firms are always very concerned with their variable compensation structure containing a very high upside and downside potential.

\subsubsection{Largest Private Equity Firms on a Global Scale}

The updated 2009 ranking of the top 50 PE-firms worldwide is published by Private Equity International (PEI) Media and is based on the amount of PE-direct-investment capital raised over a five-year time horizon. Since PE-companies are continuously in the process of raising, investing and distributing their PE-funds, the only size measurable is the amount of raised capital. Other values that could be used for ranking PE-firms are total value of portfolio companies, number of funds, number of portfolio companies, and capital available for new investments. The range of capital under management ranges from USD 52.3 billion (Texas pacific Group) to USD 6.8 billion (MatlinPatterson Global Advisors). It is not surprising that 36 out of the 50 biggest PE-firms are U.S.-based and another nine of them are UK based. There is a rest of five PE-firms among the top 50 worldwide that is not of Anglo-Saxon origin. The lists below shown in Figure No 6 and Figure No 7 do not take into account the investment performance of PE-firms. 


\begin{tabular}{|c|c|c|c|}
\hline $\begin{array}{l}2009 \\
\text { PEI } 300 \\
\text { Rank }\end{array}$ & Firm name & Headquarters & $\begin{array}{l}\text { Five-Year } \\
\text { Fundraising } \\
\text { Total }(\$ \mathrm{~m})^{\star}\end{array}$ \\
\hline 1 & TPG & $\begin{array}{l}\text { Fort Worth } \\
\text { (Texas) }\end{array}$ & $\$ 52,352$ \\
\hline 2 & $\begin{array}{l}\text { Goldman Sachs Principal } \\
\text { Investment Area }\end{array}$ & New York & $\$ 48,993$ \\
\hline 3 & The Carlyle Group & Washington DC & $\$ 47,732$ \\
\hline 4 & Kohlberg Kravis Roberts & New York & $\$ 40,460$ \\
\hline 5 & Apollo Global Management & New York & $\$ 35,183$ \\
\hline 6 & Bain Capital & Boston & $\$ 34,949$ \\
\hline 7 & CVC Capital Partners & London & $\$ 33,726$ \\
\hline 8 & The Blackstone Group & New York & $\$ 30,800$ \\
\hline 9 & Warburg Pincus & New York & $\$ 23,000$ \\
\hline 10 & Apax Partners & London & $\$ 21,336$ \\
\hline 11 & First Reserve Corporation & $\begin{array}{l}\text { Greenwich } \\
\text { (Connecticut) }\end{array}$ & $\$ 20,893$ \\
\hline 12 & $3 \mathrm{i}$ & London & $\$ 18,480$ \\
\hline 13 & American Capital & $\begin{array}{l}\text { Bethesda } \\
\text { (Maryland) }\end{array}$ & $\$ 17,998$ \\
\hline 14 & Hellman \& Friedman & San Francisco & $\$ 17,900$ \\
\hline 15 & Providence Equity Partners & $\begin{array}{l}\text { Providence } \\
\text { (Rhode Island) }\end{array}$ & $\$ 16,360$ \\
\hline 16 & Advent International & Boston & $\$ 16,133$ \\
\hline 17 & Terra Firma Capital Partners & London & $\$ 14,207$ \\
\hline 18 & General Atlantic & $\begin{array}{l}\text { Greenwich } \\
\text { (Connecticut) }\end{array}$ & $\$ 14,100$ \\
\hline 19 & Fortress Investment Group & New York & $\$ 14,075$ \\
\hline 20 & Silver Lake & Menlo Park & $\$ 14,000$ \\
\hline 21 & Cerberus Capital Management & New York & $\$ 13,900$ \\
\hline 22 & Permira & London & $\$ 12,672$ \\
\hline 23 & Clayton Dubilier \& Rice & New York & $\$ 11,715$ \\
\hline 24 & Lehman Brothers Private Equity & New York & $\$ 11,710$ \\
\hline 25 & PAl Partners & Paris & $\$ 11,504$ \\
\hline
\end{tabular}

Figure No 6: 1-25 of 50 Biggest PE-Firms according to Capital Raised (compiled by PEI Media) 


\begin{tabular}{r|l|l|r}
\hline 26 & Bridgepoint & London & $\$ 10,869$ \\
\hline 27 & EQT Partners & Stockholm & $\$ 10,813$ \\
\hline 28 & Madison Dearborn Partners & Chicago & $\$ 10,600$ \\
\hline 29 & Charterhouse Capital Partners & London & $\$ 10,560$ \\
\hline 30 & Teachers' Private Capital & Toronto & $\$ 10,240$ \\
\hline 31 & Thomas H. Lee Partners & Boston & $\$ 10,206$ \\
\hline 32 & Cinven & London & $\$ 10,165$ \\
\hline 33 & Onex & Toronto & \\
\hline 34 & Riverstone Holdings & New York & $\$ 9,551$ \\
\hline 35 & AXA Private Equity & Paris & $\$ 9,400$ \\
\hline 36 & JC Flowers \& Co. & New York & $\$ 9,368$ \\
\hline 37 & Oaktree Capital Management & Los Angeles & $\$ 8,900$ \\
\hline & & & $\$ 8,846$ \\
\hline 38 & BC Partners & London & \\
\hline 39 & Candover & London & $\$ 8,748$ \\
\hline 40 & Welsh Carson Anderson \& Stowe & New York & $\$ 8,448$ \\
\hline 41 & Nordic Capital & Stockholm & $\$ 8,424$ \\
\hline 42 & WL Ross \& Co. & New York & $\$ 8,184$ \\
\hline 43 & Lindsay Goldberg & New York & $\$ 7,774$ \\
\hline 44 & & Boca Raton & \\
\hline 4 & Sun Capital Partners & (Florida) & $\$ 7,686$ \\
\hline 45 & NGP Energy Capital Management & Dallas & $\$ 7,471$ \\
\hline 46 & Alplnvest Partners & Amsterdam & $\$ 7,260$ \\
\hline 47 & Kelso \& Co. & New York & $\$ 7,200$ \\
\hline 48 & Citi Alternative Investments & New York & $\$ 7,082$ \\
\hline 49 & Marfin & Athens & $\$ 6,864$ \\
\hline & & New York & $\$ 6,830$ \\
\hline 50 & MatlinPatterson Global Advisers & & \\
\hline & & & \\
\hline
\end{tabular}

Figure No 7: 26 to 50 of 50 Biggest PE-Firms according to Capital Raised (compiled by PEI Media) 


\subsubsection{Investment Cycle of Private Equity}

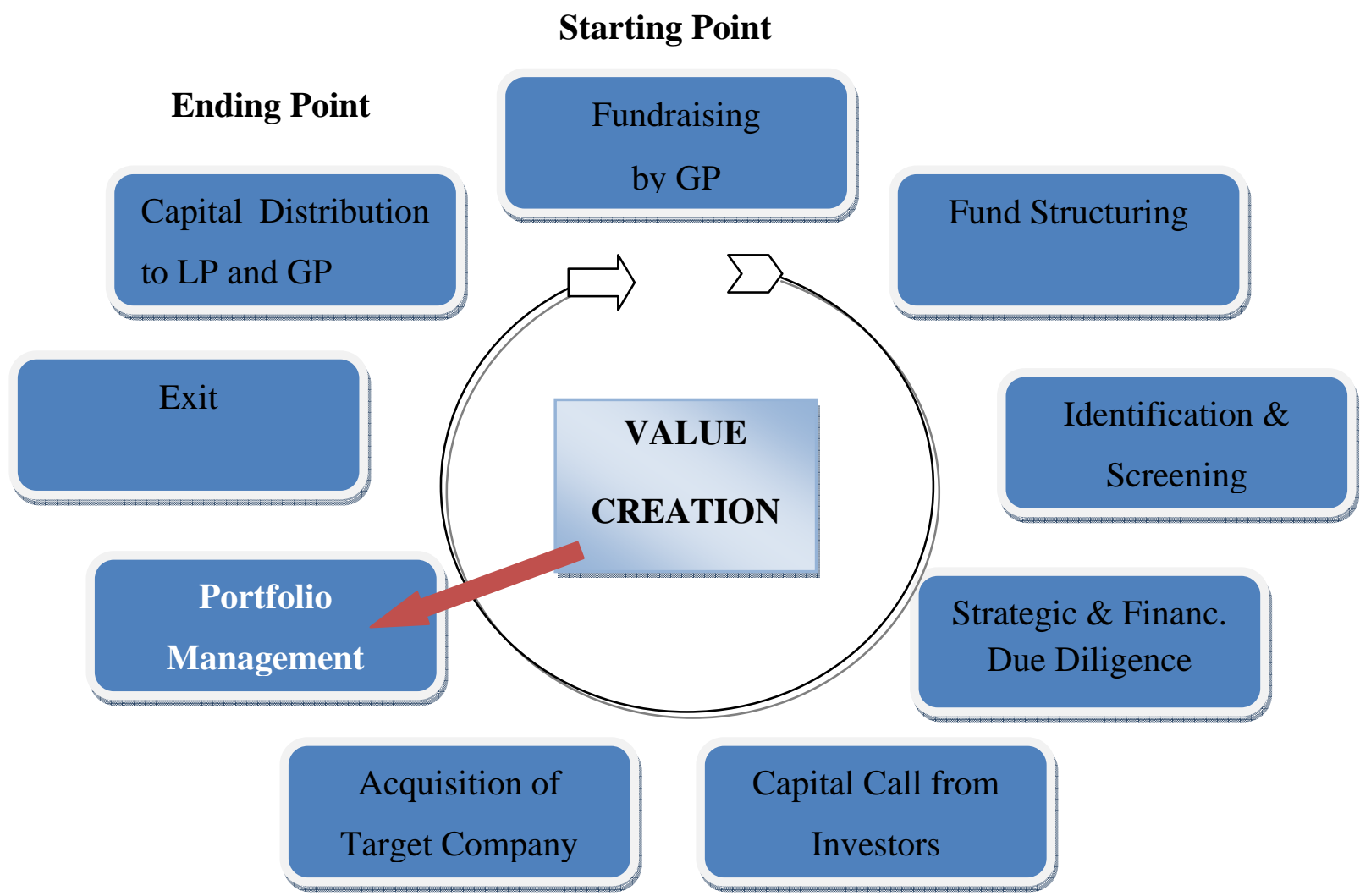

Figure No 8: Private Equity Investment Cycle

(graph compiled by author)

As table No 8 shows, the PE-investment cycle - ranging from six to twelve years - starts with fundraising activities by the PE-firm, followed by fund structuring and identification of potential portfolio companies. Once target companies are identified and investigation proves that a majority control of the company can be acquired, a financial and strategic due diligence is conducted. In case that the screened company does not turn out to be completely misjudged by the PE-professionals, LPs that have signed a LP-contract are contacted, which is called "Capital Call”. Having the necessary equity (provided by LPs) and debt (provided by banks), the financial transaction is structured and executed to acquire ownership in the target company. The red arrow in Figure No 8 shows that this thesis - in contrast to other papers that concentrate on the transaction, exit and other processes - is mainly focused on the process of portfolio management. Therefore, the second part of the literature study is mainly about value creation in the context of active portfolio management. Since the fund raising process (as the starting point) and the exit process (as the ending point of the PE-investment cycle) are quite important, the next two 
chapters deepen into these processes. The chapter about fundraising especially looks at the investors, investment trends and numbers of the last two decades.

\subsubsection{Fundraising Process}

As Kravis (2004) - one of the most famous private equity founders - put it: "The availability of financing was our biggest challenge”. In the early days of the industry raising capital was the most difficult task whereas within the last twenty years until the last financial crisis came, there was easy access to capital.

Since the financial returns of successful PE-houses have proven to be higher than other asset classes in the last two decades, an increasing number of capital-intense institutions such as pension funds, wealthy private investors and other capital sources were willing to provide high amounts of equity to leading PE-firms in order to maximize their returns. Besides the capital coming from LPs, PE-firms also use high levels of debt - provided by financial institutions - to finance buyouts. (Klier, 2009) Fundraising is a process that is simple to describe but very hard to do. A very good network alone is not sufficient. PEmanagers professionally arrange meetings with analysts and investors, which are called "Road Shows", in which they present their investment strategies. The proven performance of previous funds is of utmost importance to convince investors to commit their capital. Limited Partners sign a contract for a well defined investment volume that they are willing to provide whenever the “capital call” comes. After collecting enough capital, PE-firms have an agreed time period for investing the committed capital into companies. This period is usually three to five years. The GP also has an agreed time period when to return capital to the LPs, which is usually between eight and twelve years after the signing of the contract. (Kaplan, 2004)

From 1980 to 1995, the total amount of PE-capital under management increased from USD 5 billion to USD 175 billion representing an annual growth over 25 percent. By 1996, the two largest contributors to the PE-market were public pension funds and corporate pension funds (Mehta, 2004). Another study - conducted by Citigroup - with 50 pension managers from the United States and Europe says that there are plans to increase investments in asset classes such as private equity and hedge funds from 14 percent to 20 percent by 2010 (Citigroup Global Markets Equity Research, 2006). Anderson (2007) states in her study that the USD 112.5 billion Teacher Retirement System of Texas will increase its allocation 
to private equity from 8.5 percent to 29 percent until 2010 McKinley (2007) reports that the California Public Employees Retirement System (CalPERS), the largest U.S. publicpension fund, with assets over USD 250 billion, announced to increase their proportion of its total portfolio investing in private-equity from 6 percent to 10 percent. A study conducted by Liechtenstein, IESE and BCG (2008) reports that government-owned sovereign wealth funds (SWF) have shown their interest in Private Equity. Not only do they invest in PE-funds but they are also taking ownership stakes in PE-firms themselves. In 2007 the USD 200 billion SWF of the government of China announced that it wants to acquire a 10 percent stake in Blackstone Group - one of the biggest PE-firms - for USD 3 billion. The Abu Dhabi's SWF acquired a 7.5 percent stake in the PE-firm Carlyle Group in 2007.

\subsubsection{Exit Process}

The non-permanent nature of investments into companies is part of the business model of Private Equity. Due to this fact and the finite life of closed-end PE-funds, a natural limitation on the holding period of each investment is automatically given. As it is common understanding, PE-firms invest in companies with the clear intention of selling them after a certain period in order to make a return with profit. This buy-fix-sell mentality is directly correlated with performance since the exit provides a hard point of proof. The buy-fix-sell mentality says that the best time for owners to sell is when they have made their maximum contribution to the competitive position of their company. Common exit strategies can include a private sale to a third party or an initial public offering (IPO) which generally provides the highest amount of returns for PE-funds (Gompers and Lerner, 1999). Additionally, there is the option of a secondary buyout meaning that a portfolio company is sold from one PE-firm to another PE-firm. One of the two companies in the case study of this thesis provides a classic example of a secondary buyout. In practice, the exit process can be organised in different ways. The search for an ideal buyer of the portfolio company does not start during or at the end of the holding period. PE-firms usually analyze the market for potential buyers before they acquire a company. Nevertheless, when the end of the PE-fund's life comes closer, PE-professionals start contacting potential buyers either directly or indirectly with help of M\&A consulting companies. 


\subsubsection{Principal-Agent Relationship in Private Equity}

The general principal-agent relationship - based on literature by Pratt and Zeckhauser (1985) and Mehta (2004) - exists in economics and everyday life. When an individual (principal) depends on the actions of another individual (agent) an agency relationship comes into play. In companies, managers are the agents and the shareholders are their principals. Within this agency framework, the agent must choose an action from a number of alternative options knowing that this action affects the welfare of both the principal and the agent. It is not directly observable by the principal what the agent does and how much effort he puts into his actions, but the agent's action becomes obvious by the results produced. The principal also needs to consider that the outcome of the agent's actions is only partly influenced by the agent's chosen effort and action since it is also influenced by some exogenous factors. The main problem in agency relationships arises when the principal cannot control the agent's information and effort level without costs. The agent has better information about his task and the principal has a better idea of what he wants. Since there is an information asymmetry, the interests of both, the principal and agent, may not be aligned. That is why firms perform less efficiently than under the circumstances that information sharing between principal and agent is perfect and for free. This reduction in efficiency is known as agency loss. In the PE-industry, some mechanisms were developed to overcome information asymmetry problems aiming to minimize the agency loss. Besides the problem of hidden or asymmetric information, there is another problem named hidden action or moral hazard (Pratt and Zeckhauser, 1985). The main driver to overcome the principal-agent problem in Private Equity is the incentive system by taking ownership. As mentioned before, the interests of all parties involved have to be aligned by an appropriate incentive model that allows the relevant players - investors, PE-professionals, Operating Partners and especially executives of portfolio companies - to participate in the realised value creation. That is not only possible by a performance based bonus system but it also needs everybody's private capital to be at stake. Also according to Jensen's (1986, 1989) free cash flow theory, PE-buyouts result in corporate governance changes reducing agency costs. 


\subsubsection{Economic Crisis and Impact on Private Equity Industry}

Generally, it can be said that economic crises are all different from each other, and each crisis is so complex that books could be filled. First, one has to differentiate between the last financial crisis, which started mid 2007 with a peak in September 2008, and a recovery in 2009, and the following crisis of the real economy, which started later and has not yet fully recovered. In this work, the general term “economic crisis” is used for both types of crises. This chapter is limited to some examples and highlights of the current economic crisis in connection with Private Equity. Different numbers - also shown in other chapters such as fundraising - reveal that the PE-industry has been hit hard and sustainably by the current crisis. One of the major cutbacks of the crisis was the difficulty to raise new funds. Also the biggest global PE-firms were hit. One of the biggest PE-house worldwide Carlyle Group - cut 10 percent of its workforce in 2008. That was the first layoff in the company within 22 years of business. Also Blackstone Group, 3i, and other large PE-firms have followed the trend (Pappas, Allen, Schalock, 2009). In particular, some cancellations of large PE-deals raised doubts about the ability of Private Equity to sustain its business model and high returns to LPs. The credit crunch of the last two years has made debt more expensive, which makes deals less attractive and requires a higher percentage of equity from LPs for every deal. The cost of debt began to rise in the mid of 2007, but very soon credit spreads have returned to levels of 2005. The economic recession has also caused many portfolio companies of PE-firms to underperform. This new situation had to be accepted in terms of prolonging holding periods and changes of exit plans. Besides some financial institutions troubling with equity problems, there are still strong banks that are not that strongly affected by the current debt write-downs. Therefore, they are still willing to provide debt for financially stable midsize deals with stable cash flows and clear opportunities for growth and value creation. [Liechtenstein (2008); Matthews, Bye and Howland (2009)]

The PE-industry is on one side waiting for higher valuations in order to make profitable exits, and on the side expecting lower valuations in order to buy cheap during the crisis. Since there were not many acquisitions by PE-firms in 2009, most of the PE-houses still have enough capital that needs to be invested. Therefore, they wait for the right opportunities to acquire companies. So, despite recent troubles of financing and valuation the basic elements of the PE-business model remain in place. In terms of scientific research 
it could be observed that the immense rise of PE-funding from 2003 until 2007, and even more so the influence of the last crisis including its consequences has brought research on private equity to new horizons.

\subsection{Value Creation}

For a better understanding of the general term "value" - especially in the economic context of companies and in terms of ownership - this chapter starts with a glance to public corporations. Not many division managers or executives have a real sense of ownership, neither do they know the intrinsic value of their units or corporations. Nevertheless, sustainable value creation in a company is of great interest to shareholders and should also be of interest to its managers. Literature suggests that personal biases and hopes influence the perception of value. Due to the fact that managers, shareholders and analysts think differently, they all have different views on valuation and how corporations actually work. One often hears that corporate valuation is rather art than science since future assumptions are taken into account. Yet, value and value creation is not an opinion, and not difficult to quantify. First, financial values can be calculated according to the different ways in which cash flows are projected. Secondly, intangibles - such as manpower, brands and licences have to be taken into account for a corporate valuation. Nevertheless, the ultimate value is cash that is ultimately generated and returned to the investors.

As it is also mentioned by Hass and Pryor (2009) some accounting standards such as GAAP are not very suitable for describing the real economics of a business. GAAP provides distorted starting figures for estimating the intrinsic value of a firm. PE-owned portfolio companies are required to provide cash budgets and forecasts to their owners, while many public companies hesitate to give forecasts. Only very good business managers and PE-investors research and calculate the drivers of future cash flows and value. Consequently, they are able to allocate capital and adjust actions based on DiscountedCash-Flow (DCF) calculations. An implemented scorecard system based on value creation is a helpful tool for valuation. Before investing into a company PE-investors closely investigate if the target company is using a value-based scorecard system to track value and performance. If not already implemented, PE-houses require their portfolio companies to establish an accurate balanced scorecard system and a strong financial controlling system. Therefore, as common business sense and literature suggest, value creation within 
in this thesis is understood as a mixture of EBITDA-growth, sales growth, increased return to investors and economic value added.

\subsubsection{Introduction and Literature Review}

"Operational value creation is the key element in private equity that will distinguish the winners from those that disappear" (partner of a large pension fund investing in Private Equity)

This chapter deepens into the characteristics of value creation showing interesting results of existing studies. In the past, creating value in Private Equity was primarily about selecting good companies with stable cash flows and using financial leverage effects. The circumstances for cheap debt financing have changed tremendously and have reduced the ability of PE-firms to create value through financial engineering. Nowadays, the trend has gone towards creating sustainable company value (Liechtenstein, 2008).

The growing concentration on fundamental value creation in the PE-industry shows the importance of this key to success. Nevertheless, the shift from financial levers to operational value creation through active ownership is not new in Private Equity. Stalk (1992) states that the most successful global acting PE-firms have changed their modus operandi already in the early nineties of the last century. These PE-firms have set up their organizational structure and capabilities in a way that they are able to act as active owners of their portfolio companies. Additionally, they are able to identify the best deals in their core industries, bid competitively and have the knowledge and structure to transform the performance of their portfolio companies. Besides harder conditions for debt financing, also pressure from the investor side has grown. Limited partners investing in Private Equity have defined stricter criteria and perform a due diligence of the PE-house they want to cooperate with. The importance of operational value creation expressed by EBITDA growth is stressed from the investor side.

The IESE/BCG (2010) research on value creation by operational improvement addressed the question of how PE-firms ameliorate the market position of their portfolio companies. Therefore, they investigated 3,000 capital investments into Private Equity and conducted 20 in-depth interviews with limited partners. The results show that some of the largest funds have generated more than 75 percent of their internal rate of return (IRR) through 
operational value, while smaller funds have created more than two-thirds of value creation using financial levers. From the mentality side, there is a big difference between the pure financial investor approach and the active ownership approach. Operational value creation can be seen as the result of a business mentality whereas financial levers have more to do with a trader mentality. Another difference is that financial leverage and multiple-arbitrage create value for the shareholder but they often harm the competitive position of the company. Sustainable value can, therefore, only be created through operational value creation and appropriate corporate governance structures.

The interview based study by Klier, Welge \& al. (2009) states that active ownership by PE-firms adds substantial value to the portfolio companies. The performance difference between active and passive investors reveals that active investors outperform less active management models by a substantial margin. Over a five-year investment horizon, active portfolio management models generate an average outperformance of five percentage points in net IRR versus passive investors. Over a 10-year time frame, the performance gap grows considerably. Active investors achieve an average net internal rate of return of 28 percent in contrast to financial investors with 15 percent. In opposite to other studies in this field, structural factors do not influence the results. Neither size of the investment portfolio nor the experience of the firm - measured in years since the vintage date of the firm's first fund - can explain the performance difference. Interestingly, some of the largest and oldest private equity firms are leading the study results. That may suggest that size and track record are of importance even if the author claims the opposite.

In a recent McKinsey research by Heel and Conor (2005) eleven leading PE-firms with above-average track records were studied. The finding was that there is a strong correlation between five steps private equity firms could take to direct a portfolio companies. Each of the studied PE-funds submitted five or six deals from which they had exited. The deals show a range of returns from average to very good. The main source of value creation in nearly two-thirds of the deals in the investigated deal sample was company outperformance. Market growth, financial leverage and arbitrage counted for the rest of one third of value creation. After conducting extensive literature review on value creation in private equity one finds out that only a handful of scientists focus on this question, whereas consulting and accounting companies conduct much more studies about on this question. 


\subsubsection{Studies on Transaction Level}

On the transaction level, empirical work on value creation has mainly covered the U.S. and U.K. market. Relevant studies were done by Kaplan (1989); Guo, Hotchkiss, and Song (2007); Groh and Gottschalg (2009). In the U.S.A. and the U.K., Nikoskelainen and Wright (2007); Acharya, Hahn, and Kehoe (2009) have investigated this topic. Since most of the scientists are working in the Anglo-Saxon cultures, most of scientific publications focus exclusively on the Anglo-Saxon markets. Additionally, they fail to analyze value creation in a study framework that clearly distinguishes between operational and financial value drivers. Acharya, Hahn, and Kehoe (2009) use a similar approach to separate financial and operational value drivers, although with a different research focus, which is explained in the next chapter. The following pages should provide an overview of the existing research studies and the scientific approach taken.

\begin{tabular}{|c|c|c|c|c|c|}
\hline Author & $\begin{array}{l}\text { Publication } \\
\text { Date }\end{array}$ & Region & Sample & Period & Results \\
\hline $\begin{array}{l}\text { Acharya / } \\
\text { Hahn / Kehoe }\end{array}$ & 2009 & U.K. & 66 companies & $\begin{array}{l}1996- \\
2004\end{array}$ & $\begin{array}{l}\text { Operational PE alpha of } 8.9 \\
\text { IRR \% }\end{array}$ \\
\hline Achleitner & 2010 & $\begin{array}{l}\text { mainly } \\
\text { EU }\end{array}$ & $\begin{array}{l}241 \\
\text { companies }\end{array}$ & $\begin{array}{l}1989- \\
2006\end{array}$ & $\begin{array}{l}\text { 2/3 of value increase } \\
\text { generated by operational } \\
\text { and market effects }\end{array}$ \\
\hline BCG / IESE & 2008 & Europe & 32 companies & $\begin{array}{l}2000- \\
2006\end{array}$ & 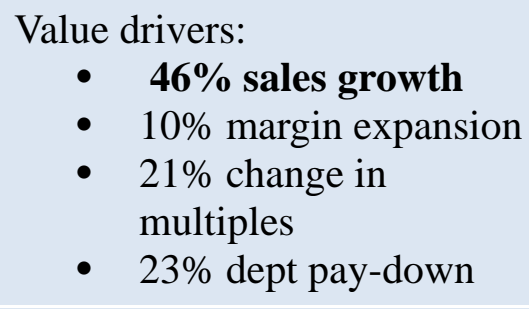 \\
\hline $\begin{array}{l}\text { Groh/ } \\
\text { Gottschlag }\end{array}$ & 2008 & U.S & $\begin{array}{l}133 \\
\text { companies }\end{array}$ & $\begin{array}{l}1984- \\
1996\end{array}$ & $\begin{array}{l}\text { Operations PE alpha of } \\
12.7 \% \text { IRR }\end{array}$ \\
\hline $\begin{array}{l}\text { Guo / } \\
\text { Hotchkiss / } \\
\text { Song }\end{array}$ & 2008 & U.S. & 92 companies & $\begin{array}{l}1990- \\
2007\end{array}$ & $\begin{array}{l}\text { Operational improvements in } \\
\text { PE backed companies } \\
\text { comparable to those of public } \\
\text { listed peer companies }\end{array}$ \\
\hline Loos & 2005 & $\begin{array}{l}\text { U.S / } \\
\text { Europe }\end{array}$ & 57 companies & $\begin{array}{l}1980- \\
2001\end{array}$ & 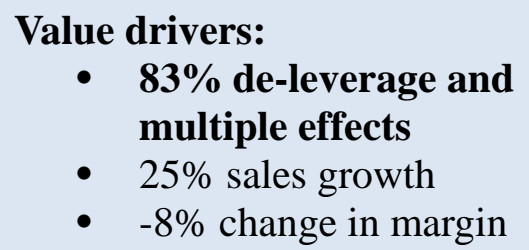 \\
\hline
\end{tabular}

Figure No 9: Overview of Studies on Transaction Level - compiled by author 
Acharya, Hahn and Kehoe (2009) examine deal-level data on private equity transactions (by mature private equity houses) in the UK in the time period from 1996 to 2004. The study sample consists of 66 deals of twelve large and mature PE-houses in the UK. The methodology used is based on returns and leverage information at the deal level and the returns and leverage of a peer group in order to extract a measure of abnormal performance of the deal ("alpha”) at enterprise-level. They un-levered the equity return on each deallevel and adjusted for return to quoted peers in the industry to extract a measure of "alpha". The result shows that the deal-level alpha outperformance is stronger during sector downturns and correlates high with operating outperformance of deals relative to quoted peers measured as improvement in margins and multiples relative to the quoted sector. So, higher alpha is related to greater improvement in EBITDA to sales ratio and greater growth in EBITDA multiple during the private phase, relative to that of quoted peers in the industry. Additionally, deals with higher alpha either grow their margins significantly, and/or grow multiples more substantially in combination with revenue expansion. The finding of qualitative research based on interviews with general partners involved in the deals reveals that deals with higher alpha and higher margin growth are associated with greater intensity of engagement of private equity houses especially during the early phase of the deal. Value-creation initiatives for productivity and organic growth as well as support for top management with external experts came additionally. The results of Acharya, Hahn and Kehoe (2009) can be interpreted as a microscopic view on expertise in operational improvement applied by mature PE-firms in turning around companies they acquire. These results are consistent with the thesis that mature private equity houses create value for portfolio companies through active ownership and governance. Seen from an economic standpoint, value creation by Private Equity concerns the sustainable vitality of portfolio companies even after the exit scenario. In addition to that, significant political interest has been expressed in understanding the long-run impact of private equity in terms of value creation at the enterprise level. The source of value creation either stemming from financial engineering, systematic risk or operational engineering is of special interest to the public and politic.

In the scientific paper "Value Creation Drivers in Private Equity Buyouts: Empirical Evidence from Europe”, Achleitner, Braun, Engel and Tappeiner (2010) focus on two shortcomings of former studies because they include a framework separating financial drivers from operational improvement and they analyse European buyout transactions. 
Their sample stems from a database from a leading European fund-of-funds that was compiled for the due diligence of PE-houses. The sample was narrowed down by only including the European region and those transactions in which the value creation could be traced and separated between leverage contribution and other factors. The sample contained 206 buyout transactions from 1991-2005 including transactions from 27 different PE-firms and 20 different countries. 44 percent of all transactions were in the UK, 17 percent in France, 10 percent in Sweden, 6 percent in Germany and 3 percent in the Netherlands. The average holding period was 3.6 years, which is comparable to recent studies of Nikoskelainen and Wright (2007) but lower than the average of 4.2 years for the period 1970 to 2007 in the study of Strömberg (2008). Value creation models in Private Equity used by practitioners differentiate between three basic value creation drivers:

- EBITDA growth

- EBITDA multiple expansion

- debt repayments

EBITDA growth can be further split into the contribution of sales growth and EBITDA margin improvements. However, this described value creation approach does not explicitly take into account that the return expectations of the owners consist of two components operational risk and financial risk. In order to quantify the return that can solely be attributed to a transaction's financial risk, the levered returns to equity holders need to be unlevered. This allows a financial-risk-adjusted comparison across different deals. The unlevered return - excluding the leverage effect - is divided into three conventional value drivers:

- EBITDA growth

- free cash flow (FCF) effect

- multiple effect

The value contribution of EBITDA growth is the difference in EBITDA between entry and exit multiplied with the EBITDA multiple at entry. The FCF effect represents the free cash flow on a company level that can be used for paying down debt and possibly for financing dividends. The contribution of the multiple effect is the multiple change between entry and exit multiplied with the EBITDA at entry. The results reveal that operational improvements are more important than the financial leverage. One average, the main 
operational drivers EBITDA growth and FCF-effect account for 46 percent of total value creation, while the leverage effect accounts 32 percent of total value creation. 18 percent of value creation can be attributed to multiple expansion and the combination effect of EBITDA growth and multiple expansion accounts for 4 percent of total value creation. That means that a third of total return is made due to financial engineering. Since higher debt-to-equity ratios include increased financial risk in transactions, the additional leverage-return could be interpreted as a risk premium. Interestingly, banks often accept higher debt-to-equity ratios of PE-backed companies compared to companies not backed by PE-firms due to the reputation and experience of PE-sponsor. That goes along with the fact that portfolio companies need to generate considerable EBITDA growth and FCF in order to fit into the PE-business model. The findings of Achleitner, Braun, Engel, and Tappeiner: (2010) can be summarized that two-third of value creation come from operational improvements. This result suggests that for deals completed in 2009-2011 the importance of operational improvements will increase, which supports the thesis that active portfolio management is a distinguishing feature in Private Equity.

In a joint-study of BCG and IESE (2008) Liechtenstein, Prats and Herrera together with Meerkatt, Rose and Brigl have investigated "How the Best Private-Equity Firms Beat the Fade”. Therefore, they analyzed the value creation of 32 companies in the portfolios of seven European private-equity firms. They compared the enterprise value of the businesses at the time when they were purchased with the value realized upon exit, and quantified the relative impact of key value drivers. Their finding is that half of the value created (22 percent out of a total average internal rate of return of 48 percent) comes from sales growth, and additional 5 percent are originated by improvements in margins. The valuation multiples attributed 10 percent to the total return. This can be partly explained by improved performance prospects at the time of exit, and partly by the systematic increases in multiples across the capital markets. Surprisingly, the average leverage effect was only 11 percent of total return, which is half as much as sales growth and less than a quarter of the total return. 


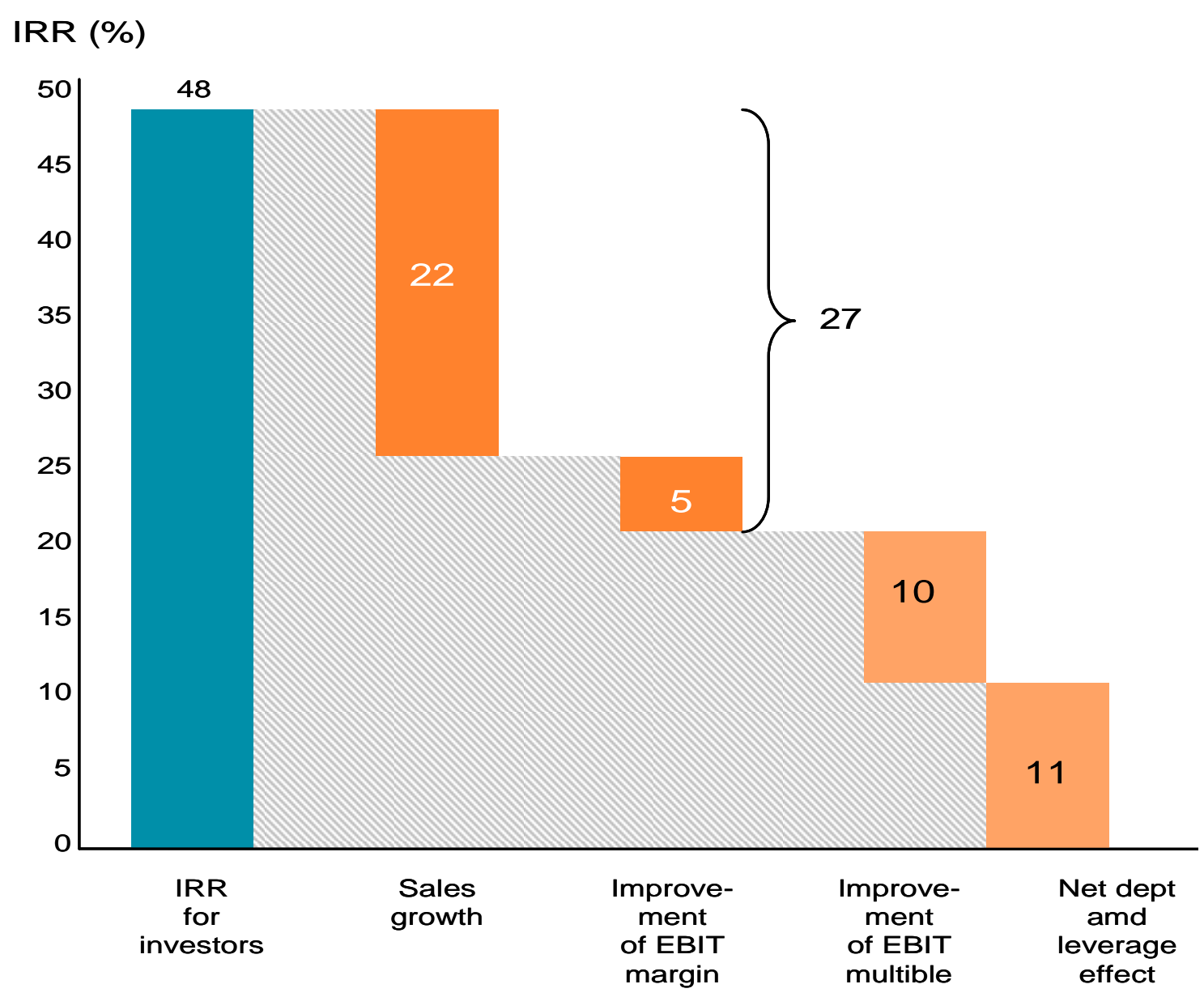

Figure No 10 Fundamental Value as Main Source of Value Creation - compiled by BCG

Guo, Hotchkiss and Song (2007) examined in their paper "Do Buyouts (Still) Create Value?” how and to what extent leveraged buyouts of public to private transactions created value. In terms of data they used Dealogic database to identify leveraged public to private buyouts of U.S. firms with deals values of at least USD 100 million and announcement dates between January 1990 and July 2006. This produces a sample of 192 LBOs from 1990 to 2006. In contrast to deals in the 1980s more firms come from service industries (28 percent) and fewer from manufacturing (36 percent). The sample includes a total of 120 different PE-firms involved in the buyouts. The deals of the study involve more than one private equity sponsor and are frequently connected with significant asset restructuring. They show that the firms in the sample experience - on average - large increases in total value from the time of the buyout to the exit, therefore they produce large returns to invested debt and equity capital. In order to estimate returns to total capital they used the methodology of Andrade and Kaplan (1998), who calculated returns from the buyout to the 
exit case. Their results also show that returns to buyout capital are positive and significant for all groups except deals ending in a distressed restructuring. Median market and riskadjusted returns to buyout capital are estimated at 72.5 percent even including the cases of distress. There are the following three different explanations for the documented realized returns:

- Firm value increases if there are firm-specific improvements in operating performance. Profitability is increased in the portfolio companies of their sample, unproductive assets are eliminated and working capital is used more efficiently.

- Even in case that there are no changes in the cash flows after becoming a PEportfolio company, firm values may benefit from rising market or industry sector valuation multiples.

- Substantial increases in financial leverage produce efficient tax shields that boost returns by increasing the cash flows available to the providers of capital.

Surprisingly, they find that gains in operating performance are substantially smaller than documented for deals in the 1980s. In contrast to other studies the median performance reported is not always significantly different from the performance of benchmark firms. Another finding in their study is that gains in operating cash flows are greater for firms where the private equity firm has replaced the CEO soon after the time of the buyout. To examine three potential determinants of realized returns, they quantify the impact of changes in operating cash flows, changes in valuation multiples, and tax benefits from increasing debt. For the full sample they show that improvements in performance make 23 percent of the buyout return. Also the changes in industry valuations also have a large effect on returns, which is shown by the following ratios:

- 18 percent in change of total capital/EBITDA ratio

- 26 percent of the return for firms generated exiting through an IPO

In general it can be stated that the results of Guo, Hotchkiss and Song (2007) show that the deals are more conservatively priced and less financially levered than those in the 1980s.

The following study - done by Nicolaus Loos (2005) in the framework of his dissertation - addresses the sources of value creation in leveraged buyouts. Prior studies in the field of Private Equity research suffered from a lack of accessibility to the highly confidential buyout deal and fund performance data of Private Equity firms. Loos based his research on 
collaborations with leading Private Equity Fund investors gaining access to their vast archives of collected information. That includes performance data of a sample of more than 3,000 realized and unrealized leveraged buyout transactions, undertaken by 84 of the major buyout-focused U.S. and European Private Equity firms, drawn from 252 of these firms' funds between 1973 and 2003, with the majority of transactions taking place during the 1990s. The theoretical part reviews two competing explanations for the phenomenon of apparently significantly higher value generation of leveraged buyouts undertaken by financial buyers in comparison with peer companies on the one side, as well as in comparison with common merger and acquisition activity of strategic buyers on the other side. The agency theoretical explanation goes into essential changes in corporate governance structures at buyout targets after the acquisition. The interaction and knowledge transfer between the PE-firm and its portfolio companies can be seen as most important reason for value generation. The empirical part is structured into three parts. The first empirical chapter starts with an overview of kinds of buyout transactions based on PEinformation provider Thomson Financial Venture Economics including PE-fundraising and fund performance history. Based on the primary transaction dataset collected from Limited Partners, the study shows evidence that several of the examined exogenous factors - listed below - have demonstrated to be statistically significant value drivers in the leveraged buyout value creation process, which is measured by the internal rate of return (IRR) of the gross deal performance.

- entry and exit years

- $\quad$ entry and exit types

- entry and exit modes

- industry

- country/origin

- amount of invested capital

- $\quad$ percentage of ownership

- $\quad$ holding period

- acquiring PE-firm

- industry and equity market performance 
The second empirical chapter examines endogenous factors of value creation. The Private Equity firms examined in this study were screened according to their investment managers' level and type of education, professional experience as well as the PE-firm's hierarchical structure and deal-making experience profile. The results reveal that the professional experience, and to a certain also the degree of the investment managers' education, has a significant impact on gross returns. In addition, the PE-firm's organizational structure, team composition and diversity are statistically significant to play an important role in terms of returns. This study proves evidence for the existence of a learning effect in buyout transactions. Strong transaction experience and a geographic investment focus are positively correlated to performance, whereas a focus limited fewer industries does not. These findings show the so called "GP effect" in leveraged buyouts. The third chapter of the empirical study analyzes statistical results of strategic value drivers. That includes observable strategies that buyout firms follow. The micro-level analysis of the portfolio companies shows surprising results regarding buyout target characteristics. It demonstrates that an exchange of top management teams as well as organic deals by further M\&A growth (rather than cost cutting and divesting strategies) have a positive impact on transaction returns.

\subsubsection{Studies on Fund Level}

On the fund level, scientific contributions that compare fund performance to a public market equivalent are those of Kaplan and Schoar (2005), Phalippou and Zollo (2005), and Kaserer and Diller (2005).

\begin{tabular}{|l|l|l|l|l|l|}
\hline $\begin{array}{l}\text { Kaplan } \\
\text { / Schoar }\end{array}$ & 2005 & n/a & $\begin{array}{l}\text { 746 funds } \\
\text { (thereof 169 } \\
\text { buyout funds) }\end{array}$ & $\begin{array}{l}1980- \\
2001\end{array}$ & $\begin{array}{l}\text { Net returns (net of fees) of } \\
\text { PE funds equivalent to those } \\
\text { of “Public Market } \\
\text { Equivalents” }\end{array}$ \\
\hline $\begin{array}{l}\text { Kaserer/ } \\
\text { Diller }\end{array}$ & 2005 & Europe & 200 funds & $\begin{array}{l}1980- \\
2003\end{array}$ & $\begin{array}{l}\text { Net returns of PE funds } \\
\text { equal those of Public Market } \\
\text { Equivalents }\end{array}$ \\
\hline
\end{tabular}

Figure No 11: Overview of Studies on Transaction Level - compiled by author

Kaplan and Schoar (2005) investigate in their paper "Private Equity Performance: Returns, Persistence and Capital Flows” the performance of private equity partnerships in comparison with Public Market Equivalents. The data set for their study comes from 
Venture Economics, which is based on voluntary reporting of fund information by the private equity firms as well as by their LPs. The data of the sample cover the years 1980 to 2001. The quarterly performance measures that were collected from GPs and LPs are the internal rate of return (IRR), the cumulative total value to paid-in capital (TVPI), the distributed total value to paid-in capital (DPI) and the quarterly cash flows in and out of each fund for the life of the fund. The authors studied three issues that have not been examined previous to 2003. They look at the characteristics of fund performance in the PEindustry in general. The market is characterized by a large heterogeneity in returns across funds and time periods. This study reveals that - on average - the LBO-fund returns are lower than those of the S\&P 500. Over the entire sample period (1980 to 1997), average fund returns net of fees are more or less equal to those of the S\&P 500. In terms of gross of fees PE-partnerships earn returns exceeding the S\&P 500. They find that performance persists for all measures of fund performance. They also document that performance increases with fund size and with the PE-firm's experience. A positive track record affects the partnership's ability to attract capital into new funds. There is some evidence that funds that are raised in boom times and firms that are started in boom times are less likely to raise a follow-on fund meaning that these funds perform worse. These empirical relations between performance and capital flows differ substantially from the ones found for mutual funds. That could be explained by the skill-model of GPs. If there is a connection between fund performance and GP skills, the question remains why returns to superior skills are not remunerated in the form of higher fees. That brings us back to the statement that the skills of PE-people - in order to improve performance of portfolio companies - are of major importance in this industry.

The paper "What Drives Cash Flow Based European Private Equity Returns?” written by Kaserer and Diller (2004) analyzes the determinants of returns generated by European private equity funds. This paper extended the then existing literature for four reasons, which are further explained. The final data set includes 200 mature European private equity funds from 1980 to 2003 provided by Thomson Venture Economics using various information related to the timing and size of cash flows, residual net asset values (NAV), fund size, vintage year, fund type, fund stage and liquidation status. For their methodology they have developed a regression model explaining more than 47 percent of variation in private equity returns. The methodology also includes a test for the "money chasing deals" 
phenomenon. That means that they make a distinction between absolute and relative cash inflows into private equity funds in this study. They also present evidence that investor sentiment matters since funds closed in years with above average stock market conditions generate lower returns. Their regression approach shows that returns are positively associated with GP's skills as well as with idiosyncratic risk. The authors argue that Private Equity as an asset class is characterized by illiquidity, stickiness and segmentation. The aim of this paper is to document that this phenomenon also explains a significant part of variation PE-funds' returns. This is especially true for venture funds, as they are more affected by illiquidity and segmentation than buy-out funds. The paper, therefore, presents a regression model that explains 47 percent of variation in funds' returns. Apart from the importance of fund flows it can be seen that the GPs' skills as well as the idiosyncratic risk of a fund do have a significant impact on returns.

\subsubsection{Portfolio Management Models in Private Equity}

Since active portfolio management has become a trend respectively a must in the PEindustry, many PE-companies claim to be strong in value creation in the portfolio companies. Practice shows that this does not hold true. The PE-industry can be divided into two very different portfolio management models. One form, which is called "passive investor" in this work, represents the traditional form of private equity focusing on financial engineering and some changes in the corporate governance structure of portfolio companies. The other form - represented by "active investors" - is a modern form of private equity with active involvement in decision making and a focus on value creation through active ownership. The findings in relevant literature confirm the suggestion that investors with an active portfolio management approach generate considerably higher net returns than more passive financial investors. The difference is that passive investors focus their activities mainly on changing the capital structure and, sometimes, the corporate governance structure of their portfolio companies, whereas active investors follow an active ownership model of value creation. Active investors act with strong involvement in decision making concerning their firm's strategy and operations, and still apply the possible financial and corporate governance engineering models of the traditional PEmanagement model. That includes all activities of the traditional PE-model - the use of financial leverage, the alignment of interests, and the active role on the board of a portfolio 
company - but it additionally requires active ownership including operational improvement action steps. All PE-partners need to review their management models for opportunities how to support value creation in their portfolio companies. The portfolio management model of active investors is not a completely new form of PE-ownership but it has developed to become a distinguishing feature in Private Equity (Klier, Welge \& al., 2009). In the next two chapters the different forms of portfolio management are explained in-depth before delving into the explanation of possible value creation tools that can be applied.

\subsubsection{Passive Portfolio Management}

The main focus on value creation of passive investors in Private Equity is largely through financial engineering and improvements to a firm's governance structure by implementing strong financial incentives. This passive portfolio management approach has the attempt in difference to active investors - to create value at the time of the deal rather than during the holding period of the portfolio company. This observation can also be found in papers of Cotter and Peck (2001), Kaufman and Englander (1993) and Palepu (1990).

As mentioned several times in this thesis, PE-firms use financial leverage by borrowing substantial amounts of debt to acquire a target company that is then paying down the debt. The advantage of the leverage is the creation of a financial long option on the business they acquire since there is only limited potential downside risk due to the relatively small equity part. Zong (2005) explains that the de-leveraging of the portfolio company is supported by additional other measures on the balance sheet such as the sale of non-core assets and reductions in working capital. The pressure of high leverage (debts) and the obligations to pay down the debt and to make interest and principal payments result in the fact that portfolio companies have to behave stricter with their free cash flow than they did before the PE-ownership. Consequently firm's free funds cannot be spent on inefficient projects (Cotter and Peck, 2001). Usually, PE-investors change the incentive systems in their portfolio companies in the form that they oblige the top management to invest substantial amounts of private money in the company, which creates a strong link between performance and compensation. The interests of the PE-firm, its investors and the management, as partly-owners have to be aligned to create value together as one team [Nikoskelainen and Wright (2007); Klier, Welge \& al. (2009)]. 


\subsubsection{Active Portfolio Management}

"Investments do not govern themselves, so active ownership is the right answer to this problem" as it is stated in a McKinsey study (2005) on active portfolio management. Active portfolio management takes an approach of active ownership within the portfolio companies of PE-firm. Active investors focus on core-industries, in which they have strong experience, in order to exploit the advantages of knowledge and market power. Within the structure of a PE-company dedicated industry teams with considerable industry expertise have to be built. As mentioned in the introduction of this thesis, a team of PE-professionals has to cover backgrounds from banking, consulting, and industry positions. Only by implementing a stronger industry orientation in the professional PE-team and by focusing on related businesses PE-firms are able to exploit the benefits of industry relatedness. The described setup of skills and industry focus enables value creation during the entire holding period of an investment and not only when acquiring and later selling a company. In further chapters the issue of business intervention is discussed in detail. Anyway, all intervention should happen as informal as possible, so that businesses can remain independent. Otherwise, the power position of a firm's management is undermined. Additionally, also an increasing linkage of portfolio businesses and greater influence in strategic decision-making may limit the accountability of a portfolio's management team. The active portfolio management approach relies on the strengths of financial engineering, governance engineering, but is includes the so-called active ownership. Nevertheless, the disadvantage is that active investors need a highly professionalized and larger group of investment professionals as passive investors leading to higher costs in the PE-firm. (Klier, Welge \& al., 2009) The above mentioned study by Acharya, Hahn and Kehoe (2009) provides a chart showing the timeline of active governance in a typical PE-transaction. 


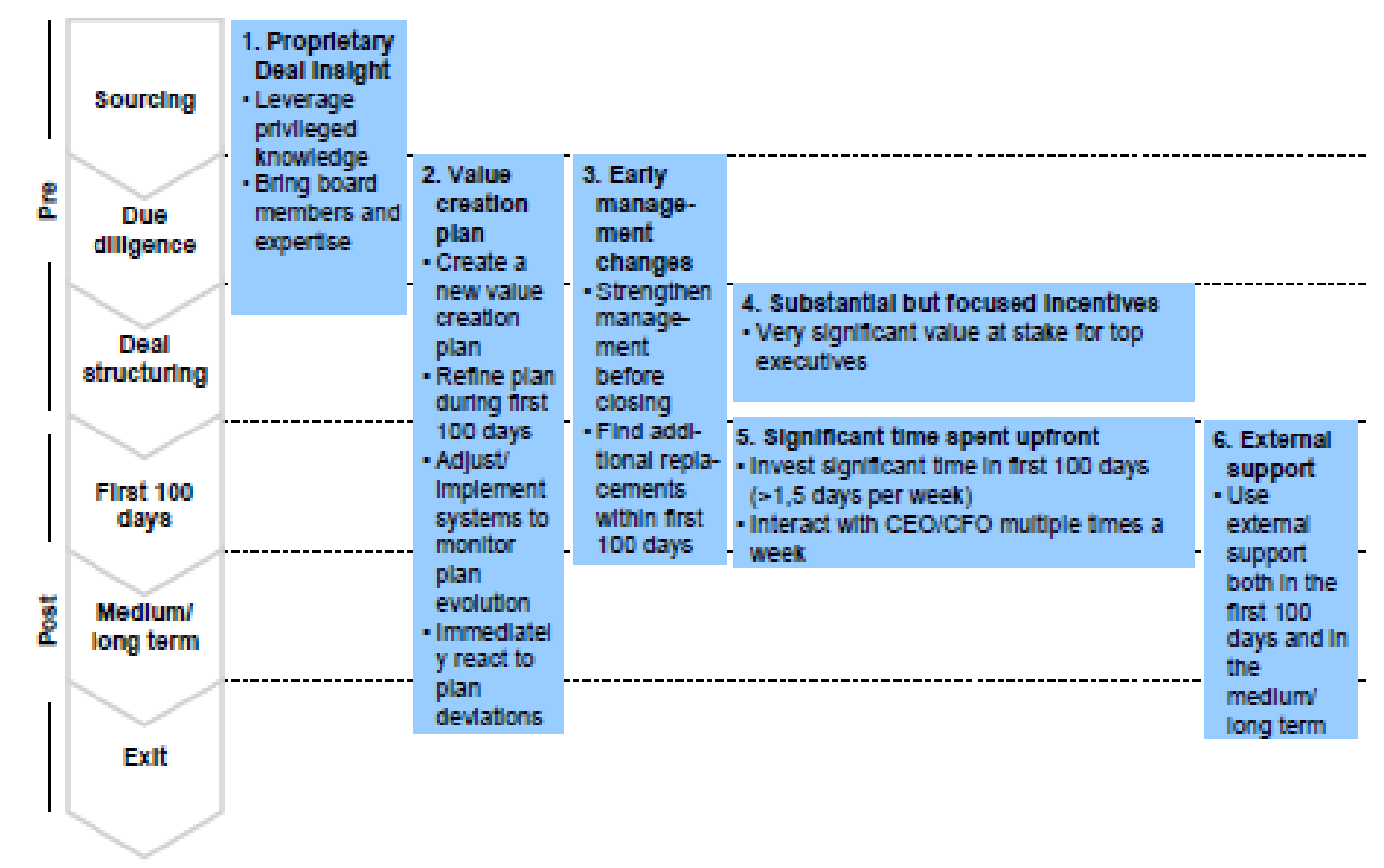

Figure No 12: Company Outperformance driven by Active Ownership Practices Deployed in the Acquisition Process and Post-Acquisition (complied by Hahn)

It is interesting to look at the four major steps of value creation developed by Hass and Pryor (2009) in their paper "What Public Companies Can Learn from Private Equity: Pursue the Value Journey. Hass and Pryor have built this hands-on operational model for public corporations in order to show what they can learn from Private Equity. With some adjustments this kind of "value-guide" can be re-transferred to active value creation in portfolio companies of PE-firms.

1. Talk and think value! Constant communication to the work force is the key.

- Set the right goals based on value!

- Communicate verbally to change the culture and involve as many employees as possible to understand how to build value!

2. For improvement of cash flow implement metrics such as return on invested capital, customer retention, customer value, and growth by sales!

- Analyze served market size, growth and market share trends. Provide incentives based on value-based metrics!

- Implement a value-based scorecard in the ERP! 
- Understand the structure of value drivers: SBU, product, and customer!

3. Report and act on value insights by disclosing where the performance improvement comes from!

- Report on value-based trends monthly at the operational level and at least quarterly to the board!

- Develop plans for potential result-and risk explanation as well as how better results will be achieved and risks mitigated!

- Execute plans to improve portfolio value, reduce risk and cut losses!

4. Communicate the goal of achieving value builder status!

- Recognize that companies do not earn 20 percent returns if they serve the wrong markets with the wrong products and even less so if they are guided by leaders who are not good communicators and value builders!

- Once superior returns are achieved, ask how long they are possible in the face of competition!

- Understand market values relative to intrinsic value, hence knowing better when to buy and when to sell!

\subsubsection{Criteria and Factors of Active Portfolio Management}

\subsubsection{Structural Factors}

There is a strong academic discussion on whether structural factors such as firm size and fund size do play a role in terms of value creation and returns, or if they are of relative unimportance. Obviously, in practice there is a clear trend towards bigger, more global, and more diversified firms. Various scientists did studies on the impact of structural factors coming up with different results. Some observers have even argued that structural factors are of major importance for success in the PE-industry. In a joint-study of BCG and IESE Liechtenstein et al. (2008) also tested this assumption besides other factors of value creation in Private Equity. They identified 20 PE-firms that were among the 35 largest in the industry. By using Preqin data they analyzed the correlation between firm performance and four structural factors: 
- Average fund size

- Average deal size

- Degree of geographic diversification

- Degree of industry diversification

Their finding is that there is little correlation between those structural factors and the performance of PE-firms. As a first example of the unimportance of structural factors they point out the average fund size ranging from USD 200 million to almost USD 2.5 billion. Some of the most successful firms in the sample have the very small average fund sizes. In contrast to the above stated suggestion, Kaplan and Schoar (2005) investigated that performance increases with fund size and with the partnership's experience. A partnership's track record of successful deals positively influences the partnership's ability to attract LPs to invest into new funds. Also Demiroglu and James (2009) proved that the size of PEcompanies is a factor that helps to get bank financing at better terms, and therefore, improve the leverage effect. So, the most reputable PE-firms have no problems to receive higher amount of leverage. IESE and BCG (2008) tested the factor of deal size in a study of deals with 20 firms ranging from USD 200 million to USD 1.1 billion in deal size. In terms of deal size, they found no clear correlation between deal size and a PE-firm's overall performance. Achleitner et al. (2010) came to other results claiming that the leverage effect is significantly higher for larger deals. In smaller deals revenue growth plays a more important role in terms of value creation. This goes in hand with the fact that larger companies have a higher lending capacity as they are less risky (Nikoskelainen and Wright, 2007). Achleitner et al. (2010) also report that those transactions that were done between 2001-2005 rely more on the leverage effect, and have a significantly shorter holding period than the deals completed between 1991 and 2000. Obviously, value creation for larger deals depends more on financial leverage since the tax benefit has relatively more impact. When looking at industry diversification, results show that all PE-firms except one had invested in various different industries, yet, the performance results of the companies in the sample were strongly dispersed. These findings would - in contrast to the findings of Loos (2005) - lead to the conclusion that superior value creation does not depend on whether they are big or small, diversified or industry-focused. So, there have to be other characteristics that differentiate above-average PE-firms from the rest of the industry. Another structural factor of possible value creation is deal size. Achleitner et al. 
(2010) compared smaller to larger deals by separating between enterprise value over and under EUR 100 million based on the definition for large deals used by Acharya, Hahn, and Kehoe (2009). When looking at EBITDA growth it seems that smaller deals achieve value creation mainly by an increase of sales. For larger deals sales figures are hard to increase but margin improvements can make a big difference and contribute to performance improvement. This assumption is supported by the fact that smaller companies have a substantial growth potential, whereas large companies often have high potentials for improvements by restructuring and cost-cutting.

\subsubsection{Regional Expertise}

In affinity with the IESE and BCG (2010) study about factors of value creation, the issues of regional expertise and geographic expansion should be mentioned. Understanding and handling regional complexities is another key for value creation. It is not surprising that different countries apply different management cultures. Restructuring a business in Europe already requires different skills than managing a business in North or South America. Not to speak of differences between former Soviet countries or Asia, which are completely different to handle, there are always risks and opportunities involved when investing in particular markets. Especially family companies have deep roots in local markets and can be seen as regional experts, yet, often they are limited to their region since they may lack the management and investment requirements to go international. For limited partners of PE-funds regional expertise has become an important issue.

There are stories of "money burners" where fund managers moved and invested into regions where they have no track record, no local experienced team and no business network. Usually PE-houses are very critical about new regions and they know that potential success requires the needed local expertise. Global and mature PE-firms establish partnerships with local firms when they enter new regions.

\subsubsection{Track Record and Experience}

In the study of IESE and BCG (2010) a limited partner stated "Never do it for the first time," concerning his investment criteria in Private Equity. He does not invest either in new funds or in PE-firms with new Managing Partners unless there is a personal track 
record of success. It is relevant experience that makes the difference which PE-fund a LP chooses. Empirical evidence by an analysis conducted at St. Gallen University (2005) investigating 1,130 PE-transactions proves that the highest positive correlation concerning IRR performance - among many factors - was the number of previous PE-deals. Additionally to the mentioned studies numerous other scientists [Barry et al. (1990), Lerner (1994) Gompers (1996), Jelic et al. (2005)] have examined the relationship between PEinvestment performance and the experience of PE-firms. In the study of Acharya, Hahn and Kehoe (2009) the picture emerges that very successful and mature PE-houses create value in their portfolio companies through business-turnarounds improving margins substantially and sustainably. Also in studies by Lerner, Schoar and Wong (2007) and Gottschalg and Phalippou (2005) it is reported that there is a strong learning and performance persistence. Running a PE-fund requires skills that cannot be learned theoretically. This is proven by the fact that inexperienced funds have lower performance. If investors obtain the right to participate in the future in better performing funds by having participated in inexperienced and poorly-performing funds, this could be seen as a learning channel. This so called learning channel could explain the average poor performance for the young PE-industry. The results in their study say that large differences in skills explain differences in performance across investor types. According to their interpretation, this would be a second learning channel explaining poor performance by investors' learning costs. It is known that performance disclosures are rare in Private Equity but they might become more frequent in the future. As a result, learning will be faster and future performance will be better than during the last 25 years.

\subsubsection{Value Creation by Changes in Corporate Governance Structures}

When looking at value creation in portfolio companies by changes in corporate governance structures through the PE-houses, important topics to be discussed are board constellation, management power, evaluation and exchange of management and especially incentive systems. The following chapters provide an overview of the relevance of these topics. 


\subsubsection{Evaluation and Change of Management}

Empirical research by Lawler et al. (2002) proves that companies evaluating their top managers on a yearly basis produce a superior return on investment than those companies in which top managers are not regularly evaluated. After the acquisition of a company PEfirms as "new" owners should require a performance evaluation of the management of the “new” portfolio company by a Management Audit consulting company. With an analysis of the top management (“job-man fit”) one can see the capabilities and fitting of the top management. Different types of managers are needed for different business situations. A growth scenario needs other management skills than a cost-cutting situation. Senior Partners of PE-houses should have good judgment-skills but, additionally, there are consulting companies specialized in Management Audits. The various methods applied include competency-based structured interviews, personality profiling, ability testing, team observations, 360-degree feedback and reference checks. Important facts of management assessments are not only the outcome but the necessary consequences that have to follow. That does not necessarily mean exchanging managers but includes various options such as approval of capabilities, development or modification of responsibilities. Many companies are managed poorly because owners are afraid of change, they do not see the need for better managers and they wait too long to find out about manager's poor performance. Additionally, they are afraid to admit that they have chosen the wrong people for important positions.

A study conducted by Helfat and Bailey (2005) reveals that there is a significant positive correlation between company performance and the replacement of managers with outsiders. Therefore, management teams of portfolio companies have to be assessed according to the business strategy of the company. Practice shows that many PE-firms work with management evaluations after acquisitions, but often they replace top managers too quickly without considering other factors such as the macro-situation of industries and economies. Additionally, it can be said that rapid exchange is often contra-productive to value creation.

\subsubsection{Management Incentives}

PE-firms acquire companies, fix problems, create growth, implement business discipline, create value, and sell the fixed companies for a higher price than what they paid for it. It is 
somehow surprising that in many cases companies only start improving performance when PE-companies enter into ownership. That is especially the case when companies are not able to create growth on their own or when they are close to bankruptcy. What is the reason why many companies are unable to fix their problems without support of Private Equity? According to Leslie and Oyer (2009), and as economic theory suggests, PE-firms solve the managerial agency problem by improving a firm's management. How do they improve management besides exchanging managers? Private Equity uses the effect of managerial ownership to solve the managerial agency problem, which is further explained in chapter 2.1.7.

Leslie and Oyer (2009) are two out of many scientists [Muscarella and Vetsuypens (1990), Baker and Wruck (1989), and others] who examined the changes in managerial incentives caused by PE-companies. First, one has to do differentiate between ownership of managers of public companies and those of PE-portfolio companies. In both cases managers have stock options and incentive plans. Kaplan (1989a) was the first one to test differences in the share of management equity ownership between publicly traded firms and firms that are PE-portfolio companies. The findings of Leslie and Oyer (2009) explain that incentives of top managers are much stronger in PE-owned companies than at comparable publicly traded companies. Their investigation underlines that well paid executives in PE-owned firms own - on average - double the equity stake in comparison to their counterparts in a publicly traded company in the same industry. In addition to that, base pay is 12 percent smaller and variable pay is significantly higher. Since these differences in compensation do not exist before the entry of Private Equity, one can assume that these differences are the result of PE-ownership. Management incentives like an equity stake in the company are not based on a short-term performance as it is the case in many publicly traded companies. In PE-backed portfolio companies incentives are only paid out after selling the company. Hass (2009) mentions that equity incentives should additionally enhance cultural changes in companies with the result that everyone acts in a way that the company needs to produce a return on capital for its shareholders. The time horizon is of importance since managers receive responsibility for their own investment over the complete holding period. The option of leaving the company before the exit of the PE-firm would not make sense since it creates a personal financial loss. However, the most important aspect of equity programs is that managers are required to contribute their own capital meaning that managers have to commit their own funds. Therefore, equity sharing cannot be seen as a kind of 
compensation of managers but rather as an investment or asset allocation of managers. That is one of the main pillows the PE-business model is built on since it transforms managers from agents into owners. The active ownership approach of PE-firms including the active supervision of management's decision-making involves the setting of targets such as financial results and progress achieved in implementing the strategic initiatives developed in joint-work between the PE-professionals and the management. PE-people need to understand the status progress of the portfolio company in order to motivate the management to reach their milestones. Some interesting figures are presented in the research of Acharya, Hahn, and Kehoe (2009). PE-firms - on average - own over 70 percent of a deal's ordinary equity (not considering the debt invested), while 14.6 percent of the remaining ordinary equity is used for incentive purposes. The CEO owns 5.7 percent of ordinary equity and the rest of the management team gets 8.9 percent. When looking at total equity the CEO gets 1.2 percent of the deal value and the rest of the management team gets 1.8 percent. The finding of the above mentioned scientists reveals that the top management gets on average a cash multiple of 13.5 on their cash investment in the deal. These numbers show the power of equity incentives and their motivation increase for value creation. To conclude this chapter it should be mentioned that in general private and public corporations have improved their management and business model very much over the last few decades. Nowadays - also by employing consulting companies on a regular basis companies are on average better managed than during the 1980s and early 1990s. In the United States and most European countries, top management teams of publicly listed companies and partly also those of family owned businesses own some of the equity in order to guarantee alignment of interests.

\subsubsection{Supervisory Boards}

In general, the importance of boards depends on company size and on cultural factors. Therefore, boards have different levels of influence depending on company constellations such as public companies, family companies, and portfolio companies of PE-houses. Depending on the jurisdiction, companies have more or less strict legal guidelines in terms of size and allowances of their boards. Part of the business model of PE-firms is to control the boards of its portfolio companies. 
Literature [Guest (2009); Eisenberg, Sundgren, and Wells (1998); Yermack (1996)] suggest that there a large difference in the efficiency of the boards of PE-backed firms compared with those peer companies of public and family nature. One of the major reasons for that could be that PE-houses do offer support to the activities of the boards of their portfolio companies. In addition to that, management incentives enhance the motivation of involved board members. Supporting activities by the PE-firms include the engagement of external industry and functional experts. Studies have proved that the size of boards is another factor for the efficiency of decision-making. Smaller boards are obviously more efficient and decision-making is done at a faster pace than in other forms of companies.

Empirical research by Yermack (1996) proves that companies with boards of five to seven members show better performance than peers with larger boards. Hass' (2009) comprehension of Board size is similar to Yermack’s (1996) study. The number of board directors should be kept small ranging from 4-6 in order to focus on value creation. Boards that are strong in value building are characterized by the approach of developing an economic view of companies. They consider values such as Return on Capital, alternative uses of capital, time value of money, and Economic Value Added. Not only do they focus on the above described values, furthermore, they also spread their view to all stakeholders. Anyhow, only calculating these Key Performance Indicators (KPIs) is not of any help if relevant change in the company culture does not follow.

Becht, Bolton and Röell (2002) have observed that PE-firms sometimes make use of the practice to install a separate shareholder committee in case that it is not possible to downsize the number of board seats. PE-companies are also inclined to determine the agenda of board meetings and the extent to which board members engage in the portfolio company.

In one particular study, Brick and Chidambaran (2007) examined that boards of PE-backed companies spend substantially more time on operational business strategy than the boards of public companies. This could be explained by the fact that public companies have to cover strict accountability requirements and they have to follow bureaucratic structures. That is why public companies often waste time on non-strategic issues such as compensation, benefits, compliance and auditing.

According to Loderer and Peyer (2001) boards of top-performing companies meet on average 9-10 times per year. The often heard problem that board members serve in various 
boards should be avoided in order to avoid conflicts of interest and to guarantee sufficient overview, focus, and efficiency. The practice in Private Equity is that appointments to the board cannot be decided by the CEO whereby former CEOs are generally excluded from the chairman position.

In their study "Corporate Governance and Value Creation - Evidence from Private Equity" Acharya, Hahn and Kehoe (2009) conducted a profound research on board structures and board meetings. Their finding says that the typical board structure of a portfolio company has about eight members with 33 percent of them coming from the PE-company, which are usually those PE-directors directly involved in the deal. 43 percent of the board members are part of the management team, and the rest of the seats are allocated to other people. As far as board meetings are concerned, their report says that there is at least one board meeting a month in 68 percent of the PE-portfolio companies. In 92 percent of the deals PE-directors have informal interactions with their CEOs during the first 100 days on a weekly basis. The study claims that on average 1.5 PE-managers are involved with new deals. After the first 100 days the time commitment of the PE-funds is declining to an average of about one PE-manager assigned to four portfolio companies. To sum up the above mentioned study, it can be said that PE-partners meet on a weekly and informal basis with the management. These meetings occur more often in the due-diligence phase and during the first 100 days after the acquisition when value-creation plans are modelled and first major changes are implemented.

Cornelli (2008) has looked at the size, composition and evolution of boards over time. His finding that the role of the board is crucial in Private Equity confirms results by other authors. Studying the boards is a good way to observe how PE-professionals effectively restructure a company. Having private equity partners on the board of a company is very helpful for success in restructuring a company. For PE-firms there is, of course, the opportunity cost of being actively involved in the board of a company means having less time to focus on other deals. The successful turnaround of portfolio companies is the result of time and effort that PE-firms put into the process, so PE-firms choose to use their resources in the deals they expect to be more successful. 


\subsubsection{Operating Partners and Industry Specialization}

This chapter [based on literature by Matthews, Bye and Howland (2009); joint study of IESE and BCG (2008); Acharya, Hahn, and Kehoe (2009); Pappas, Allen and Schalock (2009)] starts by explaining which role industrial partners have in Private Equity and which advantages they bring to the PE-business model. In Private Equity there is one strategy that never changes unrespectable of deal size, fund size, industry focus or by any other factors. This one key strategy and business model of Private Equity is the ability to improve the performance of portfolio companies on a sustainable way to perform a successful exit. Reaching this aim requires access to people who:

- know one specific or various industries like the back of one’s hand

- have senior experience managing a company or a group of firms

- helpfully understand the private equity process, strategy and execution

That is why these so called "Operating Partners" should be individuals with experience in executive positions in the industry, finance or consulting world. Their tasks in the PEprocess reach from information-gathering about industry trends and rumours, pre-duediligence by visiting potential targets, support in the transaction process and supervisory function in the acquired companies. Let us start first have a look at the so called "network access”, which is the capability of becoming an industry insider in the sectors, in which they operate. Operational Partners are usually very well connected with the relevant industry and its players. These industry networks give the PE-top performers a starting advantage in potential deal flow allowing them to identify successful deals. Nowadays, an increasing number of PE-target companies come through established networks in particular industries. After the identification of promising targets, the industry insight by Operational Partners additionally allows to be stronger in the bidding process than competitors.

The IESE and BCG (2008) study provides the very successful Tognum-deal as an example of how industry network access applies in real life. The diesel-engine manufacturer Tognum (formerly named MTU Friedrichshafen) was acquired by the EQT-Partner from DaimlerChrysler in March 2006. EQT-Partners had a network of highly knowledgeable internal and external advisors including the former CEO of Mitsubishi Motors Corporation as well as former top managers from Atlas Copco and ABB. Due to the network of these former top managers EQT-Partners heard about the Tognum sale months before the official 
bidding process started. This time advantage allowed the PE-house to develop a detailed market analysis of the industry, a pre-due diligence of the target's potential, and a future strategy for the company. Entering the bidding process with a detailed strategy for Tognum and the suggestion that the - above named - Operating Partners of EQT-Partners serve on the Tognum board impressed the sellers and Tognum's board of directors. Their professionalism and credibility together with the readiness of the PE-house to start the transaction process with DaimlerChrysler made them winning the deal. Besides being insiders in industries Operational Partners also undertake an operational role in the strategic planning and supervision of portfolio companies. Either in the function as board members or as external consultants they use their industry knowledge and analytic skills in strategic issues for the purpose of performance improvement. Their advantage ranges from having a senior management experience to the additional contribution of having a much broader experience than most CEOs since they are used to work with multiple portfolio companies in different industries. The best Operating Partners are better than any consulting company since they identify and apply best practices from various companies and industries. They provide a different perspective to the management since they are not focused on daily business and operational issues. Moreover, they bring in their own expertise together with the ideas of the PE-organization and - usually - support the management without taking away the power of the management team. Another role of Operating Partners is the support of management vis-à-vis the PE-firm. Very often, even top managers are naïve concerning the realities of PE-ownership concerning their rights and their equity stake. Executives have to get used to work closely with a PE-house and they need training for that. Also the new situation of living in a PE-environment and the following consequences such as higher cash flow discipline, ongoing operational improvements, reporting to the PE-owner and a faster pace in general is not easy to handle. The incentives for Operational Partners are usually very high since their impact is of major importance and the role is very complex having many stakeholders and different interests involved. One Operating Partner described his role as being “... an entrepreneur, teacher, mentor, father, policemen, judge and lobbyist...” Operating Partners also have the function to tell the PE-house and to change things accordingly when portfolio companies are not following certain rules defined before, when managers do not meet targets or when managers make huge mistakes. Nevertheless, Operating Partners prefer to work with existing management teams. Instead of replacing management teams in portfolio 
companies, good Operating Partners motivate senior managers to take ownership of value creation actions. It may also occur that the Operating Partner evaluates the current management team and concludes that management is part of the problem.

The Operating Partner model has a long history in the PE-industry, but the details of the concept vary according to fund size and the needs of individual PE-firms. In earlier days, PE-firms were criticized for having only financial engineers on their portfolio company's boards, so they engaged more and more industry experts on their teams. Nevertheless, when asking limited partners about the efficiency of Operating Partners, they give different answers. The spread of strategic involvement of Operating Partners in portfolio companies goes from a formal board seat without impact to a value-builder role in the company. It is challenging to get Operational Partners involved and engaged in operational value creation, but this kind of economic agency problem can be solved with incentives.

Acharya, Hahn and Kehoe (2009) provide some figures about the impact of external support to portfolio companies in the form of Operating Partners. According to their studies, external support is used during the due diligence in 78 percent of the deals, in 29 percent of the deals during the first 100 days, and in 42 percent of the deals in the period after the first year. Some leading and mature PE-firms have even set up their own inhouseconsulting company that is only dedicated to performance improvement projects in their own portfolio companies. Bain and Company is the most well known example of a consulting company that is part of a PE-firm, whereby Bain Consulting also works for other companies nowadays. The advantage of aligning interests in such consulting projects is, again, the incentive system. Managing Partners of PE-inhouse consulting firms do participate in the potential gains; therefore, one can assume that the consulting and implementation approach differs from those consulting companies working on a fixed income basis.

The research of Pappas, Allen and Schalock (2009) indicates that nowadays PE-firms can take two different approaches concerning staffing and specialization. The first approach focuses on functional practice and the second one on investment specialization. As mentioned in the general introduction of the thesis, PE-firms have to change their hiring philosophy by recruiting highly specialized staff from various fields instead of focusing on generalists or financial engineers only. Due to reasons of expensive and limited resources specialization in PE-firms is a trend that correlates high with the size of PE-houses. In 
practice, PE-houses are organized and structured either by investment criteria such as industries, locations and ownership, or by functions such as operation groups. In those PEfirms with more than 50 people, 67 percent are organized by investment focus. Among PEfirms with about 20 people, 71 percent are organized by investment specialization and among PE-firms with 21 to 50 people, 63 percent of them are similarly organized. Literature suggests that specialized PE-firms are on average more than twice the size of generalist PE-firms with less specialized industry professionals. Firms in Private Equity pursuing a generalist model make have about 27 percent market share in the mid-size PEmarket.

\subsubsection{Value Creation by Strategic and Operational Improvements}

Besides value creation by changes in corporate governance structures of portfolio companies, this work also investigates value creation by strategic and operational improvements. Operational and strategic value creation is a more recent practice in Private Equity than the change of corporate governance, which has always been a part of performance improvements. Various authors such as Achleitner (2010); IESE and BCG (2009) indicate that the capability of operational improvement is essential in PEperformance for the coming decade. The following chapters delve into topics such as strategy, 100 day plan and possible methods of operational improvements.

\subsubsection{Strategy and 100-day plan}

In family owned businesses as well as in listed companies owners and managers engage in strategy discussions. Normally, organizations do neither create nor change strategies very much on their own. The formulation and implementation of a new strategy often follows special circumstances such as a crisis threatening the company's existence or the guidelines by new owners (Hass and Pryor, 2009).

According to limited partners of Private Equity the implementation of a new strategy is after the evaluation of management - the second most important task in value creation by PE-owners. PE-firms should always use the momentum of change in control in order to 
implement their new strategies (Applegate, 2007). New strategies are developed and implemented in the so-called "100-day plan" or "full potential plan". As it is explained by Matthews, Bye and Howland (2009), many PE-houses prepare the 100-day plan as detailed as possible in advance of the deal-closing. A 100-day plan has to be as specific as possible, especially in explaining how the PE-owner plans transform a company from its status-quo to an enhanced state in the future. The efficient planning and execution of a 100-day plan differentiates successful deal partners from those with less returns. Typical 100-day plans in Private Equity focus on common goals such as market share gains, growth plans and cost reductions as well as on PE-specific goals such as EBIDTA, return on capital and debt paydown schedules. Within the plan, a set of key performance indicators is developed to track the performance on a regular basis. Once developed, the plan is subject to continual review and revision. For the implementation, control and success of the developed goals, Operating Partners play an essential role. First, by knowing the industry they help to set achievable goals. Secondly, they support the management in implementing the required changes and in meeting the planned schedules. Often during the implementation of these plans, Operating Partners - together with the management - detect more potential of operational improvements. The challenge is to rank the potential projects in priority order, and select those major projects that they need to do first. According to the study of Heel and Conor (2005), firms implement such a performance-management system in 92 percent of the best-performing deals and only half as often in the worst performing deals.

\subsubsection{Operational Improvement}

In Private Equity, value has usually been created by financial leverage, by changes of the corporate governance structures of portfolio companies as well as by hiring Operating Partner for certain industries. Due to various reasons these above mentioned value creation drivers are not longer sufficient to convince LPs and to be successful in the industry.

According to various literature sources [Achleitner (2010); Matthews, Bye and Howland (2009); Kaplan and Stromberg (2008)], the decade of “Operational Improvement” has emerged as it is shown in figure No 13. 


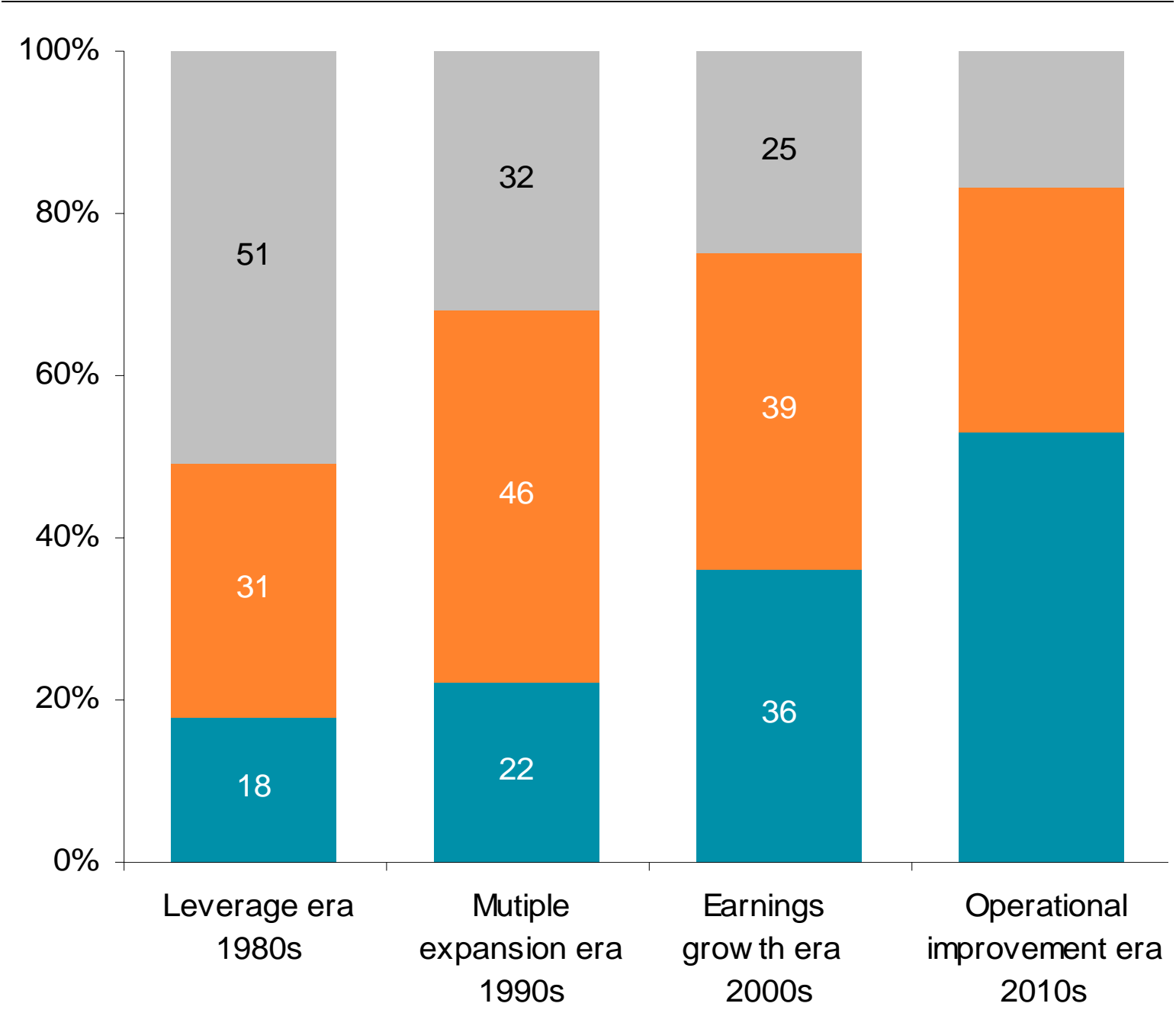

Figure No 13: Decade of Operational Improvement - Way of Creating Value has changed over Time (compiled by BCG)

Operational improvement is the capacity to acquire a target company and to improve operations substantially after the successful acquisition. Since PE-houses want to create real and sustainable values (not only for the financial statement) the capability of operational improvements is critical. Former investment bankers rarely have the experience and capability to turn around businesses, so people with backgrounds in consulting and operational management are required. These people need to bring considerable experience in managing companies and systematically improving their performance.

After PE-deals are closed, the planning of operational improvements starts. Specialized PE-professionals work very closely with the management of their portfolio companies to plan the improvement agenda, develop a restructuring or turnaround program, and install 
operating-metrics, which are called “dashboards”, in order to measure actual performance against developed goals.

The BCG and IESE study (2008) provides a good example of how PE-firms could create value by their operational improvement capabilities. In 2000, a consortium led by Allianz Capital Partners acquired the German packaging company Schmalenbach-Lubeca. The mentioned PE-house worked very closely with the CFO and the other top managers to conduct an industry analysis (benchmark and best practice analysis) in terms of the company's financials. The results of the analysis revealed that working-capital productivity is an area for quick improvements and value creation. The story behind that is that the company - before it had been taken private - could easily get cheap internal loans from VIAG, its public-company parent, to finance the required working capital. Since money was there, there was no need for managers to care about working capital as an expense to be managed. Already before the deal had been closed with VIAG, Allianz Capital Partners mentioned in the Share Purchase Agreement (SPA) to replace the existing loans with external bank debt. Another step to fix the explained problem was the shortening of the company's working capital cycle. This measurement is often used by PE-houses to put pressure on debt repayments and to create the need to reengineer business processes, so that faster working-capital cycles create the urgency to improve operational efficiency. The result was that the new savings created by higher efficiencies allowed the company to pursue an inorganic growth strategy without new credits. This double effect of increased efficiencies and successful growth allowed Allianz Capital Partners to exit very successfully in 2002.

According to Acharya, Hahn, and Kehoe (2009) value creation initiatives consist of productivity improvements as well as of organic growth. Productivity initiatives can be applied in the following process fields:

- Purchasing (e.g. supplier consolidation)

- Process efficiency (e.g. supply chain)

- Overhead reduction (e.g. Sales, Admin Costs)

- Working capital reduction

- CAPEX reduction 
Organic Growth initiatives may consist of the following levers:

- Review of pricing

- New sales channels

- New products

- New geographies

- Existing geographies, new customers

- Existing geographies, existing customers

Also Matthews, Bye and Howland (2009) explain that PE-firms have to focus - more than ever - on their core-ability to improve operational and organizational performance in every portfolio company in order to achieve their investment goals. As their study indicates, only few PE-firms have proven their ability to achieve operational improvements in their portfolio companies consistently over a longer time period. Already during the 2004-2007 credit boom, above average success of PE-deals was - on average - more based on operational improvements than on financial engineering.

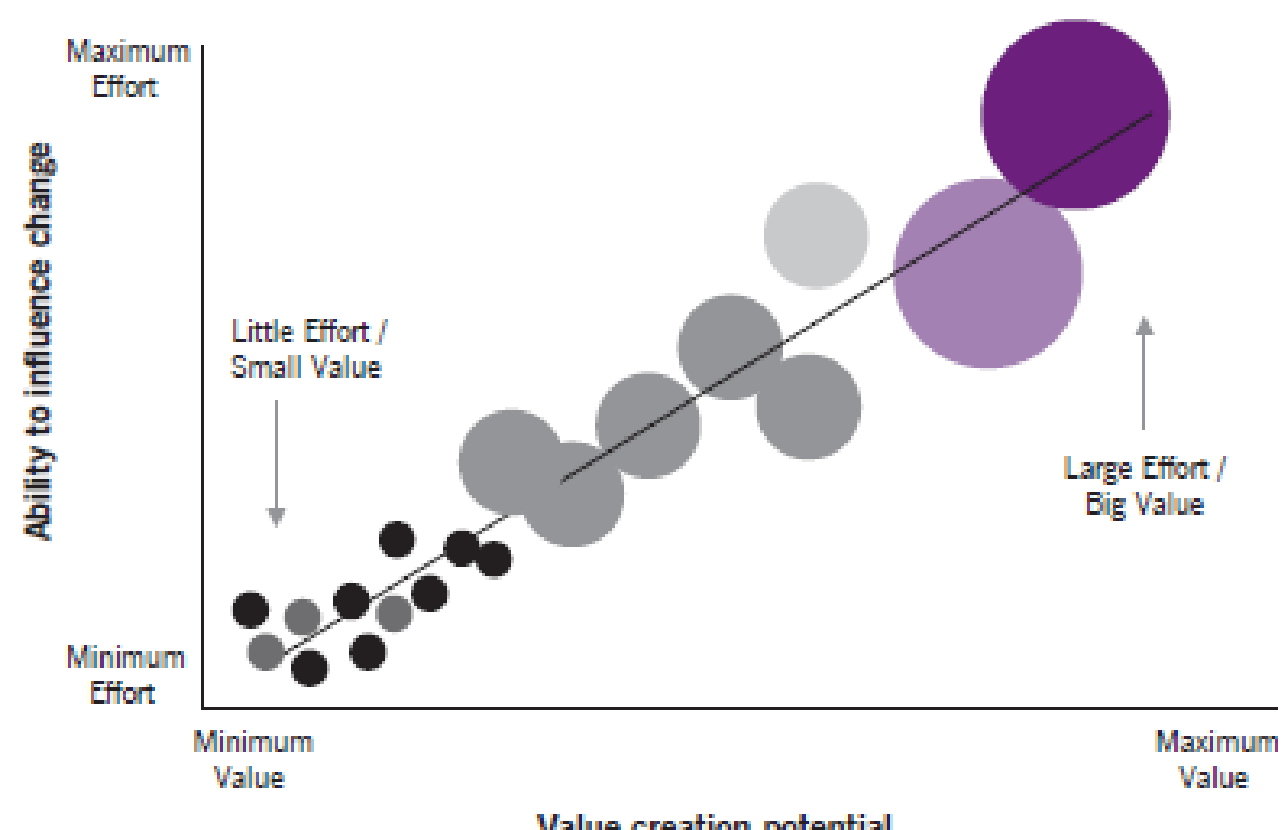

Figure No 14: Right Selection of Initiatives (compiled by Matthews, Bye and Howland (2009)) 
Another area of potential improvements in a portfolio company concerns the organizational structure. The study "Managing For Value - How the World's Top Diversified Companies Produce Superior Shareholder Returns”, conducted by BCG directors Heuskel, Beckmann and Fechtel (2006), focuses on value creation by lean organizational structures with clear responsibilities. The study shows that underperformers usually have a more complex structure than outperformers. Eighty percent of the underperformers and 5 percent of the top players work within a three-layer structure, which is structured in headquarter, sub-holdings, and the business units themselves. Only 20 percent of the underperformers have a two-layer structure, compared with 45 percent of the outperformers. The fact that many long-term outperformers, such as GE, Toyota, Honda, etc., have adopted their organization to lean structures supports the above mentioned study. It goes with growing size of organizations how much value lean management creates. The more diversified the business, the greater the relevance and value of a lean structure. In the mentioned study, two ways to develop a winning organization structure are worked out. First, it is necessary to stay lean, and, secondly it is of essential importance to define the roles and responsibilities of headquarter and each business unit.

\subsubsection{Operating Measurements}

When discussing value creation in portfolio companies initiated by PE-ownership, one has to deepen into the different kinds of measurement of value creation. The following chapter focuses on metrics of value and how value is measured in the practice of Private Equity industry. Practice and Literature [by Brigl et al. (2008); Pindur (2007); and Loos (2006)] suggests that there are three basic value creation drivers:

- EBITDA growth

- EBITDA multiple expansion

- debt repayments

Often EBITDA growth is further split into sales growth and EBITDA margin improvements. As already explained in the chapter of studies on transaction levels, Achleitner et al. (2010) differentiate between the levered and the unlevered return of capital in order to calculate the contribution of the leverage effect to value creation. 
In other words, the aim of their study was to find out how much of value creation came from the leverage effect and how much from the operational improvements and multipleeffects. They further divided the unlevered return into three value drivers:

- EBITDA growth

- free cash flow (FCF) effect

- multiple effect

The contribution of EBITDA growth to value generation is the difference in EBITDA between entry and exit multiplied with the EBITDA multiple at entry. The FCF effect stems from the free cash flows, which can be used for paying down debt and for financing dividends, generated by the portfolio company. The multiple-effect is an exterior effect since it is given by industry valuation standards. It is about the difference between entrymultiple and exit-multiple multiplied with the EBITDA at entry. Pindur (2007) suggests that a correction factor has to be used for the calculation of simultaneous changes in EBITDA and EBITDA multiples. In practice, the combination factor is often not shown since it is either attributed to the EBITDA or the multiple-effect. When analyzing the value lever "EBITDA growth", there are two drivers which can also occur simultaneously. One driver of EBITDA growth is revenue growth and another one is change in. By increasing both, revenues and EBITDA margin, value creation would be ideal. 


\section{CASE Study}

\subsection{Introduction and Methodical Approach}

By reading relevant literature about value creation in Private Equity, it became clear that a case study would be of great support for a better comprehension of the thesis that “Active Portfolio Management Creates Value in Private Equity”.

The case study aims at better understanding the connection between active portfolio management and value creation, which is measurable in real life case studies due to the gain made by selling the companies. Due to lack of time and data, a more comprehensive statistical significant study could not be conducted. Nevertheless, the case study illustrates in a representative way how sustainable value can be created by using some triggers. Before delving into the ownership approach of DBAG, the case study companies are explained in detail. Explanations concerning the effect of value creation and general conclusions are explained in the chapters following the description of the companies.

\subsection{Private Equity Company Deutsche Beteiligungs AG}

Deutsche Beteiligungs AG (DBAG) is a leading German private equity company with a history of over 40 years and more than 300 transactions in German speaking "Mittelstand" (medium sized) companies. DBAG has an investment focus on companies whose business models are rooted in the outstanding quality of their products and associated services. Such enterprises are often positioned in the mechanical and industrial engineering sectors, in the automotive supply industries and other industrial fields. In these industries the PE-firm has extensive experience how companies operate and also maintains a strong network. DBAG looks especially for companies having outstanding positions in their markets either due to their products and services or due to a niche market position. The PE-company also acts as a management company of entrusted assets that it invests through co-investment funds. The distinct investment focus lies on management buyouts of growth-driven, profitable, internationally operating companies. (www.deutsche-beteiligung.de) 


\subsubsection{History}

In 1965, DABG was founded to provide equity to SME in Germany playing a pioneering role by offering Private Equity to German companies. About 20 years later, "Deutsche Beteiligungs AG Unternehmensbeteiligungsgesellschaft” was founded by Deutsche Bank and the banking business of Karl Schmidt. Deutsche Beteiligungsgesellschaft mbH conducted the business operations of Deutsche Beteiligungs AG as its management company. In December 1985, preferred shares of DBAG were traded for the first time on Frankfurt and Düsseldorf stock exchange. The company's subscribed capital of DM 30,000,000 was divided equally into common and preferred shares, whereby non-voting preferred shares were offered at a subscriptions price of DM 140. The German law on Private Equity became effective on January 1987, which led to the creation of equity investment companies. PE-businesses received the status of an equity investment company exempted from municipal trade and capital tax. The company is required to be listed on the stock exchange within a defined period of time, and the charter shareowners must pass on part of their shares. The Amendment to the German PE-legislation in 1995 enabled Deutsche Beteiligungs AG to invest in international businesses. As of November 1996, Deutsche Beteiligungs AG employed its own staff. The management team that had previously managed the business of Deutsche Beteiligungs AG through Deutsche Beteiligungsgesellschaft $\mathrm{mbH}$ transferred to Deutsche Beteiligungs AG. In September 2003, DBAG completed the fund-raising on the buyout fund DBAG Fund IV with a sum of EUR 228 million committed by institutional investors. Two years later in 2005, DBAG raised another co-investment fund - DBAG Fund V - with a size of EUR 375 million. Additionally to the DBAG Fund V, the DBAG Fund V co-investment fund achieved commitments of EUR 434 million. In 2007, when the DBAG Fund V began its investment phase, Deutsche Bank as major shareholder withdraws completely meaning that 100 percent of DBAG shares are in float ownership for the first time. (www.deutschebeteiligung.de) 


\subsubsection{Industries and Transactions}

Industry Focus:

- $\quad 45.5$ \% Plant Engineering \& Engineering

- $7.5 \%$ Consumer Goods

- $\quad 42.3 \%$ Industrial Services \& Logistics

- $4.7 \%$ Others

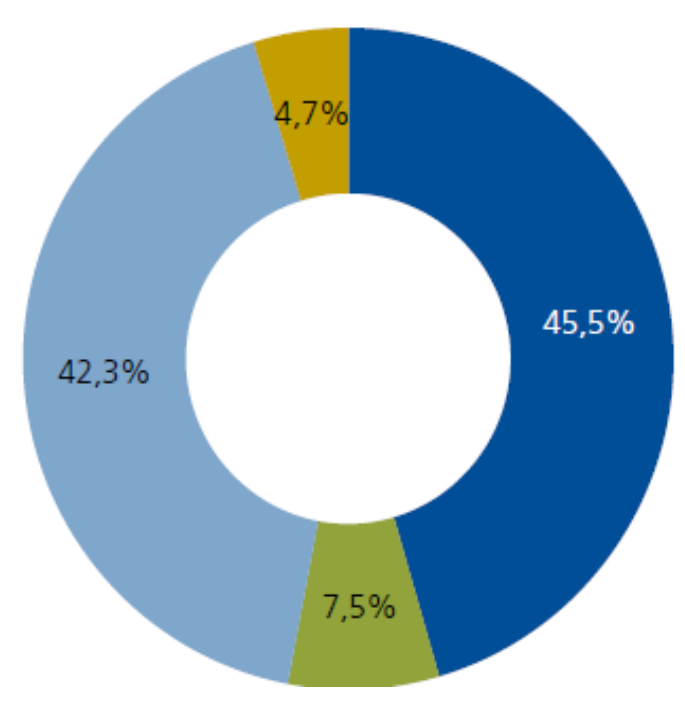

Figure No 15: Industry Focus of DBAG investments

(compiled by DBAG)

Transactions by Industry Sectors (a total of 32)

- 10 Mechanical and industrial engineering

- 5 Industrial services and logistics

- 5 Automotive supplies

- 1 Speciality chemicals

- 1 Measurement and automation technology

- 10 Others

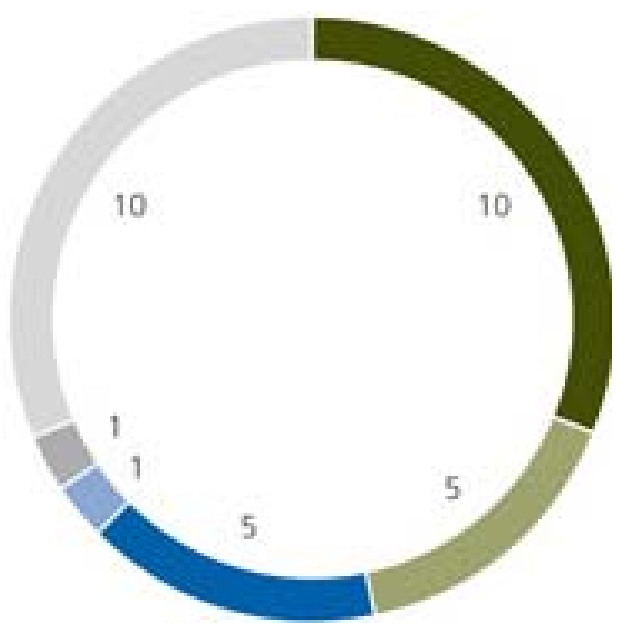

Figure No 16: Transactions by Industry Sectors from Nov 1996 to October 2009 (compiled by DBAG)

\subsubsection{Shareholder Structure}

The Shareholder structure has changed significantly over the last few years with following a reduction of international institutional investors. Shares held by international institutional investors decreased from 35.3 percent to 28.0 percent within only one year. 
DBAG states that it welcomes the fact that shares are increasingly in the portfolios of funds that exclusively invest in listed PE-stocks. German institutional investors hold 17.8 percent of the shares and 43.6 percent were in private ownership. More than 10,000 private investors are shareholders of DBAG shares.

- $\quad 43.6 \%$ Private Shareholders

- $10.6 \%$ Dirk Roßmann

- $\quad 17.8 \%$ Institutional Investors Germany

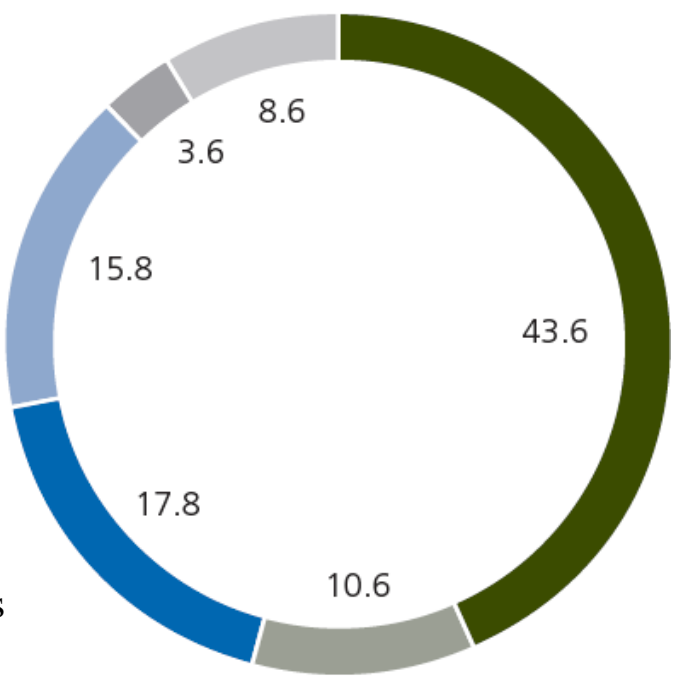

- $15.8 \%$ Institutional Investors U.S.A.

- $\quad 3.6 \%$ Institutional Investors U.K.

- $8.6 \%$ Institutional Investors other countries

Figure No 17: DBAG Shareholder Structure (compiled by DBAG)

\subsubsection{DBAG Performance}

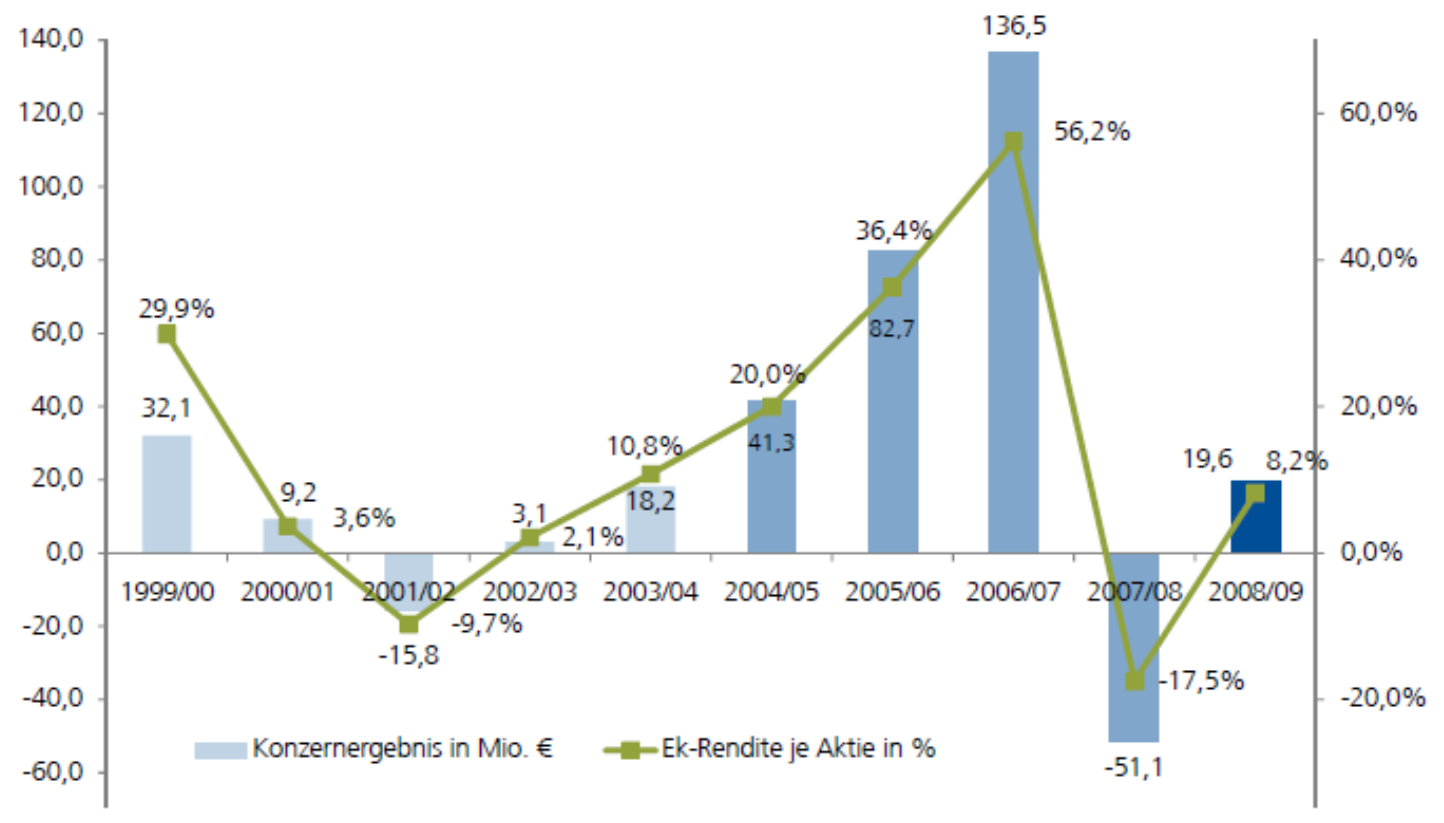

Figure No 18: 14 percent on a 10 year average ROE per DBAG-Share (graph compiled by DBAG) 


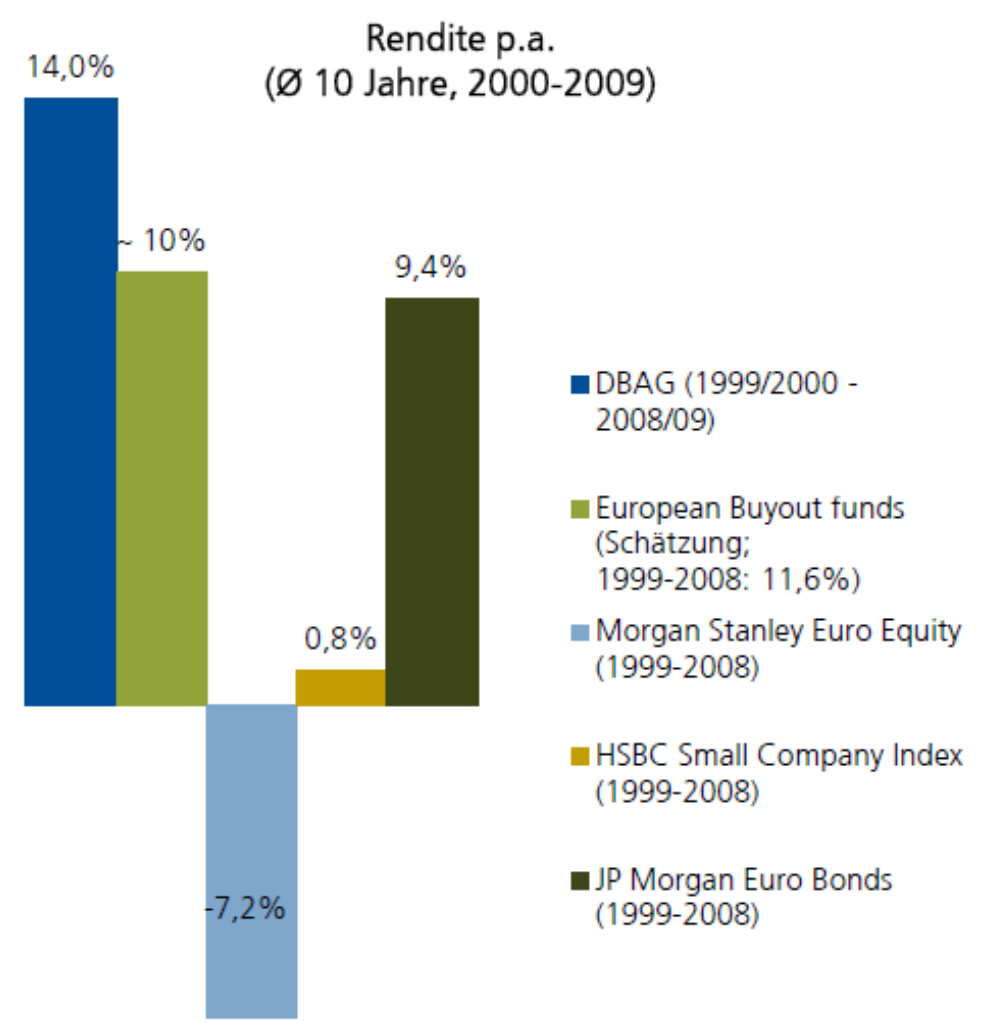

Figure No 19: ROE of DBAG outperforms Other Asset Classes (graph compiled by 2008 Pan European PEPerformance Benchmark Study, EVCA Paper-June 2009)

\subsubsection{The DBAG Share}

\begin{tabular}{|c|c|c|c|c|}
\hline \multicolumn{2}{|l|}{ Share data } & \multirow{2}{*}{$\begin{array}{r}2008 / \\
2009 \\
15.55\end{array}$} & \multirow{2}{*}{$\begin{array}{r}2007 / \\
2008 \\
10.45\end{array}$} & \multirow{2}{*}{$\begin{array}{r}2006 / \\
2007 \\
24.10\end{array}$} \\
\hline Closing rate & $€$ & & & \\
\hline Financial year high 1) & $€$ & 17.22 & 23.99 & 31.88 \\
\hline Financial year low ${ }^{1)}$ & $€$ & 9.00 & 9.06 & 16.78 \\
\hline Annual performance ${ }^{2)}$ & $\%$ & 54.8 & -46.8 & 57.3 \\
\hline Market capitalisation ${ }^{1)}$ & $€ \mathrm{mn}$ & 212.7 & 142.9 & 347.1 \\
\hline \multicolumn{2}{|l|}{ thereof, free float } & 190.1 & 135.8 & 347.1 \\
\hline \multicolumn{2}{|l|}{$\begin{array}{l}\text { Average daily trading } \\
\text { volume }{ }^{3)}\end{array}$} & 0.370 & 1.244 & 1.793 \\
\hline Dividend per share ${ }^{4)}$ & $€$ & 0.40 & 0.40 & 1.00 \\
\hline \multicolumn{2}{|c|}{ Surplus dividend per share ${ }^{4)}$} & 0.60 & - & 2.50 \\
\hline Distribution sum ${ }^{4)}$ & $€ \mathrm{mn}$ & 13.7 & 5.5 & 47.9 \\
\hline Earnings per share ${ }^{5}$ ) & $€$ & 1.44 & -3.73 & 9.20 \\
\hline Cash flow per share ${ }^{5}$ & $€$ & 0.70 & 0.52 & 3.00 \\
\hline NAV per share ${ }^{6}$ ) & $€$ & 18.94 & 17.90 & 25.09 \\
\hline \multicolumn{2}{|c|}{ Price/NAV ratio per share ${ }^{6}$} & 0.82 & 0.58 & 0.96 \\
\hline
\end{tabular}

Figure No 20: DBAG Share Data (compiled by DBAG) 
After a peak in mid 2007 and strong fall for two continuous years, DBAG-shares made a strong recovery end of 2009. That was due to various reasons. First, the general sentiment on stock markets was gradually improving pushing up DBAG shares. Secondly, the company performed very well in two exits, which also brought a surplus dividend for shareholders. Altogether, the share price went up 49 percent within one (financial) year. On 7 January 2009, the share price closed at EUR 13.43 losing nearly a third of their value. On 3 March 2009, the price was at EUR 9 marking the year's low. From then on until the end of the financial year, the DBAG share price kept increasing gaining 73 percent to EUR 15.55. The year's high peaked on 18 September 2009, with a share price of EUR 17.22. The market capitalisation of DBAG climbed up from EUR 142.9 million in 2007/2008 to EUR 212.7 million in 2008/2009. DBAG shares outperformed all other benchmark indices over the same period. The DAX gained 8.6 percent and the S-DAX 27.1 percent, whereas the LPX50, the benchmark for international private equity companies recorded a loss of 8.2 percent in the same period.

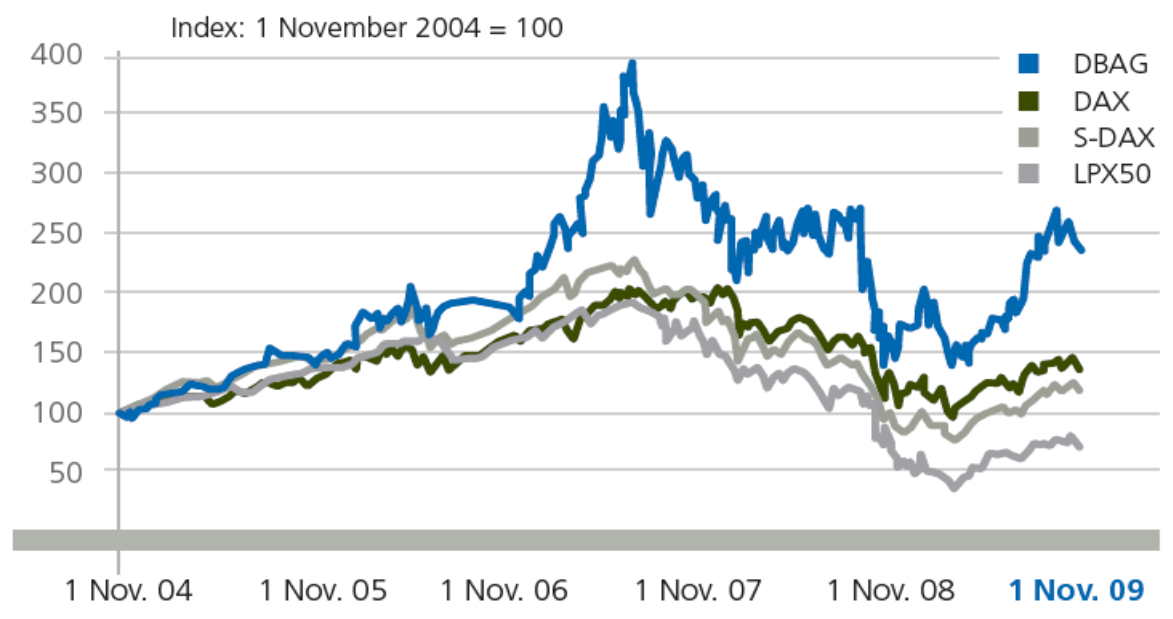

Figure No 21: DBAG Share Performance from 1 November 2004 to 31 December 2009

\subsubsection{Private Equity Index LPX 50}

Shares in Deutsche Beteiligungs AG are a component of different indices that only consist of listed PE-firms. As one of two German PE-firms, DBAG is a member of the LPX50 index. The LPX50 tracks the performance of listed PE-companies and consists of the 50 largest private equity firms worldwide. Criteria for “membership” are - besides some minor factors - mainly market capitalisation, trading volume and liquidity constraints. 
The design of the LPX50 ensures that it is investable, tradable and transparent. The index is well diversified across regions, investment- and financing styles, and also by vintage years. At the end of October 2009, the LPX50 consisted of 23 European companies of which nine are UK-based, 23 American firms and four Asian firms. (www.lpx.ch)

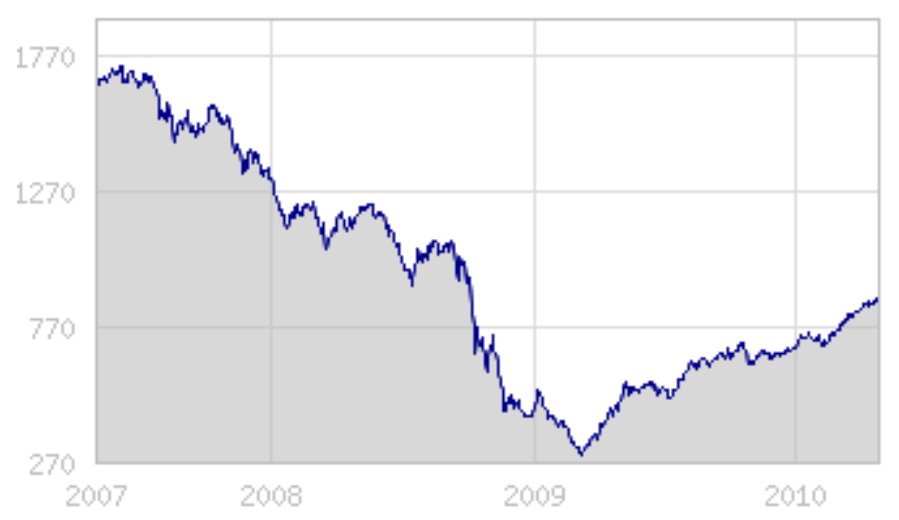

Figure No 22: LPX50 ${ }^{\circledR}$ 3-Year Performance April 2007 - April 2010 (compiled by www.lpx.ch)

\subsection{Portfolio Company MCE AG}

MCE AG serves as a case study example of a passive portfolio management approach by the PE-firm DBAG. Since the case study focuses on the impact of Private Equity, MCE AG is described as it was in 2006 (before DBAG acquired the company in 2007). The information on MCE AG is mainly based on the corporate website (not existent anymore) and on interviews with former employees and managers of the company. MCE AG is an Austrian based company providing construction and services in the fields of engineering, manufacturing, construction and maintenance. The company has a strong regional presence in Austria, Germany and Central Eastern Europe. Due to the size of the company (around EUR 900 Mio turnover and 6000 employees) and due to the high specialization of provided services, MCE AG is one of the biggest three players in Europe. The organizational structure is built up in three business divisions:

- Industrial Services

- Facility Management

- Personnel Services, Engineering and Consulting 


\subsubsection{History and Regional Presence}

The company history of MCE AG is very unique and not typical at all since there is no founding person or family background behind this company. Besides having an IPO, the company has undergone all possible ownership structures ranging from state ownership, Private Equity to finally becoming an integrated part of a leading global construction concern. For a more comprehensive understanding of the corporate development, some historical steps are described in this chapter. The holding company VOEST-ALPINE MCE - part of the VOEST concern - was founded in 1989 as a consequence of the restructuring and privatisation of the formerly "Österreichische Verstaatlichten-Industrie", which was a holding company for Austrian's state-owned industry companies. VOEST-ALPINE MCE, which stands for Machinery, Construction and Engineering, became an independent company, and has developed to a market leader as international provider for hydraulic machines, steel and engineering as well as to a service provider in the fields of industrial maintenance and personnel services. From 1989 until 1998 VOEST-ALPINE MCE has undergone a strong growth period by acquiring and founding several subsidiaries. In 1998 the company was renamed to VA TECH VOEST MCE since the Austrian technology company VA TECH became shareholder of the holding company. In 2001, the U.S. based PE-company Andlinger \& Company, which was founded by an Austrian, became majority owner of the company. In 2002, the same PE-group became sole shareholder and renamed the company to MCE AG. In the further course of the company, various similar businesses - like the Austrian part of ABB - were acquired. Especially the former Mannesmann Anlagenbau Austria companies were integrated and restructured.

As shown in Figure No 23, MCE AG focused on Central Eastern Europe (CEE) as Emerging Markets that were not penetrated by the industrial service industry. By the end of 2006, the company had about EUR 1 billion turnover, but an EBITDA-margin of just 3 percent and a 0.5 percent surplus. Even though, the PE-firm Andlinger and Company made the company independent of other companies - such as VOEST and VA TECH - their PEprofessionals did not manage to make MCE AG a very profitable company. If such a big company with such a strong market presence had been more profitable, an IPO would have been a perfect exit for its owners. 


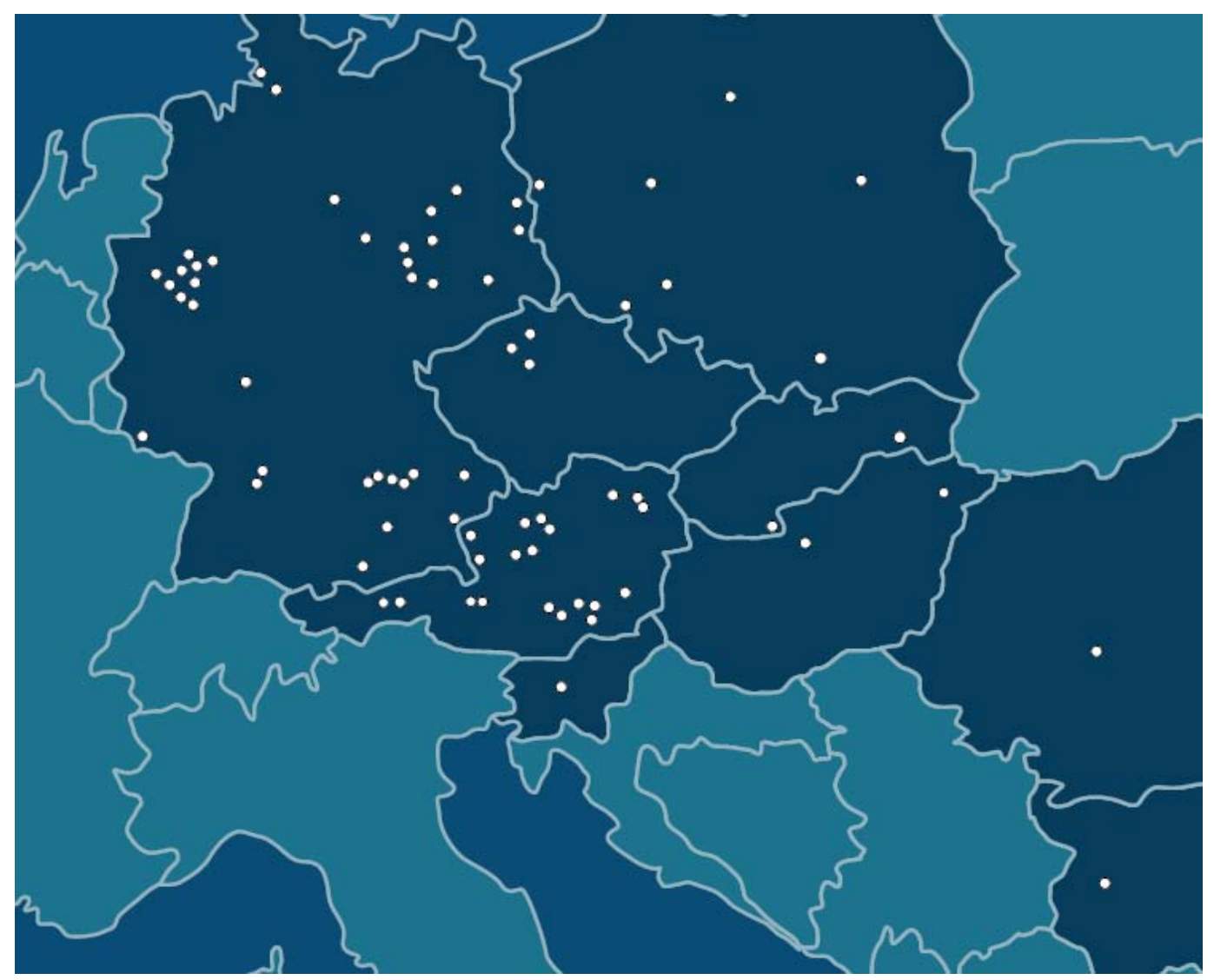

Figure No 23: Regional Presence of MCE AG in CEE (compiled by MCE AG)

\subsubsection{Competitors and Industry Benchmark}

In order to understand if the weak financial performance of MCE AG only depends on the industrial service industry or also on other factors, this chapter looks at the three main competitors of MCE AG to analyse their setup and commercial performance. Due to the fact that the main competitors are all integrated in a concern structure and financial figures are consolidated, it is hard to find the same key performance indicators for each division. Nevertheless, the figures provided in the following three sub-chapters provide a feeling for the financial performance of the industry.

\subsubsection{Bilfinger Berger Industrial Services AG}

Bilfinger Berger Industrial Services AG (BIS AG) is a German industrial service company based in Munich. The company belongs to the German construction company Bilfinger Berger AG. In 2006, BIS AG active in whole Europe and North America had around 
23,000 employees and made a turnover of about EUR 1.6 billion. In terms of turnover, BIS AG is almost double the size of MCE AG but the EBIT-margin of 5 percent is not much higher than the one of MCE AG. (www.bis.bilfinger.com)

\subsubsection{ThyssenKrupp Xervon}

ThyssenKrupp Xervon - providing solutions for both maintenance and new projects - is a business division of the steel and technology company ThyssenKrupp with its headquarters in Düsseldorf. ThyssenKrupp Xervon has a workforce of 9,000 employees, so it can be seen as a major international service provider for the processing industry. The company is focused on Germany with 30 national locations and numerous subsidiaries and associated companies. Turnover in 2007 was EUR 387 million and EBIT-margin was around 4.5 percent. (www.thyssen.com)

\subsubsection{Siemens Industrial Solutions and Services}

The subdivision of Siemens Industrial Solutions and Services (Siemens I\&S), which is a competitor to MCE AG is Siemens Industrial Services including Engineering \& Construction, Logistics-Services, Maintenance and Inter Company Services. The whole Siemens I\&S group made a turnover of about EUR 8.82 billion and employed around 36,200 employees worldwide in 2006. The performance figures of 2006 show that EBITmargin was around 3.6 percent and in 2006 group profit margin was only around 2.5 percent. The financial figures of the market leading companies in this industry reveal that weak financial performance - EBIT smaller than 5 percent - is an industry-fixed phenomenon. (www.industrysolutions.siemens.com)

\subsubsection{Analysis of the Organization before DBAG Ownership}

Before analyzing the impact of DBAG on MCE AG, this chapter provides an analysis of organizational and corporate governance structures within MCE AG of the time before DBAG had acquired ownership and control. As mentioned above, MCE AG was set up in three business divisions, whereby two divisions - industrial services and personnel services - were profitable but the third division - facility management - was so unprofitable that it 
burned the profits of the two other divisions. One must wonder why an international PEcompany such as Andlinger and Company was maintaining this situation. Another question that should be raised is why Andlinger and Company decided - following their corporate philosophy - to let one of their Partners run the portfolio company as CEO instead of choosing an industry expert with more technical background. In general, it is not an uncommon strategy in Private Equity to let Senior Executives, who are Partner in PEfirms, manage their portfolio companies. The advantage lies in the fact that such a situation brings complete control over the company and its daily business. Additionally, there is no proof of management capabilities needed that Senior PE-Partners are able to run companies due to their executive industrial experience. Therefore, this situation can be regarded as another form of Operating Partnership. Yet, in such a highly technical industry with such a complex market, it is difficult to comprehend that Andlinger and Company had not chosen a CEO with experience in this specific industry. When analyzing the incentive system in MCE AG, it could be observed that there was a bonus system in the form of yearly performance based bonuses. The bonus-pay was based on an individual quantitative and qualitative evaluation as well as on the annual corporate performance. Anyhow, the described incentive system was not perfect and neither bad nor unusual. Another quite unusual fact is that there was no equity incentive system for top managers although MCE AG was in the hands of a professional and mature PE-firm. The chosen strategy of Andlinger and Company was primarily based on growth through acquisitions of relevant companies. Therefore, free cash flow was left in the company instead of paying dividends to the owners.

\subsubsection{Analysis of DBAG Ownership of MCE AG}

In April 2007, DBAG and its buyout funds became new majority owners of MCE AG by acquiring 75 percent of the shares from Andlinger and Company, which retained a 25 percent share in the company. Right after the acquisition Mr. Ludger Kramer became MCE AG's new CEO. Mr. Hermann Lutzenberger, the former CEO and Partner of Andlinger and Company, moved to the Supervisory Board. MCE AG is a typical portfolio company of DBAG since it is an international acting company with a market leading position in various industrial service industries and, additionally, financially underperforming. The multiple of a very low EBIT-margin was the reason for a comparably low purchase price. In October 
2008 DBAG became 100 percent shareholder of MCE AG by acquiring another 25 percent of shares from Andlinger and Partner.

\subsubsection{Value Creation by Changes in Corporate Governance Structure}

In this chapter the following topics are examined if and to what extent they were used by DBAG in the case of MCE AG:

- Evaluation and Change of Management

- Management Incentives

- Supervisory Boards

- Operating Partners and Industry Specialization

As mentioned above, DBAG brought in a new external CEO. Due to the fact that the former CEO represented the PE-firm Andlinger and Company, the CEO position had to be filled anyhow. Mr. Kramer, a top-manager with technical background, was asked by DBAG to step into the CEO position since he successfully restructured another company that used to be in a DBAG-fund. Further changes of management positions were not made since MCE AG was staffed with professional staff and managers. This theory of having top-employees was not directly examined by the new owners in the form of management evaluations, so one can assume that either the new CEO was satisfied with the $2^{\text {nd }}$ and $3^{\text {rd }}$ line management or DBAG followed the strategy to keep change as small as possible. The analysis of the new incentive system shows that DBAG made very big changes in remuneration programs on order to align interests. First, board members and division managers were asked to commit capital to the company in the form of an equity program. Besides the two board members - CEO and CFO - there were 10 division managers, whereby most of the divisions consisted of one commercial and one technical division leader. Altogether, they have committed about EUR 2 Mio, meaning that each of them was asked to commit at least EUR 100,000. After a successful sale of the company, these managers would receive their nominal capital invested times the percentage gain of DBAG, meaning the multiple of the sales price divided by the purchase price of MCE AG. Another part of the incentive system changed was the annual bonus system for the top managers. Annual bonuses were based on individual performance measured by the increase of the EBIT-margin and Free Cash Flow within the business unit each manager 
was responsible for. Also the reduction of net working capital and WACC of each business unit played a role for the annual bonus calculation. This program added a second strong incentive for a performance increase within each business unit. Concerning the topics Supervisory Board and Operating Partner, it can be stated that DBAG brought in a new Chairman of the Supervisory Board and two other Supervisory Board members all having senior industrial background. The Supervisory Board met quarterly and Mr. Egerer Chairman of the Board - met on a monthly basis with the two Executive Board members to review business progress. Nevertheless, DBAG did not provide an active Operating Partner acting as sparring partner for the Executive Directors. The analysis of changes by DBAG in the corporate governance structure of MCE AG reveals that this field of improvement was fully utilized and triggered a strong performance increase.

\subsubsection{Value Creation by Strategic and Operational Improvements}

In terms of value creation by strategic and operational improvements this chapter provides an analysis how strategy changes and operational improvement were implemented by DBAG. Speaking of a 100 day plan - explained theoretically in the literature review - in order to adjust the strategy of the portfolio company, DBAG did not follow this PEmethod. Nevertheless, strategic changes in the form of a new organizational setup were conducted by forming six new business units according to the clients industries listed below. Therefore the major business division of MCE AG, which was MCE Industrial Service, had to be split up into:

- Power Generation and Distribution

- Biotechnology, Pharmaceuticals, Fine Chemicals

- Plant Engineering and Steel Construction

- Mechanical and Apparatus Engineering

- Industrial Services

- Personnel Services, Engineering and Consulting

Instead of changing the strategy from the very beginning, the German PE-firm only observed how the loss-making business division Facility Management - with about 1,900 employees and EUR 355 million - was performing the following months after the 
acquisition. In case that the division does not improve its financial results, a sale of the whole division would be the only solution to the problem. In May 2008, MCE Facility Management was sold to the Finland-based YIT group - mainly active in facility management - for about EUR 55 million (http://www.yitgroup.com /services/extra/59089/59090). DBAG followed the strategy that MCE AG should only focus on its core competences, which are industrial service and maintenance. The Facility Management division formerly acquired from Mannesmann Anlagenbau was neither profitable nor did it fit into the core business of the MCE company. Another strategy followed and continued by DBAG was the strong inorganic growth of MCE AG by acquisitions of fitting companies in their markets. Therefore, DBAG left Free-Cash-Flow of EUR 70 million in the company instead of paying out dividends. This money should be used for further acquisitions. Since the MCE-management was qualified and since areas of potential operational improvement were recognized without outside help, DBAG did not focus on operational improvements in MCE AG. As mentioned above, there was no Operating Partner active in the company and no consulting companies for production improvements were hired.

\subsubsection{Analysis of Exit Scenario and Financial Improvements}

In November 2009, after a rather short holding period of about 2.5 years DBAG exited from the portfolio company MCE AG by selling the whole company - in the form of a share deal - to Bilfinger Berger, Germany`s biggest Construction Company and one of the main competitors in Industrial Services. As it was announced on the DBAG website, the strategic buyer paid DBAG several times the former purchase price that MCE AG was bought for from Andlinger and Company. There are several reasons for this high price that need to be explained in brief. First, the fact that MCE AG was one of the major competitors for Bilfinger Berger made the company a good fit for Bilfinger's strategy to become market leader. The added value of a strategic fit is expressed in the Acquisition Premium meaning that the Purchase Price was much higher than the book value of MCE AG. Secondly, by comparing the financial figures of 2006 - before DBAG ownership with the figures of 2008 it becomes clear that the financial performance of the company has ameliorated a lot. Since the MCE AG financial statement of 2009 is not available anymore, the financial figures of 2008 are used for comparison reasons. All figures beside 
turnover have increased as it is shown in figure No 24. The decrease of 11 percent in turnover was due to the sales of the business division Facility Management. Yet, considering that the sold division made EUR 355 million turnover, which would be one third of the aggregate turnover, one can conclude that the remaining divisions and newly acquired companies effected an increase of about 20 percent in turnover.

Most important is the doubling of the EBIT figure, since this is the real indicator of performance improvement. The increase of ROE was mainly due to the increase of EBIT but also due to the debt equity ratio of 20 to 80 , meaning that 20 percent of the MCE AG shares were paid to the former owner with bank debt being pushed down to the portfolio company after the acquisition process. Anyhow, this debt coming from DBAG was paid back by MCE AG within 2 years.

\begin{tabular}{|l|l|l|l|}
\hline T $€$ & $\mathbf{2 0 0 6}$ & $\mathbf{2 0 0 8}$ & Change in \% \\
\hline Turnover & $1,036,049$ & 919,478 & $191 \%$ \\
\hline EBITDA & 32,775 & 62,739 & $1037 \%$ \\
\hline Annual Surplus & 5,074 & 52,663 & $3 \%$ \\
\hline EBITDA-Margin & $3.2 \%$ & $6.8 \%$ & $3 \%$ \\
\hline Return on Sales & $1.7 \%$ & $4.9 \%$ & $22 \%$ \\
\hline Return on Equity & $20.7 \%$ & $42.8 \%$ & $472 \%$ \\
\hline Operating Cash Flow & 22,322 & 105,408 & $620 \%$ \\
\hline Free Cash Flow & 15,035 & 93,268 & $82 \%$ \\
\hline Employees & 8,072 & 6,655 & $7 \%$ \\
\hline Equity Ratio & $11.1 \%$ & $18.2 \%$ & \\
\hline
\end{tabular}

Figure No 24 MCE AG Key Performance Indicators 2006 and 2008

Not taking into account several issues such as committed equity of the management or Supervisory Board members of MCE AG, a rough calculation of DBAG gains and possible 
purchase of MCE AG is given a crack. The DBAG website states that they invested 12.9 million in MCE AG holding 18.8 percent, whereby the DBAG parallel funds held 78.2 percent of the company. Given this numbers and calculating 100 percent ownership, one may conclude that the 2007 purchase price of MCE AG was around EUR 70 million. Invest IQ, a PE-intelligence platform (http://www.invest-iq.com/DBAG-exits-MCE-AG) reports that DBAG has sold MCE AG to Bilfinger Berger for about EUR 350 million making a profit of EUR 43 million. This information leads to another conclusion. Having invested EUR 12.9 million and having gained EUR 43 million leads to the assumption that the value of MCE AG multiplied 3.33 times over the 2.5 years holding period. Given the sale price of EUR 350 million and a value multiple of 3.333, the suggested MCE purchase price of 2007 would be around EUR 105 million. The question of the exact purchase price of the company in 2007 remains open and can only be answered roughly. In terms of value creation, the most important information is the EBIT increase of almost 200 percent and the value multiplication of the MCE AG company of more than three times within about 30 months of DBAG ownership.

\subsection{Portfolio Company LEWA GmbH}

The LEWA Company - based in Leonberg close to Stuttgart in Germany - is a competence leading supplier of precision metering pumps, process-diaphragm pumps and customized metering systems for process engineering LEWA provides solutions for specific industries - ranging from basic engineering to process engineering pretesting and on-site start-up of the equipment. LEWA systems perform metering and process tasks to the maximum pressures experienced in the oil, gas and chemicals industries. LEWA also manufactures a range of pumps and systems for the pharmaceuticals industry as well as for the food and beverages industry. LEWA's core expertise includes high quality service and spare part distribution in after-sales, combined with experience in the international project management. Due to their innovative application capabilities and product engineering, LEWA can be seen as one of the global market leaders in the production of process diaphragm pumps. In 2009, the company - with 16 subsidiaries and a market presence in more than 90 countries worldwide - had a turnover of about EUR 130 million and employed around 700 people, whereof 400 are based in Germany. 


\subsubsection{History and Regional Presence}

LEWA was found in 1952 by the engineers Herbert Ott and Rudolf Schestag, who founded the "Ingenieurbüro LEWA" LEonberger WAsseraufbereitung (Leonberger Water Treatment). Soon they also customised metering pumps. Ten years later, in 1962 the company already had more than 100 employees. By then, their products were already sold in major parts of Europe and overseas in the US. Another ten years later, LEWA tripled revenues by developing a sophisticated diaphragm pump. In the early 1980s, the existing technology was replaced with a fundamentally new model range. By 1992, the company had developed a broad platform of process diaphragm pumps, systems technology and services. In 1998, one of the founders, Herbert Ott, died and the company was passed on to his wife and his daughters, who led the company with the help of management. After 50 years of existence LEWA was present in more than 60 countries worldwide and focused on technology advantage. In October 2005, the Ott family sold $100 \%$ of the company to DBAG.

\subsubsection{Analysis of the Organization before DBAG Ownership}

LEWA used to be a typical German mid size company that was family-run but with market leadership by applying the famous “German engineering” in a niche market. The company was always growing; yet, average sales increased only 3.5 percent per year from 1985 until 2005. The potential of the company with its outstanding products offered was not realized as it is often the case in family run mid size companies. This was, of course, expressed by a poor financial performance. It can be said that even though the company was a technical pioneer, the management was acting semi-professional in a way that it did not enhance growth strong enough.

\subsubsection{Analysis of DBAG Ownership of LEWA}

LEWA Gmbh serves as the case study example of value creation by active portfolio management, whereas MCE AG was the example of a rather passive investment. On the DBAG website, the following statement concerning active and entrepreneurial portfolio management can be found: 
"Our contribution: equity, time and expertise. For Deutsche Beteiligungs AG, entrepreneurial scope is the priority issue - the platform for its portfolio companies' profitability and long-term viability. Profitability is crucial, since it is the purpose and key driver of every successful enterprise. Long-term viability is equally important, since only a sustainable business model will ensure profitability over time. By focusing on these two goals, we automatically create the requisites for a profitable investment: aligning the interests of all the constituents involved.”(www.deutsche-beteiligung.de)

In fact, DBAG completely changed LEWA from a former family run business to highly profitable professionally managed PE-portfolio company. This change happened through various tools and methods that DBAG applied as active owner.

\subsubsection{Value Creation by Changes in Corporate Governance Structure}

In this chapter the following topics are examined if and to what extent they were used by DBAG in the case of LEWA:

- Evaluation and Change of Management

- Management Incentives

- Supervisory Boards

- Operating Partners and Industry Specialization

Since the LEWA management was not ideally set-up for the required growth and cultural changes that were planned by DBAG, Bernd M. Stütz, a very experienced top manager, became new CEO three months after the acquisition by DBAG. Additionally, some second line managers were exchanged. The empty positions were then filled with external managers, who - besides all other second and third line managers - became equity partners in the company. The fact that the new CEO was a big equity holder in the company contributed enormously to his credibility vis-à-vis the staff, since they liked the fact that there was - again after family ownership - someone at the top of the company, who was risking his own money in terms of decision-making employee expectation. The management of LEWA was backed through active work of the supervisory bodies in the form of on an advisory council. The managing director met with the advisory council on a monthly basis and reviewed business performance and targets. In terms of applying an 
active Operating Partner, DBAG did not see any need to do so since the new CEO became an extraordinary strong equity partner of DBAG and was an industry expert in addition.

\subsubsection{Value Creation by Strategic and Operational Improvements}

In terms of value creation by strategic and operational improvements this chapter provides an analysis how the various strategy changes and operational improvements were implemented by DBAG. After a few months of ownership when the new management was in place, the PE-firm together with the management clearly defined milestones for the targets of the following years. On the path to value growth, DBAG worked very closely with the new management team, so that an economically feasible forward-looking concept could be developed in 2005. One major action step in the value creation plan was the change of the whole corporate culture. That was done with a systematic strategic process called "LEWA FIT", whose individual components were spelled out in a 184-page document. With more than 100 highly skilled engineers the company had the potential for implementing change and realising the hidden performance potential. The "LEWA FIT" project was broken down to numerous smaller projects to change the working approach of employees. The most important tool to implement change was the establishment of an inter-company communication system across all levels. People started talking to each other much more than before, and that happened also across departmental lines. The CEO was a very good example by dedicating half of his time taking care of trainees and communicating with employees. In order to improve operational processes within the company, "profit teams" were created in the beginning of the year 2006. Two or three people of each team looked at processes and asked how to make them more efficiently and, in addition to that, certain types of costs were analysed by them asking how to reduce them. Therefore, frequent brainstorming sessions were planned in order to build a corporate culture of open communication. This should allow becoming more creative and responsible. Besides revealing cost-cutting potentials, the company gained a lot of innovative ideas from the teams. The production and assembly teams became fully responsible for a given order from assorting the parts and assembling the components to testing the finished product. Another part of LEWA FIT and area of improvement was the foundation of the LEWA Academy, which became a simple but effective organisational superstructure for training courses and seminars. Before the existence of the LEWA 
academy there were five courses offered in the company, and that has changed to over 50 courses. Every employee received a "Quality Passport" certifying every course he or she has visited. Employees then receive a bonus after they have earned a certain number of credentials. Of course, one of the main strategic goals is growth, which can either be reached by organic sales increase or by inorganic growth following an acquisition and cooperation strategy. DBAG has enforced the internationalization of the sales organisation of LEWA by the transfer of proprietary technology to new fields of application. LEWA has, therefore, expanded its presence in global markets and became more aggressive in pursuing projects. They started offering their know-how in markets not served in the past and communicate their proposition to potential users in those markets. Originally, LEWA grew from the oil, gas and chemical markets, but new markets - such as the pharmaceutical, plastics and cleaning agent industries - have been added since 2006 when DBAG became active as owner. Besides these new markets, the food and beverage industries have also become new clients. During the time of DBAG ownership, LEWA was also active in M\&A and strategic cooperation by acquiring a company in Norway and in North America. Additionally, the company established joint ventures in Asia. LEWA increased internal R\&D expenditures considerably and developed new products. After all, three major improvements could be realised from 2005 until 2009. First, LEWA used to be a pump manufacturer and became a solutions provider, which changes the client relationship tremendously since the solution provided becomes irreplaceable. Secondly, the performance of the company improved significantly in terms of financial results. The third major accomplishment was the market entry in additional business areas.

\subsubsection{Analysis of Exit Scenario and Financial Improvements}

In September 2009 after four years of impressive growth, LEWA became an attractive take-over target and was sold for a very profitable price to an ideal strategic investor. After many negotiations, the decision was made to sell the company to the management's preferred partner, which was the Japan-based Nikkiso Co., Ltd. The new owner creates an optimal access to the new markets for LEWA. The profitable realisation of the exit of LEWA was due to the performance improvement enhanced by DBAG and the new LEWA management. The company increased sales, streamlined its managerial and workflow organisation and became considerably more profitable. During the time of DBAG- 
ownership, sales growth averaged 15 percent annually in contrast to the 3.5 percent annual growth in the past. Earnings, formerly reaching less than five percent, impressively rose up to more than 20 percent per year. Within four years, turnover more than tripled from EUR 42 million in 2005 to EUR 145 million in 2009 as it is clearly shown in figure No 25. The grey coloured area in the figure is the time of family ownership and the blue coloured area is the ownership era of DBAG. One can easily observe that profits rose accordingly from around EUR 2 million per year in 2005 to around EUR 30 million in 2009. DBAG acquired $100 \%$ of LEWA in 2005, whereby 34.4 percent were held by co-investment funds and 50 percent by Quadriga Capital. Since numbers are not available in this case, one can only assume that DBAG made an extremely profitable deal with the sale of LEWA.

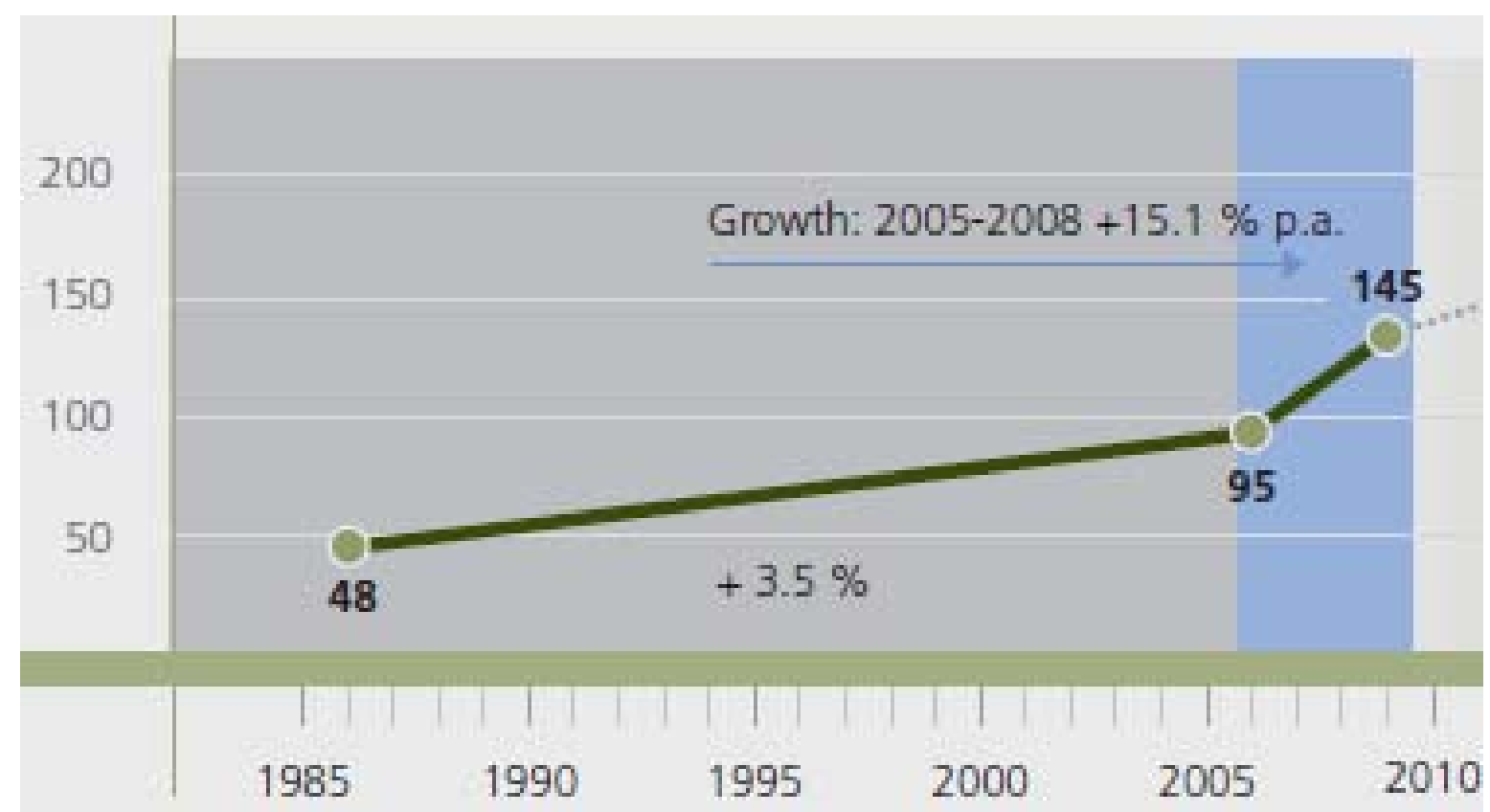

Figure No 25: LEWA: Development of Sales in Million EUR

\subsection{Analysis of the Difference in Applied Portfolio Management Approaches}

Before going into details about the differences in applied portfolio management, it has to be mentioned that due to the different corporate size of the two case study companies, availability of information was not equal. Neither the complexity of the websites nor the press coverage of businesses and deal activities are comparable. LEWA, as a small to mid size company with family background does not disclose much information about 
management and organizational issues. MCE AG, in contrast, had a comprehensive website and press coverage was very sufficient for the case study purpose.

In the comparison between the two different portfolio management approaches applied by the PE-firm DBAG, one can observe that there are several key facts distinguishing these two investments. The first and most important difference between the two different portfolio companies is company size and, therefore, level of professionalism. MCE AG once integrated in a concern structure, then owned by an American PE-firm - is a much company than normal Austrian mid size standards. In contrast to MCE AG, LEWA used to be a family run business significantly smaller in terms of turnover and employees. Secondly, LEWA is also very different from MCE AG in terms of strategy and process driven efficiencies, which means that the upside potential in terms of management and process improvement can be relatively higher within LEWA. These explained differences might be the reason why DBAG - as one single owner of various companies - acts differently on each investment. In the case of MCE, value was created mainly by adjusting corporate governance and incentive systems. The new CEO in MCE AG was important but not so much the main driver for growth than the new CEO was in the case of LEWA. The main value-driver in MCE AG was the equity incentive system for managers and the successful sale of the Facility Management division. In the case of LEWA, corporate governance changes such as the hiring of new top-managers with the possibility of equity investment played a minor role in terms of value creation. The major factor of value creation in LEWA was operational improvement and strategic change. Of course, one can argue that the change management project "LEWA FIT" could not have worked without the right people at the top. Yet, without DBAG as new owners, managers would not have been exchanged and neither be that motivated by attractive equity incentive systems as it was the case. A good management team alone is not enough, and a change of corporate culture hardly works without the right people. So, this seems like a circular cause and consequence question. When analyzing the case of MCE AG, it can be observed that the professional management was already there, and no operational improvement program motivated by DBAG took place. In my opinion, the potential in MCE AG was much higher than what was realised. Increased process efficiency, successful cost cutting, technical innovation driven by a culture of communication, new markets, new internal training academy and many other positive results are the result of a successfully implemented change project. From general business knowledge and many corporate legends, one might 
know that also large international and stock listed companies have undergone such cultural and process change programs several times. The question remains why DBAG did not make use of strong operational improvement programs in the case of MCE AG. DBAG invested in LEWA in 2005 and in MCE in 2007, so there is no positive learning curve explaining why several actions taken by DBAG-ownership within LEWA were not applied in the case of MCE AG. The German PE-firm DBAG is a mature PE-company including long history and stock listing. The company claims to be very active and hands-on towards their investments, which is proven by the case of LEWA. Former investments and the example of MCE AG reveal that they are - in some cases - rather limited to be rather pure capital providers with good incentive systems. The fact that the top managers of MCE AG - one of the largest DBAG-portfolio companies ever - have never seen any DBAG board member inside MCE AG proves a certain “banker’s attitude”.

The literature review of this work suggests many different and effective triggers to actively create value in portfolio companies. Many of the explained triggers are not mentioned in the case study, since they are not applied by DBAG. The PE-firm of the case study claims to have Operating Partners that are active in the portfolio companies. Reality shows that they are only sitting in the advisory board not covering any of the tasks Operating Partner would do. Another trigger to ameliorate corporate performance and the constellation of the management team is management evaluation. This tool often applied in Anglo-Saxon and Scandinavian cultures is not very common in German-speaking countries, and probably not accepted from a cultural perspective. The famous 100 day plan is another tool that is rather limited to Anglo-Saxon PE-firms. Internet research shows that efficiency plans used during the first 100 days after the acquisition are not very much applied by PE-firms in Central Europe. 


\section{CONCLUSION}

The main purpose of this thesis is the theoretical analysis of the concept of value creation in portfolio companies in the context of Private Equity. Based on previous research that was carefully analyzed in the literature review section, the research question was compiled claiming that firms active in Private Equity create more value when following an active portfolio management model towards their investments. In order to show how various corporate governance and operational levers could be applied in real-life companies, a case study was conducted comparing two different portfolio management models applied by the same PE-firm.

The literature study providing a basic introduction into Private Equity and covering most recent studies on value creation in Private Equity reveals that there are many different ways to generate value. Literature first differs between value creation by financial leverage and operational value creation measuring how much value was created beside leverage effect. This work with a focus on value creation apart from the financial leverage looked at two different areas where value can be triggered in a portfolio company.

Value creation by changes in the corporate governance model is not new in Private Equity and has be done by most of the large and mature PE-firms. Literature and the case study approves that the equity incentive system is one of the main triggers of value creation in Private Equity. In the case of MCE AG, the equity incentive for top managers was probably the main driver of performance improvement. Also the exchange of CEOs is a very common method to show that ownership has changed and new strategies are pursuit with new top managers.

The new trend of these days is generating value through operational improvement, which requires a combination of various factors. First, the setup of a PE-firm reveals how the company thinks. DBAG seems to be a typical investment banking driven “old-school” PEcompany. With a look at the bios of the employees, one knows that there is hardly anyone with operational or consulting background. More than 90 percent have banking, finance, M\&A or legal background. That explains the lacking capacity in operational improvements and the only formal cooperation with Operating Partners.

Having an industrial focus where to invest and cooperating with Operating Partners is another crucial point as literature suggests. DBAG has developed a narrow investment 
focus for the last decades and is a well known PE-player in the German mid market of industrial, chemical, automotive supply and industrial solution companies. This focus explains the ability to identify underperforming targets with value creation potential. Therefore, Operating Partners are very helpful - as an illustrative story in the literature review shows - and DBAG is able to use a tight industrial network in Germany. Nevertheless, the systemic use of Operating Partners in portfolio companies and the ability to accurately determine the potential value creation and the level of difficulty associated with each possible operational improvement have not been fully cultivated by DBAG.

In the case of LEWA, strategy change, operational improvement by efficiency increase, new markets, new products and other improvements could be implemented. Yet, the question remains how many of the change initiatives directly came from DBAG and what was initiated by the LEWA-management. In either case, the example shows that DBAG is aware of the new trend towards operational improvements in Private Equity. Since selling the companies with an adequate profit is the ultimate goal of the PE-business model, and both companies, MCE AG and LEWA, were exited very successfully, it has to be acknowledged that DBAG did a good job in finding the right buyers and negotiating good prices in a difficult economic situation. In general, it can be concluded that under the new economic and financial environment, the ability to create and execute operational improvement strategies is becoming Private Equity's most important competitive advantage (Matthews and Howland, 2009). Literature (IESE/BCG, 2008) also claims that the most successful PE-firms seem to be those that have gone the farthest in implementing a new, more sophisticated model of value creation to develop what may be sustainable competitive advantages. Operational value creation is a product of engaged ownership.

The literature review and case study approach in this comprehensive work is limited in various dimensions and can only be understood as an attempt to review existing knowledge and reveal possible ways of applications in portfolio companies. Further research could be done by enlarging the study to a sample of PE-companies and portfolio companies large enough to draw statistical significant conclusions. Especially, with the use of PEintelligence data, it would be interesting to analyze correlations between IRR performance - on either transaction or fund level - with a classification of active and passive investors in Private Equity. 


\section{BIBLIOGRAPHY}

ACE Business Services; http://www.acebuiss.com/fund/PE/structure.htm; last visited on April 28 ${ }^{\text {th }}, 2010$

Acharya V.V.; Hahn M. and Conor K. (2009): "Corporate Governance and Value Creation: Evidence from Private Equity" CEPR Discussion Papers 7242, C.E.P.R. Discussion Papers.

Achleitner A.K. et al. (2010):”Value Creation Drivers in Private Equity Buyouts: Empirical Evidence from Europe”, Journal of Private Equity, Spring 2010

Anders G. (1992): “The Barbarians in the Boardroom.” Harvard Business Review, JulyAugust 1992, pp. 79-87.

Anderson J. (2007): “For Private Investment, the Party Isn’t Over,” New York Times, October 10, 2007.

Andrade G., and Kaplan, S.N. (1998): "How Costly is Financial (Not Economic Distress)? Evidence from Highly Leveraged Transactions That Became Distressed”; Journal of Finance, 53(5): 1443-94.

Baker G. P. and Wruck K. H. (1989): “Organizational Changes and Value Creation in Leveraged Buyouts: The Case of the O.M. Scott \& Sons Company” Journal of Financial Economics, 25 (1989), pp. 163-190.

Baker G.P. and Smith G.D. (1998): "The New Financial Capitalists: Kohlberg Kravis Roberts and the Creation of Corporate Value”, Cambridge, MA: Cambridge University Press 
Barry C; et al. (1990): "The role of venture capital in the creation of public companies: evidence from the going-public process” Journal of Economics, 27, p. 447-471

Becht M., Bolton P. and Röell A. A. (2002): “Corporate Governance and Control”; ECGI Finance Working Paper No. 02/2002

Brick I. E. and Chidambaran N. K. (2007): “Board Meetings, Committee Structure, and Firm Performance” Social Science Research Network Working Paper; Available at SSRN: http://ssrn.com/abstract=1108241; last visited on March $16^{\text {th }}, 2010$

Bundesverband Deutscher Kapitalbeteiligungsgesellschaften, BKV Statistics (2008): http://www.bvkap.de/media/file/300.20090308_BVK_Jahresstatistik_2009_final.pdf; last visited on April 15 ${ }^{\text {th }}, 2010$

Campbell A., Goold M. and Alexander M. (1995): “Corporate Strategy: The Quest for Parenting Advantage.” Harvard Business Review, March-April 1995, pp. 120-132.

Capizzi V. (2005): “Leveraged Acquisitions: Technical and Financial Issues”; in Structured Finance; Springer, Heidelberg,

Citigroup Global Markets Equity Research, "European Portfolio Strategist,” November 16, 2006.

Covitz D. and Liang N. (2002): “Recent Developments in the Private Equity Market and the Role of Preferred Returns”; Board of Governors of the Federal Reserve System. Washington, DC 20551. 
Cornelli F. (2008): "Private equity and corporate governance: do LBOs have more effective boards?” World Economic Forum, Globalization of Alternative Investments Working Papers Volume 1; The Global Economic Impact of Private Equity Report 2008.

Cotter J. F. and S.W. Peck: “The Structure of Debt and Active Equity Investors: The Case of the Buyout Specialist.” Journal of Financial Economics, 59 (2001), pp. 101-147.

De Angelo H., DeAngelo L. and Rice E. M. (1984): "Going Private: The Effects of a Change in Corporate Ownership Structure”, Midland Corporate Finance Journal, 11-13.

Demiroglu C. and Christopher M. (2010): “The Role of Private Equity Group Reputation in LBO Financing”, Journal of Financial Economics, March 2010

Deutsche Beteiligungs AG Website: www.deutsche-beteiligung.de; last visited on May $2^{\text {nd }}, 2010$

Diller C. and Kaserer C. (2004): "What Drives Cash Flow Based European Private Equity Returns?” CEFS Working Paper No. 2004-01

European Commission; Expert Group Report on Private Equity, June 2006; http://ec.europa.eu/internal_market/investment/docs/other_docs/reports/equity_en.pdf; last visited on April 15 ${ }^{\text {th }}, 2010$

EVCA (2008): “Final Performance Figures” http://www.evca.eu/knowledgecenter/statisticsdetail.aspx?id=454; last visited on April $15^{\text {th }}, 2010$ 
Fenn, G. W.; Liang, N. et al. (1996): "The Economics of the Private Equity Market" Federal Reserve Bulletin Board of Governors of the Federal Reserve

Fenn G.W. and Prowse S. (1997): “The Private Equity Market: An Overview. Financial Markets, Institutions \& Instruments”, volume 6, number 4. Blackwell Publishers

Financial Dictionary: http://financial-dictionary.thefreedictionary.com/Private+Equity

Gompers P. and Lerner J. (1999): "An analysis of compensation in the U.S. venture capital partnership" Journal of Financial Economics

Gompers P.A. (1996): "Grandstanding in the venture capital industry"; Journal of Financial Economics, vol. 42(1), pages 133-156

Gottschalg O. and Phalippou L. (2005): "Performance of Private Equity Funds"; University of Amsterdam - Business School; Tinbergen Institute; HEC Paris Management; EFA 2005 Moscow Meetings

Groh A. and Gottschalg O. (2008): “The Opportunity Cost of Capital of US Buyouts”; National Bureau of Economic Research Working Paper No. 14148

Guest (2009): “The Impact of Board Size on Firm Performance: Evidence from the UK”; The European Journal of Finance, Vol. 15, Issue 4.

Guo S., Hotchkiss, E. S. and Song W. (2007): “Do Buyouts (Still) Create Value?”; Journal of Finance, Forthcoming. Available at SSRN: http://ssrn.com/abstract=1009281; last visited on May $3^{\text {rd }}, 2010$ 
Hass W. J. and Pryor S. G. (2009): What Public Companies Can Learn from Private Equity: Pursue the Value Journey; The Journal of Private Equity Summer 2009, Vol. 12, No. 3: pp. 20-28

Heel J. and Kehoe C. (2005): "Why some private equity firms do better than others"; The McKinsey Quarterly 2005, Number 1.

Helfat C.E. and Bailey E.E. (2005): "External Succession and Disruptive Change: HeirsApparent, Forced Turnover and Firm Performance”; Strategic Organization, Vol. 3, No. 1.

Heuskel D., Beckmann P. and Fechtel A. (2006): “Managing for Value: How the World's Top Diversified Companies Produce Superior Shareholder Returns”; BCG publication; www.bcg.com/documents/file14912.pdf; last visited on April 10 ${ }^{\text {th }}, 2010$

Hite G. And Vetsuypens M. (1989), "Management buyouts of divisions and shareholder wealth", Journal of Finance, Vol. 44 No.4, pp.953-70

Ibbotson, R. G., J. L. Sindelar, et al. (1988): "Initial Public Offerings"; Journal of Applied; Corporate Finance 1: 37-45.

Invest IQ Website: http://www.invest-iq.com/DBAG-exits-MCE-AG; last visited on April $23^{\text {rd }}, 2010$

Jelic R., Saadouni B. and Wright M. (2005): “Performance of private to public MBOs: The role of venture capital”; Journal of Business Finance \& Accounting 32(3-4), 643-682

Jensen M. C. (1986): “Agency Costs of Free Cash Flow, Corporate Finance, and Takeovers.” American Economic Review, Vol. 76, No. 2 (1986), pp. 323-329. 
Jensen M. C. et al. (2006): “Morgan Stanley Roundtable on Private Equity.” Journal of Applied Corporate Finance, Vol. 18, No. 3 (2006), pp. 8-37.

Kaplan S. and Stromberg P. (2008): “Leveraged Buyouts and Private Equity”, Working Paper 14207; http://www.nber.org/papers/w14207; last visited on April 18 ${ }^{\text {th }}, 2010$

Kaplan S. and Schoar A. (2005):“Private Equity Performance: Returns, Persistence, and Capital Flows.” Journal of Finance, Vol. 60, No. 4 (2005), pp. 1791-1823.

Kaplan S: (1989): “The effects of management buyouts on operations and value”, Journal of Financial Economics 24, 217-254.

Kaufman A. and Englander E.J. (1993): “Kohlberg Kravis Roberts \& Co. and the Restructuring of American Capitalism” The Business History Review, Vol. 67, No. 1, pp. $52-97$.

Klier D., Welge M. and Harrigan K. (2009): “The Changing Face of Private Equity: How Modern Private Equity Firms Manage Investment Portfolios” The Journal of Private Equity Fall 2009, Vol. 12, No. 4: pp. 7-13

Klier D (2009): “Managing Diversified Portfolios: What Multibusiness Firms Can Learn from Private Equity”, Contributions to Management Science; Heidelberg: Springer

Kravis Henry R. Keynote Speech, Private Equity Analyst Conference, New York, 2004.

Lawler E.E.; Finegold D.L.; Benson G. and Conger J.A. (2002): “Corporate Boards: Keys to Effectiveness”; Organizational Dynamics; Volume 30, Issue 4, Pages 295-380 
Lerner J. (1994): "Venture capitalists and the decision to go public"; Journal of Financial Economics, vol. 35(3), pages 293-316

Lerner J., Schoar A. and Wong W. (2007): "Smart Institutions, Foolish Choices: The Limited Partner Performance Puzzle”; Journal of Finance, American Finance Association, vol. 62(2), pages 731-764

Leslie P. and Oyer P. (2009): “Managerial Incentives and Value Creation: Evidence from Private Equity”; EFA 2009 Bergen Meetings Paper

Liechtenstein H., Meerkatt H.; Prats M.; $M^{\text {a }}$ Julia et al. (2008): "The advantage of persistence: How the best private-equity firms "beat the fade"'", Ed. IESE; The Boston Consulting Group, Inc.

Liechtenstein H. and Meerkatt H. (2010): "Time to engage-or fade away. What all owners should learn from the shakeout in private equity", Ed. IESE; The Boston Consulting Group, Inc.

Listed Private Equity Index: www.lpx.ch; last visited on April 10 $0^{\text {th }}, 2010$

Ljungqvist A. and Richardson M. (2003): "The cash flow, return and risk characteristics of private equity," NBER Working Papers 9454, National Bureau of Economic Research, Inc.

Loos N. (2005): "Value Creation in Leveraged Buyouts"; Dissertation No. 3052, University of St. Gallen; Graduate School of Business Administration, Economics, Law, and Social Sciences (HSG) 
Matthews G., Bye M. and Howland J. (2009): “Operational Improvement: The Key to Value Creation in Private Equity”, Journal of Applied Corporate Finance, Vol. 21, Issue 3, pp. 21-27

McKinley C. (2007): “CalPERS Adopts New Asset Allocation Mix-Equalizes U.S. International Stocks; hikes private equity, real estate,” http://www.calpers.ca.gov/index.jsp?bc=/about/press/pr-2007/dec/calpers-adopts-newasset-allocation-mix.xml; last visited on April $3^{\text {rd }}$, 2010

Mehta V. (2004): "Principal-Agent Issues in Private Equity and Venture Capital”, Wharton Research Scholars Journal; University of Pennsylvania.

Muscarella C.J. and Vetsuypens, M.R. (1990), "Efficiency and organizational structure: a study of reverse LBOs", Journal of Finance, Vol. 45 pp.1389-413

Nikoskelainen E. and Wright M. (2007): “The impact of corporate governance mechanisms on value increase in leveraged buyouts”. Journal of Corporate Finance, 13, issue 4, pp. 511-537

Private Equity Media Website: http://www.peimedia.com/pei300; last visited on April $19^{\text {th }}, 2010$

Pappas G., Allen I. and Schalock A. (2009): "Why PE Firms are Restructuring (and Not Just Their Portfolio Companies”; The Journal of Private Equity Fall 2009, Vol. 12, No. 4: pp. 22-28

Palepu K.G. (1990): “Consequences of Leveraged Buyouts.” Journal of Financial Economics, 27, pp. 247-262 
Peyer U. C. and Loderer, C. F. (2001): “Board Overlap, Seat Accumulation, and Share Prices” (September 5, 2001). EFMA 2001; Lugano Meetings

Pratt J. and Zeckhauser R. (1985): "Principals and Agents: the Structure of Business”, Harvard Business School Press

Stalk G. Jr., Evans, P., and. Shulman, L. E. (1992): “Competing on Capabilities: The New Rules of Corporate Strategy”, Harvard Business Review, March 1992.

Sundgren S. and Wells M. T. (1998): "Larger Board Size and Decreasing Firm Value in Small Firms"; 48. Journal of Financial Economics 35-54 (1998)

Tenbruck F. (1981):. „Emile Durkheim oder die Geburt der Gesellschaft aus dem Geist der Soziologie“; Zeitschrift für Soziologie 10:333-50.

Yermack D. (1996) "Higher market valuation of companies a small board of directors”, Journal of Financial Economics 40, 185-202.

YIT group website: http://www.yitgroup.com/services/extra/59089/59090; last visited on March $25^{\text {th }}, 2010$

Zong L. (2005) "Governance Lessons from the Private Equity Industry", The Journal of Private Equity, Vol. 9, No. 1, pp. 63-66 